UNIVERSIDADE DE SÃO PAULO

FACULDADE DE ECONOMIA, ADMINISTRAÇÃO E CONTABILIDADE DEPARTAMENTO DE ECONOMIA

\title{
CLUSTERS E A INDÚSTRIA LIGADA À ÁREA DA SAÚDE EM RIBEIRÃO PRETO.
}

\author{
LUCIANA OLIVEIRA TELLES
}

ORIENTADOR: PROF. DR. RUDINEI TONETO JUNIOR

SÃO PAULO 
Reitor da Universidade de São Paulo

Prof. Dr. Adolpho José Melfi

Diretor da Faculdade de Economia, Administração e Contabilidade Prof. Dr. Eliseu Martins

Chefe do Departamento de Economia

Carlos Roberto Azzoni 
UNIVERSIDADE DE SÃO PAULO

FACULDADE DE ECONOMIA, ADMINISTRAÇÃO E CONTABILIDADE

DEPARTAMENTO DE ECONOMIA

\title{
CLUSTERS E A INDÚSTRIA LIGADA À ÁREA DA SAÚDE EM RIBEIRÃO PRETO.
}

\author{
ALUNO: LUCIANA OLIVEIRA TELLES \\ ORIENTADOR: PROF. DR. RUDINEI TONETO JUNIOR
}

Dissertação apresentada ao Departamento de Economia da Faculdade de Economia, Administração e Contabilidade da Universidade de São Paulo para a obtenção do título de Mestre em Economia.

SÃO PAULO

2002 
Telles, Luciana Oliveira

Clusters e a indústria ligada à saúde em Ribeirão Preto /

Luciana Oliveira Telles. - São Paulo: FEA/USP, 2002. p. 84

Dissertação - Mestrado

Bibliografia

1. Clusters industriais 2. Estudos setoriais 3. Economia regional I. Faculdade de Economia, Administração e Contabilidade da USP.

CDD -338.9 
Para Dalmo, Lúcia,

Mila e Lucas. 


\section{Agradecimentos}

Agradeço a todas as pessoas que estiveram envolvidas, direta ou indiretamente, na realização deste trabalho.

Ao Prof. Rudinei Toneto, meu orientador, pela sugestão do tema, pelas considerações e comentários e, principalmente, pela paciência e amizade.

A todos os professores do IPE que ministraram os cursos de 1998/99 pela amizade e pela dedicação às disciplinas do mestrado. Especialmente, ao Prof. Paulo Picchetti, pela consideração com os alunos no período em que foi coordenador da pós-graduação e à Prof $^{a}$. Elizabeth Farina, com quem havia iniciado o trabalho de dissertação, pela disponibilidade e atenção. Aos funcionários, por todas as gentilezas e dedicação em resolver os problemas cotidianos dos alunos, em especial, à Valéria, Cris e à Beth. Aos amigos do IPE, por todos os momentos que passamos juntos.

Aos professores da FEA - Ribeirão Preto pela formação na graduação e pelo incentivo na conclusão deste trabalho, em especial ao professores Reynaldo Fernandes e Francisco Anuatti e à Andréia Maciel, secretária do departamento de economia. Aos amigos, familiares e colegas de trabalho pela contribuição com textos e sugestões, pela convivência e pela amizade: Maurício, Guilherme, Felipe, Wilma, Fabíola, Nena, Dalmo, Lúcia, Ludmila e Lucas. 


\title{
Resumo
}

O trabalho analisa a indústria de equipamentos médicos, hospitalares e odontológicos em Ribeirão Preto usando a literatura dos clusters como referencial teórico. O levantamento do perfil das empresas locais do setor e do arranjo produtivo local foi realizado através de pesquisa de campo com as empresas locais e com os laboratórios das faculdades pertencentes à Universidade de São Paulo. Com isto, espera-se conhecer melhor o que são as empresas deste setor no município e espera-se poder delinear as possibilidades do desenvolvimento de um cluster na área de equipamentos médicos, hospitalares e odontológicos entre as empresas do município como um meio de alavancar o crescimento das empresas e dinamizar a economia local, aproveitando-se da produção local e do aparato institucional existentes.

\begin{abstract}
This work analyses the industry of medical equipments in the city of Ribeirão Preto using clusters literature as theoretical reference. The studies of the characteristics of the local firms and its local arrangements were realized by a research with these firms and with the laboratories of the University of São Paulo. We expect to contribute to the knowledge of this industrial sector in this city and also to contribute to draw the possibilities of development of a medical equipment cluster as a mean to boost the local industry and the local economy, taking advantage of the existing production and the institutional apparatus.
\end{abstract}




\section{Índice}

Introdução

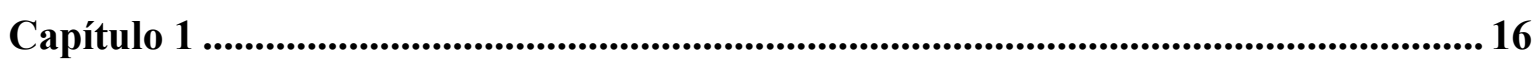

Concentração Geográfica das Firmas, Clusters e Sistemas de Inovação. ........................ 16

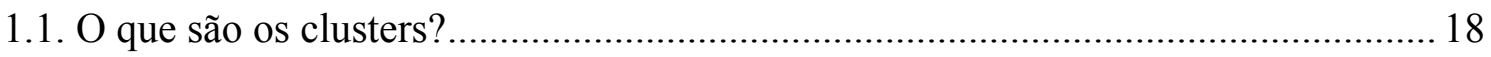

1.2. De onde vem as vantagens da concentração geográfica das firmas? ....................... 21

1.3. O que determina a existência de um cluster numa região específica?...................... 23

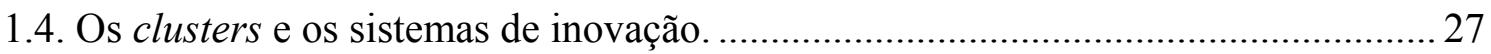

1.4.1 Algumas considerações sobre o processo inovativo. ........................................ 27

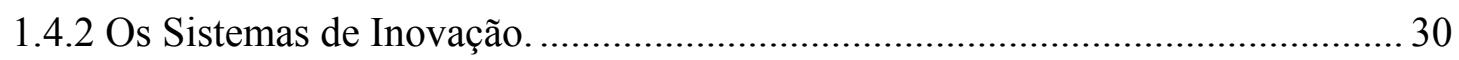

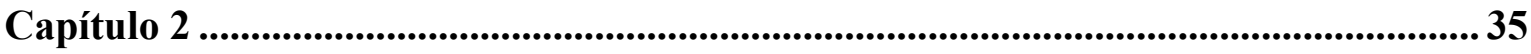

A Indústria de Equipamentos Médicos, Hospitalares e Odontológicos (EMHO)........... 35

2.1. A indústria de equipamentos médicos, hospitalares e odontológicos no Mundo..... 35

2.2. A indústria de equipamentos médicos, hospitalares e odontológicos no Brasil....... 38

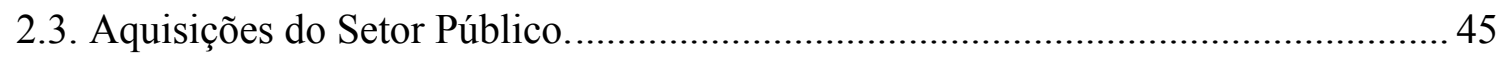

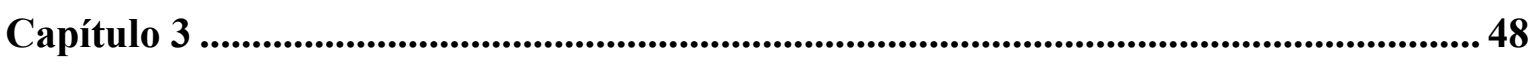

A Indústria Ligada à Área da Saúde em Ribeirão Preto................................................. 48

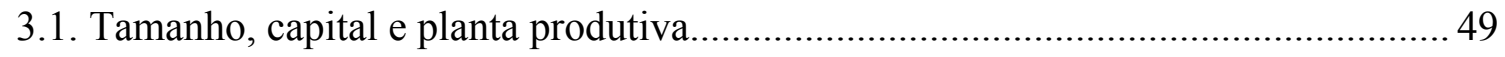

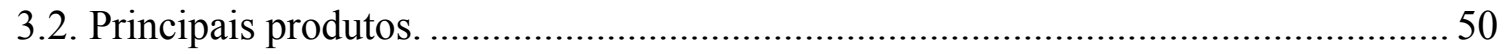

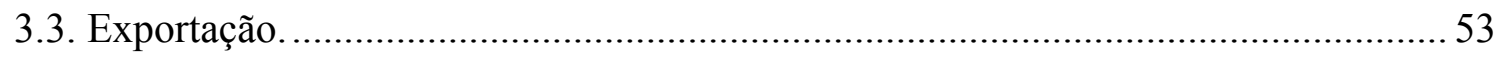

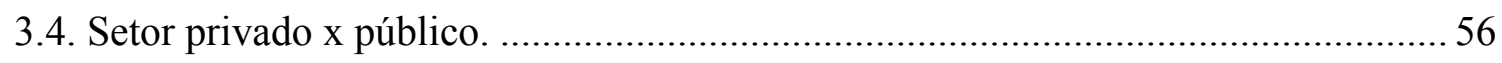

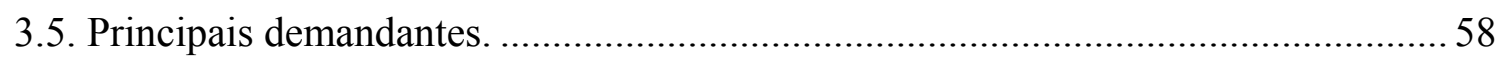

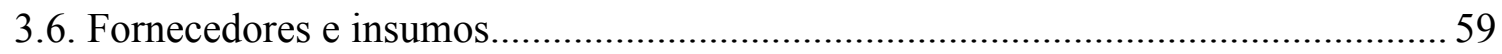

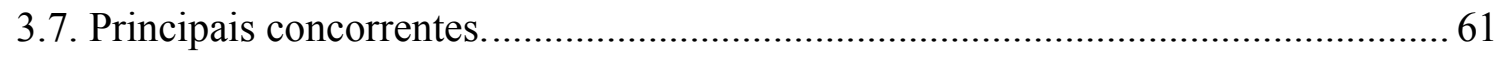

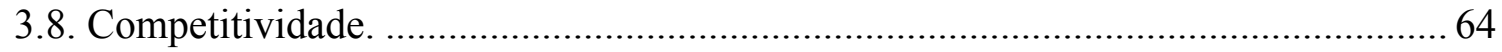

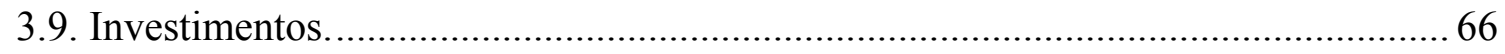




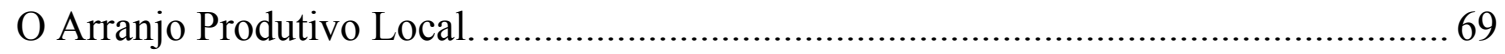

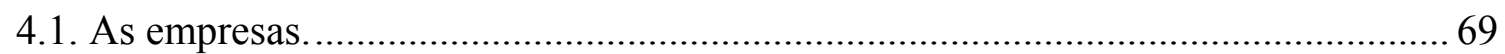

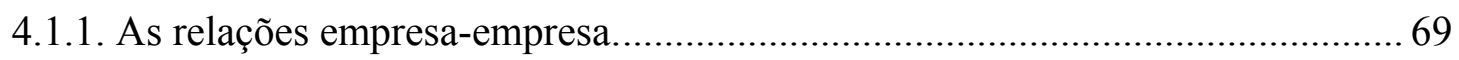

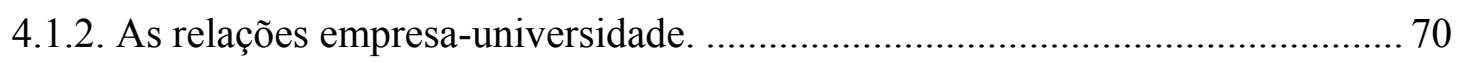

4.1.3. As relações empresa - sindicato de fabricantes. ................................................ 71

4.1.4. As relações empresa - escolas técnicas............................................................. 72

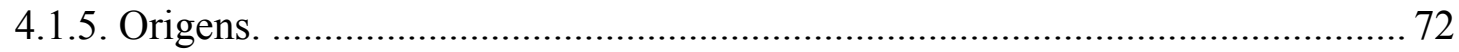

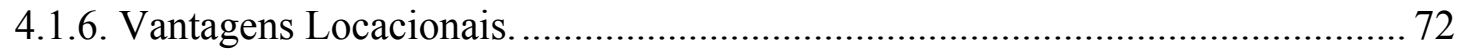

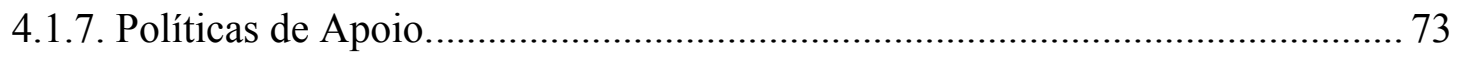

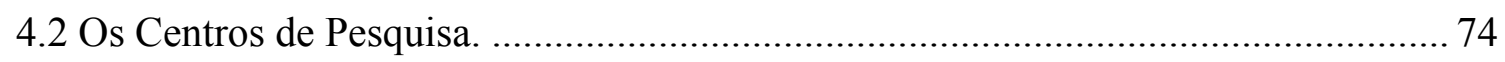

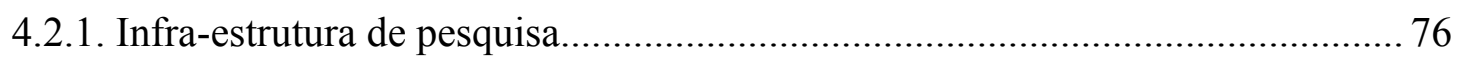

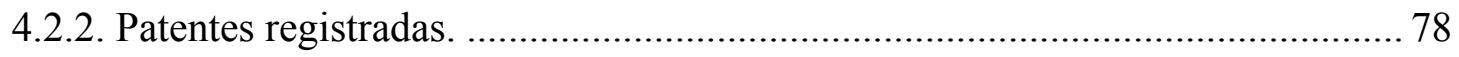

4.2.3. Potencial para desenvolvimento de produtos. .................................................... 79

4.2.4. Experiências de trabalho em parceria com o setor privado.............................. 81

4.2.5. Formas possíveis de relação com o setor privado. ........................................... 82

4.2.6. Importância dos seguintes instrumentos para o desenvolvimento tecnológico: 1) incubadora de empresas, 2) fundo de capital de risco e 3) auxílio na busca de recursos.

ANEXO I - Questionário Enviado para as Empresas da Área da Saúde do Município

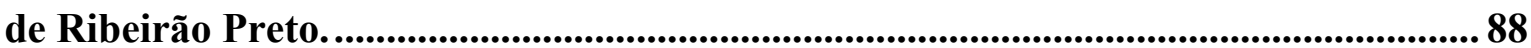

ANEXO II - Roteiro de Informações Enviado para as Unidades de Ensino da Universidade de São Paulo campus de Ribeirão Preto................................................96 


\section{Índice de Tabelas}

\section{Capítulo 2}

Tabela 2.1. Evolução do Produto (mil US\$ 1985) e do Pessoal Ocupado da Indústria de EMH..... 40

Tabela 2.2. Dados de Faturamento e Pessoal Ocupado da Indústria de Equipamentos Médicos .... 41

Tabela 2.3. Indicadores Econômicos da Indústria Paulista de Equipamentos Médicos (1996) ....... 42

\section{Capítulo 3}

Tabela 3.1. Participação do Setor Saúde no Emprego - Ribeirão Preto 1998 .................................... 48

Tabela 3.2. Principais Produtos da Indústria da Saúde em Ribeirão Preto ......................................... 50

Tabela 3.3. Principais Linhas de Produtos e Participação no Faturamento......................................... 52

Tabela 3.4. Distribuição do Faturamento entre Mercado Interno e Externo ...................................... 54

Tabela 3.5. Principais Dificuldades para Entrar no Mercado Externo ............................................... 56

Tabela 3.6. Distribuição do Faturamento entre Setor Público e Privado ........................................... 57

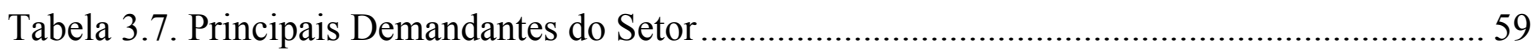

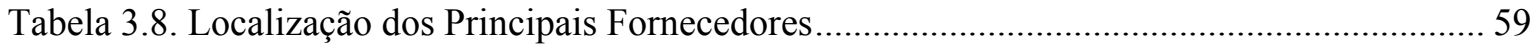

Tabela 3.9. Participação dos Insumos Importados no Gasto Total com Insumos ............................. 61

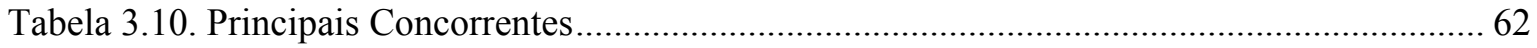

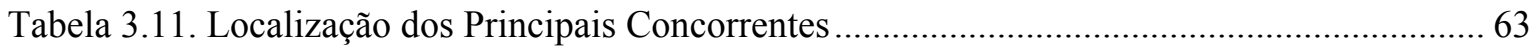

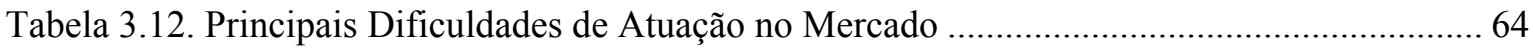

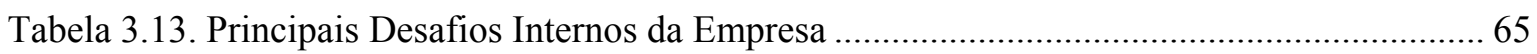

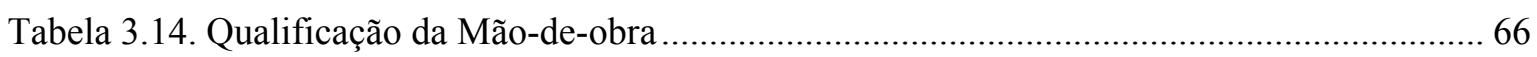

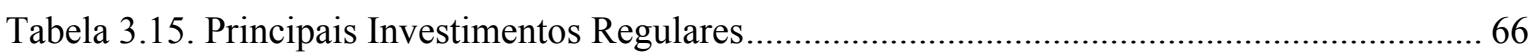

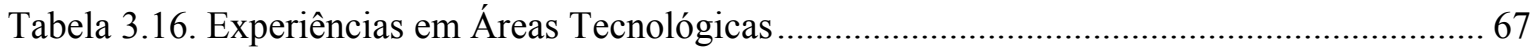

Tabela 3.17. Percentual Médio do Faturamento Investido em P\&D no Último Triênio................... 68

\section{Capítulo 4}

Tabela 4.1. Empresas da Saúde Participantes do Consórcio de Exportação ....................................... 70

Tabela 4.2. Serviços Oferecidos pelos Sindicatos de Fabricantes....................................................... 71

Tabela 4.3. Vantagens Locacionais de Ribeirão Preto .......................................................................... 73

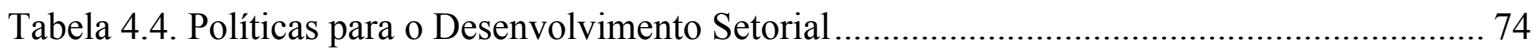

Tabela 4.5. Número de Vagas Oferecidas pelas Faculdades............................................................ 75

Tabela 4.6. Número de Laboratórios e Pesquisas ........................................................................... 76

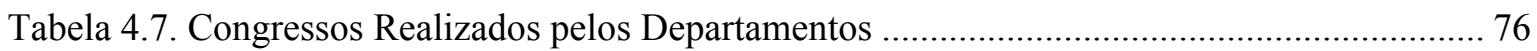




\section{Introdução}

O aumento da competição entre os países e entre as regiões do mundo tem suas conseqüências também para os municípios e para as regiões dentro de um mesmo país ou estado. $\mathrm{O}$ esforço para atrair investimentos aumenta à medida que o investidor passa a ter um leque muito maior de possibilidades de investimentos tanto no país como no exterior. O processo de abertura comercial, ao intensificar brutalmente a concorrência entre as empresas, apresenta um desafio às cidades porque são nestas que ocorrem as atividades de produção e consumo, entre outras decisões econômicas. Neste processo, a localidade passa a ter maior destaque na função que pode desempenhar para o desenvolvimento econômico do país ${ }^{1}$. A justificativa deste trabalho está no reconhecimento da importância das iniciativas locais para o desenvolvimento das cidades e da economia como um todo.

Soma-se à necessidade de resposta das cidades, a reorganização do Estado que, na última década, passou por um vasto processo de descentralização, transferindo várias responsabilidades aos estados e municípios, o que reforça a importância das forças locais como agente estratégico para o desenvolvimento econômico. Mas ao falarmos da importância das cidades como unidade de desenvolvimento econômico de um país, devemos considerar conseqüentemente as formas dos diferentes sistemas produtivos locais na geração de riquezas na sociedade.

O objetivo principal deste estudo é analisar a indústria de equipamentos médicos, hospitalares e odontológicos em Ribeirão Preto usando a literatura dos clusters como referencial teórico. Com isto, espera-se poder delinear as possibilidades do desenvolvimento de um cluster na área de equipamentos médicos, hospitalares e odontológicos entre as empresas do município como um meio de alavancar o crescimento das empresas e dinamizar a economia local, aproveitando-se da produção local e do aparato institucional existentes.

Entre os vários tipos de sistemas locais de produção, os clusters são uma forma de concentração geográfica e setorial geralmente de pequenas e médias empresas que mantêm um relacionamento sistemático possibilitando que estas firmas sejam mais competitivas (Igliori, 2001). As vantagens dos clusters a priori podem vir apenas da concentração

\footnotetext{
${ }^{1}$ A localidade como fonte geradora de riqueza, vista como tal, é um enfoque que vem sendo cada vez mais explorado. Veja J. Alden (1996): Urban Development Strategies: The Challenge of Global to Local Change for Strategic Responses.
} 
geográfica e setorial em si, como por exemplo, as vantagens decorrentes da instalação de empresas de fornecedores na região do cluster, da provisão de bens coletivos, da especialização da mão-de-obra local, do conhecimento tácito que se cria em torno do setor e dos ganhos de informação sobre o que cada firma está produzindo. Este tipo de benefício da aglomeração são as denominadas economias externas de Marshall ${ }^{2}$. Por outro lado, as vantagens da proximidade das firmas podem resultar de uma postura ativa das empresas em se organizarem, criando poder nas negociações junto aos fornecedores, abrindo espaço para investimentos conjuntos em pesquisa, desenvolvendo estratégias de acesso ao mercado externo e aproximando-se da universidade, dos órgãos públicos etc ${ }^{3}$.

Muitas são as vantagens potenciais deste tipo de arranjo, principalmente no que se refere a este último aspecto da ação associativa deliberada das empresas, mas o sucesso de um cluster dependerá em grande parte da cultura empresarial existente e da capacidade dos empresários em trabalharem em conjunto.

Os clusters podem ser tanto de empresas que fabricam produtos tradicionais de baixo nível tecnológico como de empresas de base tecnológica (EBTs). Empresas de base tecnológica, segundo Fernandes et alii (2000), são empresas que estão envolvidas de forma sistemática no desenvolvimento de novos produtos e novos processos de produção, de tal forma que o seu desenvolvimento tecnológico e, em parte, os investimentos em P\&D sejam uma característica intrínseca do negócio. Uma característica marcante deste tipo de empresa é que a inovação, através do uso de conhecimento técnico e científico, é fundamental para a sua permanência no mercado. Fernandes et alii (2000) também enfatiza a importância de se distinguir as empresas de base tecnológica das empresas modernizadas, que buscam a incorporação do conhecimento tecnológico ou de novos produtos como um meio de diminuir custos ou aumentar suas vendas, mas nas quais a inovação não necessariamente seja fundamental. No caso das empresas de base tecnológica, a inovação é o próprio produto da empresa.

As empresas de base tecnológica podem fazer parte dos sistemas de inovação. Os sistemas de inovação, apesar de não terem necessariamente uma delimitação geográfica precisa, podem se constituir em um tipo de cluster se puderem ser caracterizados como sistemas regionais de inovação. Os sistemas de inovação podem ser vistos como redes de relações

\footnotetext{
2 Alfred Marshall em "Princípios de Economia" (1920).

${ }^{3}$ Sobre aglomerações e competitividade das empresas ver Cassiolato e Lastres, Revista Brasileira de Competitividade, abr.-jul. 2001.
} 
institucionais, formais e informais, que dão sustentação ao desenvolvimento tecnológico e, como foi dito acima, podem ser de caráter nacional, regional ou até mesmo supranacional. Como nos clusters, são de fundamental importância para estes sistemas as relações sociais e a qualidade da cooperação existente entre seus integrantes. Os sistemas de inovação também podem surgir pela interação entre as firmas, a universidade e os órgãos públicos, sendo de grande utilidade o papel que o governo pode desempenhar como promotor da unidade entre seus membros. A estrutura institucional pode ter uma função importante na promoção do desenvolvimento tecnológico.

O setor de equipamentos médicos, hospitalares e odontológicos engloba uma gama muito variada de produtos, com diferentes densidades tecnológicas. Convivem neste mercado as grandes multinacionais com uma produção diversificada e altamente sofisticada e as pequenas e médias empresas especializadas em alguns produtos muitas vezes mais simplificados. As empresas multinacionais dominam o setor nos equipamentos de alta tecnologia, estas empresas possuem uma grande vantagem em relação às nacionais menores devido à sua estrutura de comercialização que articula a venda dos produtos, e principalmente dos pacotes de produtos, ao fornecimento de assistência técnica e ao financiamento.

O crescimento da produção nacional, portanto, esbarra não apenas no diferencial tecnológico entre as empresas nacionais e estrangeiras, mas também neste poderoso mecanismo de comercialização que acaba atraindo para si os maiores compradores, como as licitações públicas, através dos pacotes fechados ${ }^{4}$.

Nesta direção, Furtado (s/d) propõe que os países em desenvolvimento adotem políticas de saúde mais adequadas aos seus recursos e às necessidades de sua população, priorizando a universalização dos serviços de saúde. Neste caso, a aquisição de produtos simplificados pode ser uma estratégia que vai ao encontro da universalização dos serviços, uma vez que os recursos são limitados. No entanto, o autor ressalta que ao falar em produtos simplificados não se refere necessariamente a produtos menos avançados tecnologicamente, ou produtos que sejam de baixa qualidade.

A priori, parece-nos que este tipo de estratégia produtiva é adotado por algumas empresas do município de Ribeirão Preto, o que deverá ser verificado durante a pesquisa de campo

\footnotetext{
${ }^{4}$ Outro aspecto das licitações públicas levantado por Melo (Revista do BNDES, 2000) em estudo sobre a indústria de equipamentos de hemodiálise no Brasil é a necessidade de planejamento das compras do governo para que não se penalize a indústria nacional por falta de capacidade produtiva em responder imediatamente à demanda pública.
} 
com as empresas. Apesar de não ser o objetivo primeiro deste estudo, as potencialidades desta indústria na direção dos produtos simplificados poderia apontar uma alternativa à importação dos equipamentos médicos, setor responsável por elevados déficits na balança comercial brasileira. Além disso, a substituição de importações permitiria a redução dos custos de assistência técnica, um dos principais itens de custos dos hospitais.

Voltando nossa atenção para o município, Ribeirão Preto é conhecida por ser um centro de excelência no ensino superior na área da saúde e na prestação de serviços da saúde. A concentração de um grande número de profissionais da saúde e a presença da universidade criou um ambiente favorável para a instalação de várias empresas deste setor no município. Além da Universidade de São Paulo, a instalação de uma empresa de maior porte no setor odontológico na década de 40, também foi um fator historicamente importante para o surgimento posterior de outras empresas do mesmo setor.

O setor da saúde em Ribeirão Preto gerou em 1998 um total de 11045 empregos formais entre empregos da indústria, comércio e serviços (RAIS, 1999). A indústria da saúde na cidade se divide na fabricação de produtos farmacoquímicos, medicamentos, materiais, instrumentos óticos, equipamentos e instrumentos para uso médico, hospitalar e odontológico entre outros.

O diagnóstico da indústria de equipamentos médicos, hospitalares e odontológicos em Ribeirão Preto e a caracterização das relações existentes entre os agentes do arranjo produtivo, podem servir de base para o desenvolvimento de um cluster da saúde na região de Ribeirão Preto. O desenvolvimento do cluster teria como primeiro passo a articulação das forças produtivas já existentes, aproximando as empresas da universidade, com seus núcleos de pesquisas e dos órgãos públicos, de modo que as tecnologias desenvolvidas pelos grupos de pesquisadores nas universidades possam ser melhor aproveitadas comercialmente. A articulação organizada das empresas poderia trazer ganhos maiores para todos, criando capacidade de exportação e de investimento em novas pesquisas, gerando empregos etc. $\mathrm{O}$ governo local poderia fazer a ponte inicial entre as empresas e a universidade e até mesmo buscando formas de financiamento.

No capítulo 1 devemos estudar e comparar o funcionamento dos clusters e dos sistemas locais de inovação, priorizando os pontos em comum destes dois tipos de arranjos. Estudaremos como os clusters e os sistemas locais de inovação podem ser usados para promover o desenvolvimento regional e as forças que estariam atuando para o desenvolvimento de um cluster como os custos de transporte, o ambiente institucional, o 
número de empresas já em funcionamento e as características das empresas que poderiam favorecer a formação de um cluster entre outros fatores.

O capítulo 2 analisa a indústria de equipamentos médicos, hospitalares e odontológicos no Brasil e no mundo. Buscamos caracterizar o setor quanto ao padrão de concorrência, ao tamanho das empresas, ao grau de desenvolvimento tecnológico, à evolução da produção nacional, ao tipo de produto oferecido, às estratégias adotadas pelas empresas etc.

O capítulo 3 enfoca as empresas locais do setor médico, hospitalar e odontológico. Esta parte do trabalho compreende pesquisa de campo com as empresas do setor estabelecidas no município. Neste capítulo há uma vasta caracterização das empresas locais quanto ao porte das empresas, à capacidade de exportação, às formas de comercialização, às inovações tecnológicas, ao grau de concorrência, à localização dos principais fornecedores, à caracterização do mercado consumidor entre outros fatores.

O capítulo 4 faz um levantamento e busca desenhar o perfil do arranjo produtivo local em suas características que o aproxima ou o distancia de um cluster industrial. Para isto, foi realizada pesquisa de campo com as empresas e com os laboratórios de pesquisa das faculdades. O capítulo encerra com o levantamento das possibilidades de desenvolvimento do cluster de equipamentos médicos, hospitalares e odontológicos no município. 


\section{Capítulo 1}

\section{Concentração Geográfica das Firmas, Clusters e Sistemas de Inovação.}

$\mathrm{Na}$ história do pensamento econômico, muitas vezes foi dada maior ênfase nos fatores históricos e temporais nas explicações econômicas que nos aspectos ligados à geografia. Entretanto, nas últimas décadas vem se observando um movimento de maior atenção aos estudos de economia espacial e desenvolvimento regional nas teorias econômicas (Haddad, 1989).

Atualmente, em vários países do mundo, a atenção ao desenvolvimento regional passou a ser vista como questão fundamental para o fortalecimento da economia do país, principalmente à medida que a ampliação do sistema produtivo nacional vem tornando-se limitada pela alta concentração geográfica da população causada por um intenso processo de metropolização.

Os economistas clássicos consideravam apenas alguns fatores não econômicos, como os recursos naturais, na explicação da localização espacial das firmas. O descaso com a distribuição das atividades econômicas no espaço geográfico advinha, em parte, pela suposição de equalização dos preços dos fatores, de um mercado de concorrência perfeita, com perfeita mobilidade dos fatores, e da suposição de custos nulos de transporte. Por estas considerações, as desigualdades dos níveis de produção entre as regiões eram eliminadas automaticamente (Haddad, 1989).

Em linhas gerais, as teorias da localização da atividade econômica delineavam-se principalmente pela maximização do lucro através da minimização dos custos de transporte, matéria-prima e produto. No século XIX, surgiram as primeiras tentativas de identificar os fatores locacionais que poderiam significar as vantagens e desvantagens de uma região específica em receber atividades industriais, agropecuárias etc. Naquela época, alguns autores já apontavam para as forças de aglomeração e desaglomeração na explicação espacial da atividade econômica. No entanto, estas questões ainda eram muito pouco exploradas, como um esboço do que seria caracterizado por Marshall de economias externas no início do século seguinte.

Na segunda metade do século XIX, os economistas da Escola Austríaca Alemã passaram a considerar a economia como um fenômeno social que não poderia ser desvinculado do sistema político-social-institucional existente e somente poderia ser entendida e analisada se fosse pesquisada como parte de uma ordem social, que sofresse influência dos costumes, 
da lei, da educação, da política e da religião. Segundo os autores desta escola, a economia sofreria mutações à medida que os fenômenos com os quais ela se inter-relacionasse intimamente também evoluíssem historicamente. Esta abordagem sócio-institucional levantada por estes autores aparecerá mais tarde no estudo dos distritos industriais.

Os estudos de economia regional enfatizavam a importância da localização da indústria na redução dos custos. Utilizava-se de modelos geométricos, análogos aos de equilíbrio de forças da física, como os triângulos locacionais, para se determinar o ponto de custo mínimo ${ }^{5}$. Nos triângulos locacionais, cada vértice eram forças de atração e o ponto de equilíbrio estaria em um ponto qualquer dentro do triângulo. Este ponto representava um custo de transporte mínimo.

Segundo Hoover apud Haddad (1989), tem-se a distinção de três novos fatores importantes para o estudo da economia regional: 1) as economias de escala dentro da firma, devido ao aumento de produção, 2) as economias de localização dentro da indústria e 3) as economias de urbanização, devido à existência de firmas de indústrias diferentes em um mesmo local. Estas distinções se assemelham a alguns aspectos das teorias das aglomerações.

Durante a década de 70, com o desempenho dos distritos industriais italianos, os estudos sobre economia regional ganharam novos enfoques sobre a importância da localização industrial $^{6}$. Ganha força a percepção de que o fato de várias firmas estarem situadas em uma mesma localidade pode ser uma fonte de vantagens em $\mathrm{si}^{7}$. Nesta época, tem-se início os primeiros estudos sobre o que podemos chamar de economia das aglomerações. Posteriormente, novos conceitos como o papel das instituições e das vantagens estratégicas desenvolvidas pelas firmas irão enriquecer o conhecimento sobre a localização industrial.

\footnotetext{
${ }^{5} \mathrm{O}$ fator locacional de Alfred Weber (1929) era um ganho que a empresa tinha por se localizar em uma determinada região. Weber distinguia os fatores naturais, técnicos, sociais e culturais. O autor determinava o ponto de custo mínimo de transporte por meio de um triângulo locacional.

${ }^{6}$ Estes estudos da década de 70 tiveram uma contribuição importante do conceito de economias externas desenvolvido por Marshall no início do século XX.

${ }^{7}$ Sobre a Terceira Itália ver Best, M. (1990). The New Competition.
} 


\subsection{O que são os clusters?}

Os sistemas produtivos locais têm um importante papel no crescimento econômico e no desenvolvimento de um país. Entre os vários tipos de sistemas locais de produção, os clusters são uma forma de concentração geográfica e setorial geralmente de pequenas e médias empresas que mantêm um relacionamento sistemático entre si, e que possibilita que estas firmas sejam mais competitivas. Os clusters podem ser tanto de empresas que fabricam produtos tradicionais de baixo nível tecnológico como de empresas de base tecnológica.

Alguns autores consideram a definição de cluster como a que foi dada acima, que será utilizada neste trabalho. Outros, utilizando-se de uma concepção mais ampla, consideram cluster apenas a aglomeração geográfica e setorial das firmas sem que ocorram especialização e cooperação por definição (Altenburg \& Meyer-Stamer, 1999).

O mais importante para a caracterização do que chamaremos de cluster será a relação entre as firmas, e a relação entre elas e o governo, a universidade e outras instituições relacionadas. São estas possibilidades de estratégias conjuntas que podem aumentar consideravelmente a produtividade das empresas dentro de um cluster, por gerar o que chamamos de eficiência coletiva. O conceito de eficiência coletiva, desenvolvido primeiramente por Schmitz (1997), é muito esclarecedor para podermos distinguir os diversos tipos de arranjos: a eficiência coletiva é a vantagem competitiva que vem da soma das externalidades e da ação conjunta. Se as externalidades (ou economias externas) surgem como um subproduto não intencional da concentração, a ação conjunta é a organização intencional entre as firmas, tanto entre as firmas individuais, como de grupos de empresas organizadas em associações, consórcios produtivos etc. A ação conjunta pode promover um grande diferencial de competitividade entre as firmas dos clusters e as firmas que estão fora do cluster.

Segundo Schmitz (1997), em estudo sobre clusters nos países em desenvolvimento, estes arranjos têm ajudado as firmas de pequeno porte destes países a superarem as restrições para o seu crescimento, conseguindo atingir mercados mais distantes e inclusive, têm contribuído para que estas firmas consigam exportar seus produtos. $\mathrm{O}$ autor salienta que o crescimento e a competitividade de várias empresas nestes países não poderiam ser corretamente compreendidos analisando-se as firmas isoladamente. 
Entretanto, Schmitz (1997) aponta para a grande disparidade que há entre o desempenho dos clusters nos países em desenvolvimento, citando o caso dos países da África, onde este tipo de arranjo vem tendo pouco impacto para o sucesso das empresas e, de outro lado, os clusters na América Latina e em alguns países da Ásia cujas empresas vêm mostrando um grande crescimento e aumento da competitividade no mercado internacional. Estas diferenças entre os clusters dos vários países poderiam em parte ser explicadas pela capacidade das firmas em se organizarem, reforçando a importância do conceito da eficiência coletiva.

Além dos clusters, outro tipo interessante de arranjo são as redes de firmas que cooperam entre si no aprendizado mútuo e na inovação coletiva sem que haja concentração geográfica. Neste caso, a eficiência coletiva ocorre principalmente pela ação conjunta, com externalidades muito fracas, ou até mesmo nulas, por não haver concentração (Garcez, 2000).

Apesar da vulnerabilidade que pode representar para a economia regional, por concentrar a produção em alguns produtos, são muitas as vantagens potenciais dos clusters, motivo que os torna tão atrativos como objeto de política pública, tornando-os alvo de atenção de governos de vários países e de organizações mundiais, principalmente a partir destas últimas três décadas.

Entretanto, reforçando o que foi dito anteriormente, deve-se sempre levar em consideração que o sucesso dos clusters depende em grande parte da cultura empresarial local e da capacidade dos empresários em trabalharem em conjunto. Quanto a este aspecto, que veremos com mais detalhes nos próximos capítulos, Altenburg e Meyer-Stamer (1999) destacam que os fatores qualitativos podem aumentar consideravelmente o desempenho dos clusters e que a falta de espírito empreendedor, de parcerias e a falta de confiança são geralmente os maiores empecilhos para o desenvolvimento dos clusters.

Ao contrário do que muitas vezes encontramos na literatura, nem sempre os clusters surgiram do espírito empreendedor dos empresários, como no caso famoso da Terceira Itália. Krugman (1991) aponta para o fato de que três importantes pólos tecnológicos dos EUA surgiram a partir de iniciativas externas ao meio empresarial. É o caso do Vale do Silício que começou com incubadoras por iniciativa da Universidade de Standford e muitas firmas começaram a surgir a partir do centro de pesquisa criado dentro desta universidade, é também o caso da Route 128 que nasceu pela iniciativa de um presidente do MIT que começou a encorajar os que estavam dentro da universidade, professores e pesquisadores, a 
tornarem-se empresários e ajudando na captação de capitais de risco para tais investimentos, e do Research Triangle na Carolina do Norte que teve início a partir de um suporte estatal para a criação de um centro de pesquisas.

Os clusters podem ser analisados sob vários aspectos do ponto de vista teórico e empírico. Em Suzigan (1999) encontramos uma interessante distinção das principais abordagens da literatura de cluster, e seus principais representantes, que utilizaremos a seguir:

A nova geografia econômica, Krugman apud Suzigan (1999), em que uma aglomeração industrial pode surgir a partir de um acidente histórico e da presença de economias externas acidentais e incidentais. Segundo esta linha de estudo, há pouco espaço para políticas públicas. Estas poderiam resolver problemas de falha de mercado que surgissem ao longo do funcionamento do cluster.

A economia dos negócios, Porter apud Suzigan (1999), que enfatiza a importância da concentração das habilidades locais para as inovações comerciais e tecnológicas, possibilitando um salto de competitividade das firmas. Como são as forças de mercado que geram a competitividade do cluster, o governo fica apenas como provedor de educação, infra-estrutura e agente legislador.

A abordagem da economia regional, Scott apud Suzigan (1999), segundo a qual há uma tendência do capitalismo a se organizar em clusters e em que as políticas públicas podem criar fortes vantagens competitivas regionais.

A economia da inovação, Audretsch apud Suzigan (1999), que enfatiza que a concentração geográfica das firmas aumenta suas capacidades de avanço tecnológico por criar um ambiente propício para a geração de conhecimento por existir várias pessoas interessadas sobre um setor em um mesmo local e pelo desenvolvimento de um conhecimento tácito sobre este setor. Além disso, observam que as empresas baseadas em conhecimento inovador tendem a se concentrar em um mesmo espaço.

A abordagem das pequenas empresas e distritos industriais, Schmitz apud Suzigan (1999), que enfatiza a ação conjunta e consciente das firmas na criação de vantagens competitivas regionais, em parceria e apoio do setor público.

Estas abordagens não são excludentes, ao contrário, pode-se encontrar vários destes aspectos se complementando em um cluster em funcionamento (Suzigan, 1999). Na nossa análise há elementos de várias destas abordagens: este trabalho pode se inserir na caracterização de cluster na linha das pequenas empresas e distritos industriais e como um 
agente dinamizador da economia regional. Além disso, podemos dizer que alguns aspectos deste trabalho se aproximam da abordagem da nova geografia econômica, quanto à explicação do surgimento dos clusters, e da economia da inovação, se considerarmos o cluster como estratégia para alavancar o potencial inovador das firmas pertencentes ao cluster.

\subsection{De onde vem as vantagens da concentração geográfica das firmas?}

A partir da década de 80 passou-se a dar maior ênfase ao comportamento dos mercados de competição imperfeita e ao papel exercido pelos retornos crescentes na organização da produção. As vantagens da especialização e da concentração geográfica das firmas, que traziam consigo os retornos crescentes, independentemente das vantagens comparativas, passaram a ser usadas também na explicação do comércio (Krugman 1991).

Marshall no seu livro Princípios de Economia (1920) identifica que o ganho de competitividade obtido pela concentração geográfica das firmas está na possibilidade de obtenção de economias externas. Enquanto as economias internas estariam relacionadas à escala de produção da firma, as economias externas seriam a consequência do crescimento do setor industrial como um todo, não sendo obrigatoriamente relacionadas ao tamanho da firma.

Este autor identificou três fontes de economias externas advindas da concentração geográfica das firmas, que são:

a) A concentração das empresas num mesmo local possibilita uma maior concentração de mão-de-obra especializada, o que beneficia tanto os empresários como os trabalhadores que migram para esta região, atraídos pela quantidade de firmas. A concentração possibilita a queda do custo de transação relacionado ao custo de procura tanto para as firmas como para os trabalhadores.

Considerando que as demandas das firmas por trabalhadores não são perfeitamente correlatas, caso um trabalhador seja demitido, ele terá maior facilidade em arrumar outro emprego onde houver alguma concentração das firmas. Pelo lado da firma, caso ela esteja em um período de expansão da produção, terá mais facilidade em contratar se houver concentração de mão-de-obra. Krugman (1991) enfatiza que não é apenas o fator incerteza que leva à concentração, porque se assim fosse, bastaria que as firmas dividissem sua produção entre duas regiões para que se tivesse o mesmo efeito da concentração. A 
consideração conjunta do fator incerteza e dos retornos crescentes é que nos dá o argumento da concentração de mão-de-obra.

Krugman (1991) ressalta que o argumento do mercado de mão-de-obra não é dependente das hipóteses de salários fixos ou de falhas no mercado de trabalho. Caso os salários sejam flexíveis, se houver concentração, haverá uma menor flutuação dos salários, beneficiando tanto os trabalhadores como os produtores. Caso uma firma esteja em expansão (por exemplo, porque criou um novo produto), este produtor conseguirá empregar mais do que se estivesse isolado, e não terá o peso de salários que sobem muito. Por outro lado, no caso de uma piora nas condições de uma firma isolada, a queda salarial que poderia ocorrer se houvesse uma só firma no mercado poderá ser compensada pela demanda de outras que não estejam passando pelas mesmas dificuldades.

b) O desenvolvimento de um mercado fornecedor, devido a uma maior demanda para estas firmas de insumos e serviços especializados, possibilitando a oferta de maiores quantidades e variedades a menores custos. Um mercado grande pode tornar viável, por exemplo, que estas empresas invistam em novas máquinas e processos produtivos ou no uso de equipamentos mais caros.

A justificativa para o desenvolvimento de uma indústria de insumos também dependerá da existência de economias de escala, porque, caso contrário, uma firma poderá se replicar criando duas firmas de tamanho pequeno, acabando com o argumento da concentração. Apenas a consideração dos retornos crescentes pode tornar a concentração em um centro mais eficiente e atrativo que a produção em dois centros menores.

c) A criação de condições para o desenvolvimento tecnológico também pode ser um dos resultados benéficos da concentração geográfica e setorial das firmas devido ao fato das informações e das invenções fluírem mais facilmente e em uma velocidade maior que em grandes distâncias, proporcionando saltos tecnológicos. A concentração das firmas possibilita o desenvolvimento de um conhecimento tácito sobre um determinado setor.

Mas além das vantagens das economias externas apontadas inicialmente por Marshall, outros autores como Schmitz, Nadvi e o próprio Krugman passaram a considerar uma outra natureza de vantagens, com uma capacidade de exploração muito maior, que são fruto da capacidade das empresas em se organizarem como grupo. Os clusters podem colocar as firmas numa condição competitiva mais elevada justamente pela possibilidade de se obter ganhos de eficiência que se tem pelo agir em grupo, conseguindo um maior poder de 
barganha junto aos fornecedores, com maiores possibilidades de investimentos conjuntos em pesquisa, de estabelecimento de estratégias de acesso ao mercado externo, de manterem relacionamentos frutíferos com a universidade e órgãos públicos etc. É o conceito de eficiência coletiva (Schmitz, 1997) desenvolvido na seção anterior por necessidade de se estabelecer o que se caracteriza como cluster.

\subsection{O que determina a existência de um cluster numa região específica?}

A economia regional e a geografia econômica estudam a localização da produção entre as regiões de um país. Com a globalização e a formação dos blocos econômicos, estes estudos também podem ser aproveitados na explicação das relações comerciais entre os países. Além disso, a difusão de conceitos como retornos crescentes, competição imperfeita e o papel histórico no desenvolvimento econômico, abriu maior espaço para estas áreas da economia (Krugman, 1991).

Mas por que as empresas de um determinado setor estão concentradas em uma determinada região do país ou do estado e não em outra qualquer?

A concentração geográfica das firmas pode ser explicada a partir de diferentes fatores de acordo com o tipo característico da indústria que se está considerando. Entre estes fatores estão a proximidade do mercado consumidor, a facilidade de acesso à matéria-prima, o desenvolvimento do sistema de transportes e, em alguns tipos de indústria, a existência do aparato científico das universidades entre outros.

Um exemplo de como estariam atuando estes fatores, o desenvolvimento dos meios de comunicação e dos meios de transporte podem estar agindo a favor da concentração. Pensemos no caso em que o custo transporte comece a ficar relativamente mais barato que os custos fixos de se montar uma nova filial da empresa próxima a outro centro consumidor. Assim, será mais atrativo para o empresário atender vários mercados a partir de um mesmo local onde passa a produzir em maior quantidade. Portanto, é importante notarmos que a transformação das condições de oferta e do nível de desenvolvimento dos fatores pode alterar o mapa da localização das empresas.

Além destas condições de oferta, Krugman (1991) fala dos "acidentes históricos" que deram origem a muitos distritos industriais nos EUA e em outras partes do mundo. Segundo este autor, a captura de vantagens transitórias poderia explicar a localização de 
uma indústria numa certa região e, conseqüentemente, as diferenças de desenvolvimento entre as regiões.

A "captura" das vantagens transitórias poderia ocorrer da seguinte forma: a partir de um fato histórico qualquer, se uma concentração geográfica inicial das firmas proporcionar retornos crescentes, e se houver condições favoráveis de demanda e dos custos de transporte, tem-se o início de um determinado processo cumulativo em que quanto maior o número de firmas e trabalhadores na região, maior a atração de novas firmas e trabalhadores para este local. Assim, os retornos crescentes e os processos cumulativos teriam um papel decisivo no desfecho destes acidentes históricos.

Conforme Krugman (1991), um aumento da produção agrícola e, portanto, da riqueza, poderia dar início a um movimento de acumulação, seguido de um processo de substituição de importações e de crescimento, atraindo mão-de-obra para a região e dando início a um processo circular de crescimento. Este autor aponta para o fato de que a Califórnia no século XIX era um mercado local muito pequeno e sem indústria onde a população cresceu com a descoberta de petróleo, na passagem do século, começando um crescimento gigantesco, que fez com que Los Angeles se tornasse um grande centro industrial.

O raciocínio seria o de que, uma vez que uma certa concentração passasse a existir, as vantagens que as firmas poderiam adquirir por estarem perto uma das outras desestimularia os produtores a se mudarem. Seria o caso do que teria acontecido com o manufacturing belt, na região nordeste dos EUA, que emprega $70 \%$ do emprego industrial do país, mesmo situado em uma região em que não há vantagens em recursos naturais e onde a produção mineral e agrícola saiu de lá para outras regiões do país. Se o manufacturing belt usava inicialmente recursos minerais da região, a partir da metade do século XX passou a importar de outras regiões.

A versão de Krugman para o manufacturing belt nos EUA é que no passado a possibilidade de apenas pequenas economias de escala e os altos custos de transporte levava a uma baixa concentração geográfica da produção industrial, e a indústria nascia onde houvesse população agrícola. A partir da segunda metade do século XIX, as economias de escala cresceram e os custos de transporte baixaram, crescendo a parcela da população em ocupações não agrícolas. Estas vantagens iniciais foram capturadas pelo manufacturing belt. Os retornos crescentes para cada firma individual e as economias externas resultante da interação entre as firmas deram início a um processo de acumulação. 
Krugman desenvolve um modelo simplificado em que há duas possibilidades de localização da produção, leste e oeste. Os produtos agrícolas são produzidos usando-se apenas a terra como fator específico de localização e a população agrícola é dividida exogenamente em $50 \%$ no leste e $50 \%$ no oeste. Os produtos manufaturados podem ser produzidos em ambos os lugares: caso sejam produzidos em um só lugar tem-se um custo transporte enquanto se produzidos nos dois lugares incorre-se em um custo fixo por se ter duas plantas. A população ligada à indústria é proporcional à produção industrial enquanto a demanda por produtos manufaturados é proporcional à população.

Em seu exemplo numérico o autor propõe que ${ }^{8}: 60 \%$ da força de trabalho sejam fazendeiros (30\% no leste e $30 \%$ no oeste) e $40 \%$ seja da indústria. O total da demanda seja de 10 unidades de produto, o custo fixo de se criar uma nova planta seja 4 e o custo transporte seja de 1 por unidade transportada.

Caso toda a produção industrial esteja no leste, a população do leste será de $70 \%$ (30\% do setor agrícola e $40 \%$ da indústria). O consumo do leste será de 7 unidades (3 para o setor agrícola e 4 para a indústria). $\mathrm{O}$ oeste vai demandar apenas 3 unidades para a sua população de fazendeiros. Caso a produção industrial seja dividida ao meio, a população de cada região será de $30 \%$ de fazendeiros e $20 \%$ da indústria. Nesta situação, a demanda será de 5 unidades para cada região (3 para o setor agrícola e 2 para a indústria).

Como podemos observar, a estratégia de localização de uma firma dependerá da estratégia das outras firmas. Suponha que toda a indústria esteja concentrada no leste. Logo, uma firma terá uma demanda no leste de 7 e uma demanda no oeste de 3 . Se ela se estabelecer no leste terá um custo de 4 para implantar a firma e um custo 3 de custo transporte para vender seu produto no oeste. Portanto, terá um custo total de 7 . Se decidir se estabelecer no oeste seu custo total será de 11 (custo fixo de 4 mais custo transporte de 7) ao passo que se decidir por duas plantas terá um custo igual a 8 que corresponde ao custo de duas plantas sem que haja custo transporte. A conclusão que se tira deste exemplo simples é que se todos estiverem no leste é melhor para a firma individual também se estabelecer no leste.

Neste exemplo há três equilíbrios possíveis. Caso a produção seja dividida entre leste e oeste, com uma demanda de 5 unidades de produto para cada região, se uma firma específica concentrar sua produção apenas no leste ou oeste, o seu custo total será de 9

\footnotetext{
${ }^{8}$ Krugman, P. Geography and Trade 1991.
} 
(custo fixo de 4 e custo transporte igual a 5). Mas se ela divide sua produção entre as duas regiões, passa a ter um custo de 8 (custo fixo de duas plantas sem que haja custo transporte). Deste modo, se a indústria se dividir, é melhor que a firma individual também divida sua produção. À parte as economias de escala, se os custos fixos não forem tão grandes em relação ao custo transporte, e se houver demanda nas duas regiões, será provável que haja produção industrial nos dois lugares. Mas se os custos fixos forem grandes em relação ao custo transporte, a indústria se localizará onde houver o maior mercado e, portanto, o equilíbrio dependerá de onde se começa, ou seja, o fator histórico é importante. A indústria estará onde estiver o maior mercado, mas o maior mercado está onde está a indústria (Krugman, 1991).

No entanto, a predominância do fator histórico dependerá de outros fatores como: os custos fixos permanecerem elevados; a existência de economias de escala consideráveis; de uma produção que não dependa dos recursos naturais de uma região específica, de custos transporte baixos. Se Po for a parcela da população total que está no oeste, V o total de vendas da firma, F o custo fixo de se abrir uma planta e t o custo transporte por unidade, enquanto $\mathrm{PoVt}<\mathrm{F}$ compensará fabricar no leste para vender no oeste 9 .

O custo de transporte também tem um papel crucial na explicação da localização da indústria. Este pode ser visto como um fator endógeno, ou seja, ao mesmo tempo em que as vantagens da concentração industrial vieram da existência de rodovias que ligavam as cidades de uma região, a presença destas rodovias, em parte, foi devido à existência das indústrias locais. A possibilidade de economias de escala nos custos de transporte (como aviões grandes e mais eficientes, que só são viáveis para demandas maiores) reforça as vantagens e a concentração industrial de uma região. Estas economias de escala podem surgir pelo aumento do volume de transporte entre as regiões, o que é possível pela concentração geográfica das firmas.

O desenvolvimento e a diminuição dos custos de transporte fazem uma grande diferença. A possibilidade de duas regiões serem vistas pelo produtor como um só mercado cria vantagens para estas regiões, podendo torná-las mais atrativas que as outras, mesmo que seus mercados individuais não sejam grandes. Se a população representa o potencial do mercado local, são as condições de transporte que dão as possibilidades de acesso aos outros mercados.

\footnotetext{
${ }^{9} \mathrm{Se}(1-\mathrm{Po}) \mathrm{Vt}<\mathrm{F}$ será melhor concentrar a produção no oeste. Caso sejam falsas ambas as proposições o equilíbrio será a produção nas duas regiões.
} 
Enfim, a concentração geográfica da indústria poderia ser explicada pela interação entre retornos crescentes, custos de transporte e existência de demanda, além de um componente histórico arbitrário. Além disso, em alguns casos também foi importante a iniciativa de agentes externos ao setor produtivo como a universidade e o setor público.

\subsection{Os clusters e os sistemas de inovação.}

\subsubsection{Algumas considerações sobre o processo inovativo.}

Segundo Cassiolato \& Lastres (1998), hoje há a percepção de que o processo inovativo é formado por inúmeras ligações ao longo da cadeia produtiva, e até mesmo entre concorrentes. Tanto nos EUA como na Europa, as políticas de inovação são pensadas a partir deste conhecimento, considerando o processo produtivo como algo colaborativo, de fases interligadas, com grande interação entre os agentes.

Dentro da firma, o processo de inovação passa a ser entendido sob uma ótica que vai além do investimento unicamente em P\&D, que pode ser extremamente conservador se usado apenas para cópia de produtos. No interior da fábrica o processo inovativo pode ser realizado através de intensa comunicação entre suas diversas instâncias, ou seja, os novos produtos e processos surgem pela interação entre as fases do processo produtivo ${ }^{10}$.

Na busca de quantificar as diferenças entre P\&D e o processo de inovação de maneira geral, alguns trabalhos chegaram ao resultado de que, mesmo para as grandes empresas, apenas $30 \%$ dos gastos com novos produtos e processos são estritamente P\&D. Sendo que, $30 \%$ dos gastos correspondem a outras atividades, internas à firma, ligadas ao processo inovativo, como design, marketing e engenharia, e $40 \%$ dos gastos estão relacionados ao investimento como um todo, como a compra de máquinas e equipamentos (Cassiolato \& Lastres, 1998).

Segundo este autor, estudos da OCDE mostraram que mesmo as pequenas empresas possuem gastos significativos na busca de inovação, e que estas empresas são mais inovativas do que se acreditava a dez anos atrás. Esta nova percepção da realidade só foi possível pela mudança no conceito do que é o processo inovativo.

\footnotetext{
${ }^{10}$ Cassiolato, J.E. em Seminários: Perspectivas do Desenvolvimento Econômico da Região de Ribeirão Preto. Julho, 2001.
} 
O desenvolvimento tecnológico ocorreria pela interação e troca de informações entre as firmas, os consumidores, os órgãos de pesquisa públicos e privados, as universidades e os órgãos públicos, considerando as características históricas, culturais e econômicas na organização das firmas e dos mercados (Cassiolato \& Lastres, 1998).

Os estudos sobre o processo inovativo constataram que este, de fato, não ocorre apenas através dos métodos formais de $\mathrm{P} \& \mathrm{D}$, mas através das atividades de produção, do consumo e principalmente pela interação entre vários agentes. É o que se chama de learning by doing, learning by using e learning by interacting (Garcez, 2000).

Para Lundvall (1988), a maioria das inovações de uma empresa se destina a uma outra firma, em uma relação fornecedor-cliente, por isso estas firmas devem ter incentivos de manterem relações maiores que apenas as do mercado para a produção de inovações. Esta necessidade das firmas ocorre porque o sistema de preços não consegue responder a questões qualitativas sobre os produtos e processos, não resolvendo muitos problemas de assimetria de informação e incerteza.

Deste modo, a atividade de inovação aconteceria melhor em estruturas mistas de mercado, tanto via preços, como pela troca de informações qualitativas e mesmo pela colaboração sistemática entre os agentes. Mas para que estas relações de cooperação possam ocorrer na atividade inovadora é necessário o desenvolvimento de confiança e regras, formais e implícitas, para a diminuição das incertezas. Lundvall argumenta que quanto maior a incerteza e a complexidade do produto, maior a necessidade de interação e colaboração. Com o aumento da frequência destas relações de cooperação, estas redes se tornariam mais eficientes na transmissão de conhecimento tácito e os parceiros só teriam incentivo em desmancharem a parceria se os custos tornarem-se não compensatórios, ou quando da possibilidade de parcerias mais lucrativas.

Enquanto Lundvall destaca as interações verticais entre usuários e produtores, outros autores como DeBresson apud Silva (2000) focalizam as relações horizontais de colaboração, tanto entre concorrentes como com os órgãos de pesquisa. Para DeBresson a inovação consiste em uma recombinação de recursos destinados a um novo uso. Há uma limitação para as firmas inovarem a partir de seus próprios recursos porque o custo de internalização e monitoramento de uma ampla gama de competências dentro da firma aumenta com a diversidade de competências que a firma queira incorporar. Por isso, o autor defende a idéia de que a firma deve combinar a exploração dos recursos internos com a busca de novos recursos fora da firma através de parcerias. Além de diminuir os riscos, 
as relações de parceria trariam externalidades positivas, ou seja, o total dos benefícios seria maior que a soma das partes.

Segundo Quadros et alii apud Silva (2000), as firmas brasileiras tenderiam a inovar a partir dos estímulos do mercado, ou seja, através das relações comerciais com os clientes, fornecedores e concorrentes, o que estaria de acordo com os dois autores citados acima.

Pesquisas realizadas para oito países da OCDE chegaram às seguintes conclusões sobre as atividades inovadoras da firma ${ }^{11}$ :

a) para uma firma inovar ela requer uma variedade de fontes externas de conhecimento, prevalecendo a composição de redes na atividade inovadora.

b) a forma mais comum de redes é a complexa, envolvendo uma grande variedade de agentes, como clientes, consumidores, fornecedores, concorrentes, etc.

c) na composição das redes de colaboração as firmas não contam apenas com outras organizações nacionais, havendo a presença de redes internacionais (Silva 2000).

Portanto, para todos estes autores comentados acima, a cooperação entre as firmas pode desempenhar um papel fundamental no processo de inovação, aumentando suas capacidades competitivas, principalmente quando se trata de pequenas competindo com grandes firmas, criando maior capacidade de investimento e maior difusão do conhecimento, o que aumenta as chances de acerto.

Para Cassiolato (1998) os benefícios da cooperação é um assunto que encontra poucas divergências na literatura atual, com muitos casos concretos de sucesso. Para mercados altamente competitivos, em que a inovação seja fundamental para a permanência da firma no mercado, a cooperação pode ser a melhor estratégia da firma.

Anteriormente, as políticas tecnológicas tradicionais eram pensadas a partir do raciocínio de que o processo inovativo ocorria através de fases sequenciais, em que se começava por pesquisa básica, passando por pesquisa aplicada, desenvolvimento experimental, produção e, finalmente, marketing, não havendo nenhuma ligação entre as fases. Tinha-se a noção de que havendo $\mathrm{P} \& \mathrm{D}$, haveria inovação. Em conseqüência desta noção sobre o processo inovativo, a visão que se tinha de política tecnológica baseava-se na idéia de que era preciso fortalecer as atividades de P\&D nas empresas.

\footnotetext{
${ }^{11}$ Estas pesquisas fazem parte da Community Innovation Survey I organizada pelo grupo de trabalho sobre sistemas nacionais de inovação da OCDE.
} 
Hoje se configura um novo formato de política na direção de se estimular processos cooperativos entre empresas e instituições de pesquisa. Entre as perspectivas de ação estratégica das empresas dentro dos arranjos locais, estas podem se associar ao poder público local e às instituições locais na proposição de projetos de desenvolvimento da estrutura produtiva.

Neste caso, o ambiente institucional pode ser de fundamental importância para o desenvolvimento do processo inovativo. As instituições são as regras que delimitam as escolhas do indivíduo numa sociedade, elas dão forma à interação social que se configura numa sociedade, podendo ser regras formais (sistema judiciário, direitos de propriedade, leis trabalhistas, leis de patentes etc.) ou informais como códigos de conduta, confiança, disposição à cooperação etc. A importância destas regras informais é sentida principalmente se pensarmos que as mesmas leis têm efeitos diferentes em diferentes países e que os clusters dos países em desenvolvimento possuem relações de cooperação inferiores aos clusters nos países desenvolvidos.

As instituições vão limitar as estratégias das organizações na busca dos seus objetivos, sendo fundamental na diminuição das incertezas que surgem nas relações sociais e econômicas, como a falta de informação, os custos na formação de contratos, os gastos judiciários etc. Portanto, as instituições podem diminuir os custos de transação, possibilitando maior eficiência nas relações entre os agentes e modificando as expectativas de risco por proporcionar segurança e estabelecer garantias entre as firmas.

\subsubsection{Os Sistemas de Inovação.}

Apesar dos sistemas de inovação poderem envolver diversos setores, e não necessariamente possuírem uma definição geográfica, os clusters podem favorecer o surgimento de sistemas regionais de inovação nos locais em que se encontram.

Os sistemas de inovação podem ser vistos como redes de relações institucionais, formais e informais, que dão sustentação ao desenvolvimento tecnológico, podendo ser de caráter nacional, regional e até mesmo supranacional. Os sistemas de inovação podem surgir pela interação entre as firmas, a universidade e os órgãos públicos, sendo de grande utilidade o papel que o governo pode desempenhar na aproximação entre seus membros. A estrutura institucional, as relações sociais e a qualidade da cooperação entre os agentes poderão 
inibir ou incentivar a promoção do desenvolvimento tecnológico e do funcionamento destes sistemas.

O conceito de Sistema Nacional de Inovação em Nelson (1993), Freeman (1995) e Lundvall (1992) apud Garcez (2000) trata o processo de inovação de uma forma interativa, buscando definir de que forma o ambiente industrial, político, institucional e até mesmo cultural poderiam atuar sobre o processo de inovação. O Sistema Nacional de Inovação ${ }^{12}$ seria formado por todo o aparato institucional cujas interações resultam nas inovações tecnológicas.

Peter NijKamp apud Bertuglia et alii (1995), falando sobre os aspectos espaciais da inovação, ressalta a conecção que há entre as atividades de inovação e a dinâmica espacial, ambas se influenciando. Se por um lado, o processo de inovação pode alterar o desenvolvimento do espaço, com grandes efeitos sobre o processo de crescimento regional, por outro lado, a concentração geográfica da atividade econômica e a existência de um sistema de comunicação eficiente pode significar melhores informações e difusão sobre novas invenções e adoção destas inovações, estimulando o crescimento e novos tipos de atividade. Portanto, há uma forte relação entre dinâmica espacial, infra-estrutura pública, atividades de $\mathrm{P} \& \mathrm{D}$ e difusão de inovação.

Para o autor, as inovações seriam mais prováveis de acontecer em aglomerações maiores. No entanto, Nijkamp ressalta que a atividade de inovação nos EUA vem declinando especialmente nas maiores áreas urbanas, o que seria explicado pelo que chamou de deseconomias de tamanho, ou seja, ao atingir um certo grau de aglomeração haveria um congestionamento que diminuiria o potencial inovativo.

Na análise que Freeman apud Dosi (1988) faz sobre os fatores que potencializam a geração das inovações, ele ressalta, como vários outros autores, a importância das trocas de conhecimento entre as empresas, das relações destas com o governo e do papel fundamental que as políticas públicas podem ter no sistema de inovação como agente catalisador de informações externas. O autor também salienta que a incorporação das inovações dependerá em grande parte do aparato institucional formal e informal externo à firma.

\footnotetext{
12 A inovação é a incorporação do conhecimento a novos produtos e processos. Inovação tecnológica de processo é a adoção de métodos de produção tecnologicamente novos ou melhorados, incluindo formas de comercialização de produtos, podendo envolver mudanças nos equipamentos, na organização da produção etc. As inovações podem envolver tecnologias radicalmente novas, bem como ser baseadas em combinações de tecnologias existentes em novos usos (Silva, 2000).
} 
O ambiente institucional e as políticas públicas influenciariam no crescimento das empresas, podendo estimular as inovações para a manutenção da competitividade das firmas. Para facilitar a transferência do conhecimento tecnológico da universidade para o mercado poderia se fazer uso de agências de apoio que promovam a interação entre universidade e empresa, estas agências seriam importantes por poderem diminuir os custos de transação na aquisição de novas tecnologias.

A atenção ao desenvolvimento tecnológico está embasada na importância que este assume para a competitividade e o crescimento da economia de um país. Neste aspecto, os sistemas regionais de inovação são importantes para o desenvolvimento tecnológico porque são nestes níveis que ocorrem a relação entre as firmas, as universidades, os laboratórios de pesquisa, as entidades governamentais etc.

Kumar e Siddarthan (1997) apontam para a importância da intervenção governamental nos países industrializados na área tecnológica, especialmente de novas tecnologias, tomando a forma de P\&D nos laboratórios públicos, ou em empreendimentos subsidiados, pela formação de consórcios de pesquisa etc. Mas, segundo os autores, apesar da tecnologia ter recebido especial atenção nos países desenvolvidos por parte dos governos federais e até mesmo locais, ela ainda não é considerada com grande atenção nas políticas dos países em desenvolvimento, negligência que só aumenta a defasagem entre os países ricos e pobres, principalmente na área de ciência e tecnologia.

Para estes autores, dado que as novas tecnologias têm aplicações em vários setores da atividade econômica, a falta de capacidade dos países em desenvolvimento em obterem capacidade tecnológica pode ter sérias implicações para a sua competitividade externa. Os países deveriam se preocupar em criar capacidade de produção tecnológica, e não apenas se contentarem em empregar as tecnologias disponíveis no mundo pelo processo de transferência porque, caso contrário, a sua própria capacidade de usar o que já existe, ou seja, de copiar, pode ficar comprometida. Além disso, o aumento da capacidade tecnológica dos países em desenvolvimento pode ser muito importante para expandir a sua capacidade de exportação.

Apesar das considerações feitas por Kumar e Siddarthan (1997), os resultados de um estudo empírico realizado por Peter Nijcamp apud Bertuglia et alii (1995) apontam para o fato de que o fator tecnológico é importante para explicar as exportações dos países desenvolvidos mas não se mostra significativo para a exportação dos países subdesenvolvidos. Segundo o trabalho de Nijkamp, um acréscimo no fator tecnológico só é 
relevante para explicar o comércio exterior nos países subdesenvolvidos se não se considera os setores de alta tecnologia que são dominados pelos países desenvolvidos. Este resultado faz sentido se pensarmos que um incremento tecnológico nos setores de alta tecnologia nos países subdesenvolvidos muitas vezes significa apenas equiparar-se ao que já existe nos países mais avançados. Além disso, pode implicar aumento de importações no curto prazo.

Quanto ao tamanho e a nacionalidade das empresas, Nijcamp acredita que, pela perspectiva de se construir uma capacidade tecnológica local, a consolidação de grandes empreendimentos teria um efeito maior que a fragmentação da capacidade produtiva em numerosos pequenos negócios. Mas, segundo o autor, apesar de serem as grandes empresas que dariam a diferença visível na capacidade tecnológica do país, as atividades tecnológicas das pequenas e médias empresas também poderiam ser importantes, devendose encorajar as relações verticais entre as grandes firmas e as firmas menores de modo que haja uma maior difusão tecnológica.

A presença de grandes empresas ou de filiais de multinacionais poderia ser importante para a transferência tecnológica por estarem articuladas com as pequenas e médias empresas na rede de cooperação e desenvolvimento de projetos. A tecnologia importada poderia servir de estímulo aos processos de aprendizagem (Kumar e Siddarthan, 1997).

No entanto, Cassiolato et alii (1998) alertam para o fato de que a participação das multinacionais pode ter um efeito negativo sobre a capacidade local de inovação por reduzir as atividades em $\mathrm{P} \& \mathrm{D}$, passando-as para a matriz no exterior, e ainda ressalta que estas empresas geralmente têm pouco envolvimento com as redes locais de inovação, o que mais uma vez reduz a capacidade local de investimento em P\&D e os efeitos encadeadores das redes de cooperação.

Fernandes et alii (2000) descrevem um modelo de organização da produção proposto por Boyer (1989) cujas características seriam: a otimização global dos fluxos produtivos; a integração entre pesquisa, desenvolvimento e produção da firma; a descentralização de decisões de produção para unidades inferiores e menos hierárquicas; a constituição de redes de firmas em busca dos ganhos de especialização e coordenação; a subcontratação de longo prazo e a busca de cooperação para o desenvolvimento conjunto de inovações tecnológicas. Para a autora, este modo de organização deveria ser levado em consideração quando da proposição de políticas regionais de desenvolvimento. 
As políticas públicas deveriam ser reformuladas levando-se em consideração o dinamismo que a inovação traz para o crescimento da economia. A autora cita ainda o trabalho de Cooke et alii (1998) segundo o qual a inovação responde por $90 \%$ dos ganhos de produtividade nas economias avançadas, sendo que os ganhos de produtividade seriam responsáveis por $80 \%$ do crescimento do PIB, ou seja, a inovação seria a maior fonte de crescimento da economia.

Um desafio para as políticas de desenvolvimento regional seria contribuir para a organização da economia regional em redes de cooperação ${ }^{13}$, importantes para se ter um sistema local de inovação. A organização em rede poderia diminuir o risco dos investimentos tecnológicos, tornando certos investimentos viáveis para firmas de pequeno porte, diminuindo as imperfeições do mercado e aumentando a capacidade de inovação. No entanto, a formação destes clusters ou dos pólos tecnológicos como estratégia de desenvolvimento regional não é algo fácil de ser implementado. Esta tentativa pode significar esforços significativos de políticas públicas regionais com resultados apenas no longo prazo, por depender de fatores como a cultura empresarial e a confiança mútua, base das relações de cooperação, que demandam tempo para serem sedimentados. Além disso, deve-se considerar que os efeitos das políticas locais dependerão das políticas nacionais, tanto políticas macroeconômicas, como políticas industriais.

\footnotetext{
${ }^{13} \mathrm{O}$ foco de atenção deixa de ser a PME isolada e passa a ser as redes de PMEs localizadas em um mesmo espaço com a introdução do conceito de distrito industrial por Becattini (1978).
} 


\section{Capítulo 2}

\section{A Indústria de Equipamentos Médicos, Hospitalares e Odontológicos (EMHO).}

Neste capítulo abordamos de forma geral a indústria de equipamentos médicos, hospitalares e odontológicos no Brasil e no mundo. Para a indústria no Brasil, apresentamos dados como o tipo de segmentação do setor, a evolução do produto, a composição do capital, o porte das empresas etc. Entretanto, há uma série de dificuldades na análise deste setor devido à falta de dados bibliográficos.

No final do capítulo, levantamos algumas questões relacionadas às aquisições do setor público, por consideramos ser assunto relevante para o setor.

\subsection{A indústria de equipamentos médicos, hospitalares e odontológicos no Mundo.}

A indústria de equipamentos médicos, hospitalares e odontológicos incorpora duas lógicas industriais bastante distintas: desde as grandes empresas multinacionais altamente capacitadas tecnologicamente que competem por sofisticação e possuem grande diversidade de produtos, até empresas pequenas, geralmente especializadas em alguns produtos, várias delas de base tecnológica.

O fato da demanda por saúde ter uma baixa elasticidade de substituição determina uma oferta, por parte das grandes empresas, de equipamentos altamente sofisticados, geralmente com acréscimos marginais nas propriedades dos produtos, mas com grandes diferenciais de preços. Além da demanda ser favorável a este tipo de "estratégia da sofisticação", o setor é estimulado pelo dinamismo tecnológico de diversos outros setores tais como o setor da mecânica de precisão, da eletrônica digital, o setor de informática, o setor químico etc. (Furtado, s/d).

A estratégia de comercialização das grandes empresas pode significar uma importante barreira de mercado para as empresas menores. As grandes empresas são capazes de oferecer pacotes fechados que incluem, além do equipamento, uma variedade de programas de softwares, os serviços de assistência técnica e vários planos de financiamento, inclusive de leasing. Além disso, como o uso dos equipamentos está associado à necessidade de reposição periódica de alguns insumos de parte dos equipamentos ou de produtos químicos fornecidos pelo produtor, cria-se uma dependência prolongada entre fornecedores e consumidores. 
Segundo Furtado, a estratégia das grandes empresas de se associarem a empresas menores que possuam tecnologia complementar pode ser interessante para as empresas menores por permitir a estas um salto de produção e uma política de comercialização mais agressiva. Além disso, os custos de promoção de vendas no exterior, de assistência, de certificação dos produtos, entre outros, fazem com que haja grande movimento de fusões e aquisições neste setor.

Conforme dados do Ministério da $\operatorname{Saúde}^{14}$, o mercado mundial da indústria de equipamentos médicos está em torno de 105 bilhões de dólares e vem apresentando um crescimento médio de 2,5\% nos últimos anos. Conforme estudo do governo dos EUA, o mercado norte-americano representa $45 \%$ do mercado mundial, o Japão $18 \%$, a Alemanha $11 \%$ e a França 5\%. Estes 4 países representam 79\% do mercado mundial de EMH.

Os EUA têm a principal indústria de equipamentos médicos do mundo com $45 \%$ da produção mundial. O crescimento da indústria de equipamentos médico-hospitalares nos EUA desde 1987 foi de 8,4\% ao ano. A produção dos EUA foi de 68,8 bilhões de dólares, com uma demanda interna de 62,2 bilhões de dólares em 1998, sendo que $11 \%$ do consumo são supridos pelas importações e $22 \%$ da produção são para exportação. (Ministério da Saúde, 2000).

Entre os principais fatores do crescimento da indústria e do comércio norte-americanos de equipamentos médicos e hospitalares estão: a composição etária dos EUA; o crescimento da economia norte-americana; o crescimento das economias em desenvolvimento; a capacidade tecnológica das empresas; e finalmente, a capacidade institucional dos EUA de regulação do mercado doméstico e de atuação no acesso aos mercados externos. Quanto a este último aspecto, a divisão de equipamentos médicos do Departamento de Comércio dos EUA fornece informações e serviços na abertura de mercados e na remoção das barreiras comerciais, criando novas oportunidades comerciais para as empresas norte-americanas (U.S. Department of Commerce, www.doc.gov).

Como consequência do potencial desta indústria nos EUA, o país apresenta um superávit elevado e sistemático neste setor, principalmente com a União Européia, o Canadá e o Japão. Esta liderança das empresas norte-americanas se mantém em parte por elas conseguirem exportar também sua cultura médica para os outros países.

\footnotetext{
${ }^{14}$ O Setor Saúde e o Complexo da Saúde no Brasil. UNICAMP. Núcleo de Estudos de Políticas Públicas, 2000.
} 
Entre as 20 maiores empresas do mundo neste setor, 13 são originárias dos EUA. Mas Furtado observa que, como parte das exportações das empresas norte-americanas são realizadas a partir de bases produtivas estabelecidas em outros países, o predomínio norteamericano deve ser ainda maior que as estatísticas de comércio. A internacionalização da produção neste setor pode ocorrer por empresas que buscam produzir em países que apresentam custos menores, por empresas que vão em busca de representação em um grande mercado consumidor ou por empresas que vão em busca da capacidade tecnológica existente em um país através de um acesso mais direto e próximo. Este último motivo pode ser o caso de muitas empresas européias e japonesas instaladas nos EUA. Segundo documento do Ministério da Saúde, quase 200 empresas estrangeiras instalaram uma filial nos EUA.

A competitividade de cada país pode variar muito conforme o subsetor da indústria médica em que está inserido o seu produto. Como exemplo desta diversidade de produtos podemos citar o caso da Alemanha que fornece apenas 6,3\% das importações japonesas no setor como um todo, mas exporta $44 \%$ dos equipamentos de diagnósticos usados no Japão (Furtado, s/d). Estas diferenças nos mostram que há espaço para a especialização em setores nos quais o país possa criar vantagens competitivas. Além disso, a Alemanha exporta $25,7 \%$ dos equipamentos odontológicos importados no Japão. A Holanda também tem uma participação muito pequena na pauta de importações japonesas em equipamentos médicos e hospitalares, mas fornece $1 / 3$ dos equipamentos de diagnóstico por imagem importados pelo Japão.

A Alemanha e o Japão são os principais competidores dos EUA. A Alemanha é especializada em equipamentos de imagens e implantes e o Japão em equipamentos radiológicos e de ultra-som. Países como a Coréia do Sul e Taiwan tem ingressado em algumas faixas de produtos desta indústria. A entrada destes países é importante para o Brasil por permitir uma nova fonte de fornecedores.

No Japão a taxa de crescimento da indústria de equipamentos médicos e hospitalares está em torno de $2,2 \%$ nos últimos anos, taxa maior que o ritmo de crescimento da economia japonesa como um todo. Este é um dos poucos setores em que o Japão apresenta déficit com os EUA.

$\mathrm{Na}$ França a indústria de equipamentos médicos e hospitalares é formada por 250 empresas com um total de 20.000 funcionários e vendas médias de 8 milhões de dólares. A maioria 
destas empresas é especializada em apenas um produto e metade das 20 maiores são filiais de empresas estrangeiras.

O Canadá (Quebec) tem uma indústria de equipamentos médicos e hospitalares de tamanho mais modesto formada por 200 empresas, na maioria de pequeno porte, que empregam um total de 4.000 pessoas. Estas empresas são responsáveis por uma produção total de 300 milhões de dólares e exportam $40 \%$ da produção.

\subsection{A indústria de equipamentos médicos, hospitalares e odontológicos no Brasil.}

Segundo estimativas da ABIMO (Associação Brasileira da Indústria de Artigos e Equipamentos Médicos, Odontológicos, Hospitalares e de Laboratórios), a indústria brasileira de EMHO é formada por cerca de 500 empresas, sendo 13\% de microempresas, $16 \%$ de pequenas empresas, $55 \%$ são empresas de médio porte e $16 \%$ de empresas de médio a grande porte. Como se pode observar, existe uma concentração muito grande na média empresa que representaria aproximadamente $\mathrm{R} \$ 15$ milhões de faturamento. $\mathrm{O}$ Estado de São Paulo abriga $80 \%$ das empresas deste setor e na região de Ribeirão Preto tem-se 50 empresas do setor entre micro, pequenas e médias empresas, ou seja, $10 \%$ da indústria nacional do setor.

Até a década de 90, o setor de equipamentos médicos, hospitalares e odontológicos era classificado pelo IBGE em quatro grupos conforme a complexidade tecnológica em:

I - aparelhos não elétricos e eletrônicos: instrumentos cirúrgicos, estetoscópios, aparelhos para medir a pressão arterial, termômetros etc.

II - aparelhos elétricos e eletrônicos, partes e acessórios: aparelhos de anestesia, eletromédicos e monitoração, aparelhos de raio $\mathrm{X}$ e componentes, aparelhos de diagnóstico por imagem, equipamentos de laboratório, hemodialisadores, oxigenadores, aparelhos odontológicos etc.

III - aparelhos de prótese e órtese: válvulas cardíacas, pernas e membros artificiais, aparelhos de correção da surdez, marcapassos cardíacos, parafusos e dentes acrílicos, olhos artificiais etc.

IV - material de consumo: agulhas e seringas, algodão e gases, categutes, sondas e catéteres, luvas cirúrgicas, reagentes etc. (Souza et alii, 2000). 
A partir da década de 90 o IBGE passa a adotar o CNAE (Cadastro Nacional de Atividades Econômicas) e os três primeiros grupos da antiga classificação ficam reunidos em apenas um grupo denominado por CNAE 33.1, com a denominação de aparelhos e instrumentos para usos médico-hospitalares, odontológicos e de laboratórios e aparelhos ortopédicos. O grupo IV da antiga classificação passa a fazer parte do setor farmacêutico na classe CNAE 24.54-6, denominado por fabricação de materiais para usos médicos, hospitalares e odontológicos.

Entretanto, a forma mais frequente de classificação é a que segue a classe terapêutica adotada pela ABIMO que classifica as empresas desta indústria em:

- Setor de Implantes e Material de Consumo Médico-Hospitalar - fabricantes de produtos implantáveis, tais como próteses ortopédicas, cardíacas, neurológicas, mamárias etc. e fabricantes de materiais de consumo médico-hospitalares hipodérmicos tais como: têxteis, adesivos e outros de uso único.

- Setor de Equipamentos Médico-Hospitalares - empresas fabricantes de eletromédicos, mobiliários hospitalares, instrumentais cirúrgicos, equipamentos fisioterápicos, cozinhas e lavanderias hospitalares.

- Setor de Odontologia - fabricantes de equipamentos odontológicos (consultórios completos), materiais de consumo (resinas, amalgamas e outros) e de implantes odontológicos.

- Setor de Radiologia e Diagnóstico por Imagem - empresas fabricantes de equipamentos para $\mathrm{RX}$, processadores filmes (diagnóstico), e de consumo.

- Setor de Laboratórios - empresas fabricantes de equipamentos para laboratórios, reagentes e outros.

Segundo Souza et alii (2000) a indústria de insumos e equipamentos médicos e hospitalares teve início no Brasil a partir dos anos 50 com a produção de materiais de consumo como seringas e agulhas e aparelhos de anestesia. Nos anos 60 surgiram as primeiras fábricas de instrumentos cirúrgicos. Mas foi na década de 70 que esta indústria deu um salto qualitativo com a produção de aparelhos eletro-eletrônicos e de materiais de consumo. Nesta época instalaram-se a indústria de aparelhos e filmes de raio $\mathrm{X}$, de instrumentos de laboratório, de instrumentos de monitoração, de dialisadores e oxigenadores, de válvulas cardíacas e marcapassos. 
Houve um grande aumento de produção durante as décadas de 70 e 80 . Os grupos I, II e III, da antiga classificação do IBGE, aumentaram sua participação no setor em detrimento do grupo IV. Este aumento foi devido principalmente ao processo de substituição de importações. Mas apesar da expansão da produção nacional, os equipamentos mais complexos como os aparelhos de raio $\mathrm{X}$ de maior porte, os aparelhos de diagnóstico por imagem (ultra-som, tomografia computadorizada, RNM) e certos aparelhos de laboratório continuam sendo importados.

Para os autores, a política de reserva de mercado do setor de instrumentação médica nas décadas de 70 e 80 não teve seus resultados esperados. Entre os segmentos analisados por estes autores, que foram os setores de laboratórios complexos, marcapassos, ultra-som e monitores cardíacos, os resultados desta política só se mostraram positivos no segmento de monitores, onde já existia uma capacidade tecnológica local. Nos demais segmentos, as empresas nacionais tiveram grandes dificuldades de ofertarem produtos sofisticados, sobretudo a partir de tecnologia gerada endogenamente.

Em parte, estas dificuldades ocorreram devido ao grande avanço da fronteira tecnológica internacional a partir do final da década de 70 e pela rápida difusão das tecnologias de informática e de novos materiais. Entretanto, apesar destas limitações tecnológicas, a industrialização por substituição de importações foi muito importante para o crescimento desta indústria no país, com um crescimento médio de $12,25 \%$ ao ano durante a década de 70 , e crescimento mais moderado durante a década de 80 .

\begin{tabular}{|c|c|c|c|c|c|c|}
\hline \multicolumn{7}{|c|}{ Tabela 2.1} \\
\hline \multicolumn{7}{|c|}{ Evolução do Produto (mil US\$ 1985) e do Pessoal Ocupado da Indústria de EMH } \\
\hline & & Grupo I & Grupo II & Grupo III & Grupo IV & Total \\
\hline 1970 & $\begin{array}{l}\text { Valor adicionado } \\
\text { Composição setorial (\%) } \\
\text { Pessoal Ocupado }\end{array}$ & $\begin{array}{l}7.492 \\
12,04 \\
1.115\end{array}$ & $\begin{array}{l}9.281 \\
14,92 \\
1.039\end{array}$ & $\begin{array}{c}1.774 \\
2,85 \\
463\end{array}$ & $\begin{array}{c}43.659 \\
70,19 \\
4.066\end{array}$ & $\begin{array}{c}62.205 \\
100,00 \\
6.683\end{array}$ \\
\hline 1975 & $\begin{array}{l}\text { Valor adicionado } \\
\text { Composição setorial (\%) } \\
\text { Pessoal Ocupado }\end{array}$ & $\begin{array}{l}16.681 \\
12,63 \\
1.767\end{array}$ & $\begin{array}{c}20.463 \\
15,49 \\
1.679\end{array}$ & $\begin{array}{c}4.276 \\
3,24 \\
761\end{array}$ & $\begin{array}{c}90.690 \\
68,65 \\
5.983\end{array}$ & $\begin{array}{c}132.109 \\
100,00 \\
10.190\end{array}$ \\
\hline 1980 & $\begin{array}{l}\text { Valor adicionado } \\
\text { Composição setorial (\%) } \\
\text { Pessoal Ocupado }\end{array}$ & $\begin{array}{c}25.719 \\
13,01 \\
2.383\end{array}$ & $\begin{array}{c}47.258 \\
23,9 \\
3.329\end{array}$ & $\begin{array}{c}6.658 \\
3,37 \\
1.263 \\
\end{array}$ & $\begin{array}{c}118.096 \\
59,53 \\
7.411\end{array}$ & $\begin{array}{c}197.732 \\
100,00 \\
14.386\end{array}$ \\
\hline 1985 & $\begin{array}{l}\text { Valor adicionado } \\
\text { Composição setorial (\%) } \\
\text { Pessoal Ocupado }\end{array}$ & $\begin{array}{c}53.474 \\
17,7 \\
2.961\end{array}$ & $\begin{array}{c}65.715 \\
21,7 \\
3.948\end{array}$ & $\begin{array}{c}48.964 \\
16,2 \\
1.511\end{array}$ & $\begin{array}{c}134.651 \\
44,4 \\
8.552\end{array}$ & $\begin{array}{c}302.804 \\
100,00 \\
17.249\end{array}$ \\
\hline
\end{tabular}

Fonte: IBGE Censos Industriais, em Souza et alii, 2000. 
Na década de 90, além do esgotamento do processo de substituição de importações, as empresas nacionais passam a sofrer uma forte concorrência dos importados devido à abertura comercial já no início da década. No entanto, a produção de equipamentos médicos cresceu consideravelmente ao longo da década de 90, principalmente após o Plano Real com a expansão da demanda interna. Ocorreu também uma certa tendência à especialização. Muitos produtos deste setor deixaram de ser produzidos localmente por causa da competição dos importados, é o caso dos marcapassos implantáveis, de certos aparelhos mais complexos para laboratório e dos aparelhos de radiologia. Muitos produtos nacionais tinham o preço de três a quatro vezes maior que os importados. Entretanto, nenhuma das grandes multinacionais se instalou no país nesse período, a principal via de acesso ao mercado interno continuou sendo as importações.

Parte do conhecimento do desempenho deste setor ao longo da década ficou obscurecido devido à interrupção dos censos do IBGE para a indústria médica desde 1996. Para Souza et alii (2000), atualmente a ABIMO seria a instituição com as estatísticas mais regulares, apesar dos seus dados provavelmente estarem superestimados quanto às condições das empresas do setor ${ }^{15}$. Estes autores usam os dados fornecidos pela PAEP (Pesquisa da Atividade Econômica Paulista). Segundo esta instituição, em 1996 havia 355 empresas de equipamentos médicos no Estado de São Paulo, que tiveram uma receita líquida de 586 milhões de reais e $77,5 \%$ do faturamento deste setor vinha do segmento de instrumentos médicos, que veio crescendo ao longo da década.

O número de empresas apresentados pela PAEP seria bastante coerente com o da ABIMO (de 500 empresas para o setor), poderíamos pensar que 356 estariam no Estado de São Paulo e o restante, para completar as 500 empresas, estariam nos outros Estados.

\section{Tabela 2.2}

\section{Dados de Faturamento e Pessoal Ocupado da Indústria de Equipamentos Médicos}

\begin{tabular}{|l|c|c|c|c|c|c|c|}
\hline \hline & $\mathbf{1 9 8 8}$ & $\mathbf{1 9 9 0}$ & $\mathbf{1 9 9 2}$ & $\mathbf{1 9 9 4}$ & $\mathbf{1 9 9 6}$ & $\mathbf{1 9 9 7}$ \\
\hline \hline Valor da produção (milhões US\$) & 857 & 960 & 709 & 1.311 & 1.961 & 2.301 \\
\hline \hline Pessoal ocupado & 38.126 & 48.991 & 41.482 & 44.269 & 63.702 & \\
\hline Coeficiente de exportação & 5,3 & 7,3 & 17,3 & 15,5 & 10,1 \\
\hline
\end{tabular}

Fonte: ABIMO em Souza et alii, 2000.

\footnotetext{
${ }^{15}$ A ABIMO possui cerca de 223 associados dos quais em torno de 70 respondem às pesquisas, nesta amostra estão as empresas mais importantes do setor.
} 


\section{Tabela 2.3}

\begin{tabular}{|l|c|c|c|}
\multicolumn{2}{|c|}{ Indicadores Econômicos da Indústria Paulista de Equipamentos Médicos (1996) } \\
\hline \multicolumn{1}{|c|}{ CNAE 24.54-6 } & CNAE 33.1 & Total equip. médicos \\
\hline Receita líquida (R\$) & 132.106 .209 & 454.439 .797 & 586.546 .006 \\
\hline Valor adicionado (R\$) & 85.535 .095 & 282.495 .429 & 368.030 .524 \\
\hline$N^{\circ}$ de empresas (n ${ }^{\text {abbs.) }}$ & 79 & 277 & 356 \\
\hline Pessoal ocupado (n ${ }^{\circ}$ abs.) & 3.413 & 10.085 & 13.498 \\
\hline Pessoal/empresa & 43 & 36 & 38 \\
\hline
\end{tabular}

Fonte: PAEP - SEADE em Souza et alii, 2000.

Conforme os dados da ABIMO, o setor teve um faturamento de $\mathrm{R} \$ 3.450 .098 .000,00 \mathrm{em}$ 2000. Além disso, o valor das exportações naquele ano foi de US\$ $149.901 .439,00$ e as importações foram de US\$ 811.665.418,00. O número de empregos diretos foi de 37.680.

Segundo a ABIMO, quase $80 \%$ das empresas de equipamentos médicos, hospitalares e odontológicos no Brasil são de capital nacional. Ainda segundo esta instituição, os clientes deste setor são divididos em partes iguais entre o setor público e privado. Mas para Souza et alii (2000) estes dados podem não ser realistas por não considerarem mudanças importantes ao longo da década de 90 como a grande expansão do setor privado e a retração dos gastos do SUS. Segundo o autor, em 1998 o SUS realizou gastos totais de 8,3 bilhões de reais enquanto os gastos no sistema de seguros privados foram de US\$ 16 bilhões.

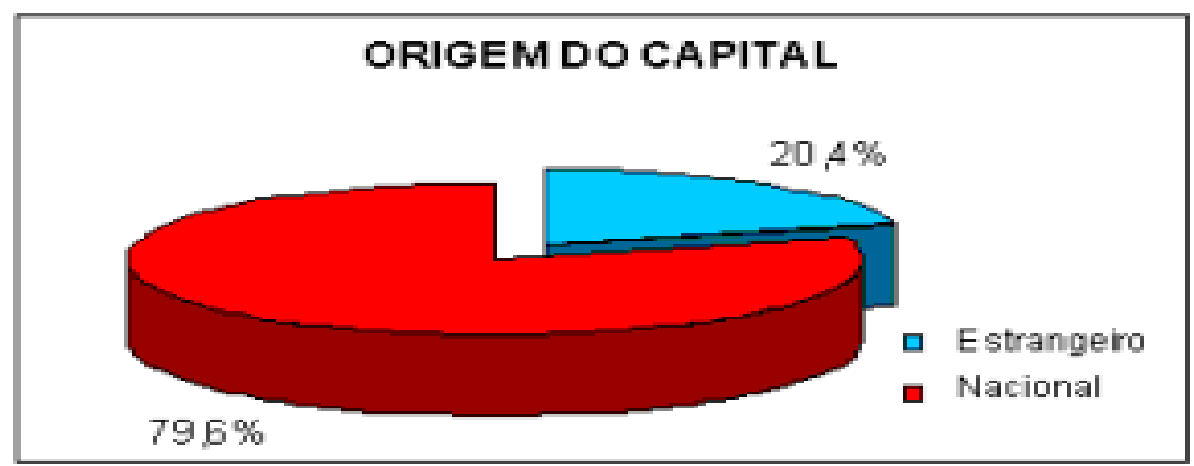

Fonte: ABIMO. 


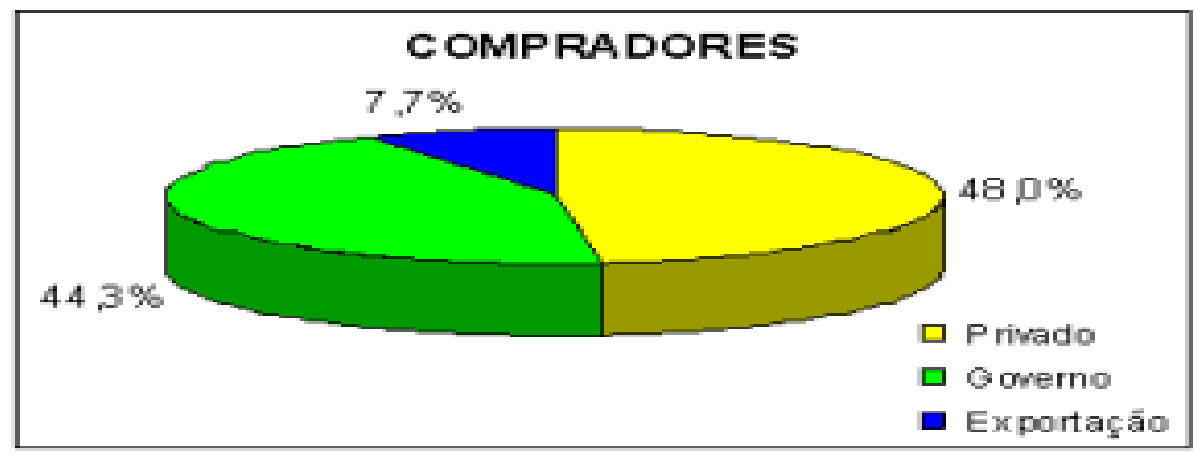

Fonte: ABIMO.

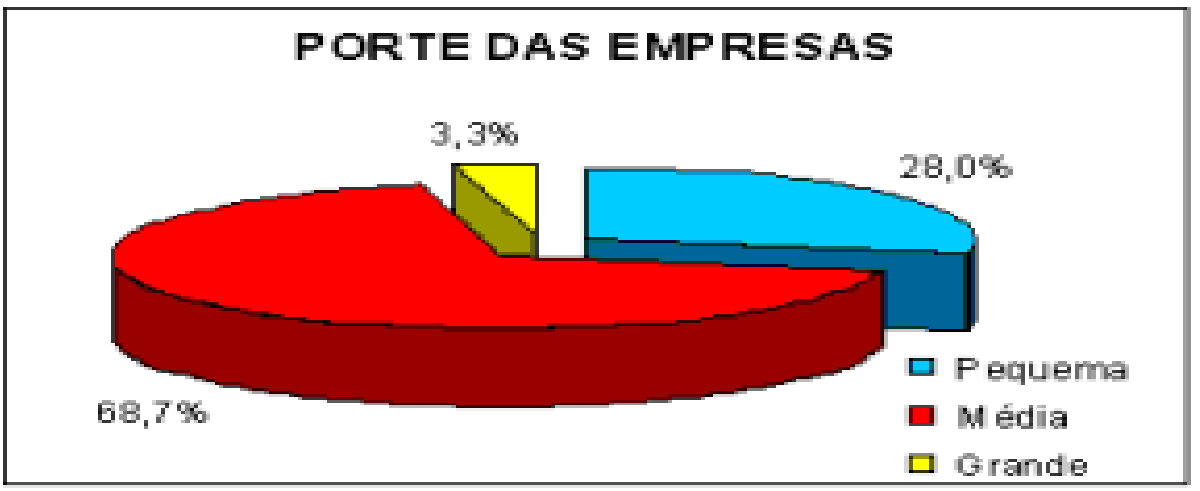

Fonte: ABIMO.

Segundo Souza et alii (2000) as empresas em média destinam $91,2 \%$ da produção para o mercado interno. A maioria das empresas nacionais seria de pequeno e médio porte, com aproximadamente 33 funcionários em média (PAEP). Além disso, a grande dificuldade de crescimento da empresa nacional está na falta de capacidade em oferecer financiamento de longo prazo aos clientes, estratégia que é adotada pelas empresas estrangeiras. As formas de pagamento mais usadas pelo setor no Brasil seriam: o pagamento a vista; o financiamento direto pelas próprias empresas; e em terceiro lugar o leasing bancário e o financiamento pelo FINAME do BNDES.

De acordo com estes autores, a pesquisa da PAEP indica o setor de instrumentação, do qual fazem parte grande parte das empresas de equipamentos médicos no Estado de São Paulo, como o segundo setor industrial com maior índice de inovação. De todas as empresas do setor no Estado de São Paulo quase 43\% disseram ter introduzido algum tipo de inovação tecnológica de produto ou processo entre 1994 e 1996.

Os dados da PAEP ainda mostram que durante a década de 90 houve uma diminuição nas inovações radicais, talvez pela competição dos importados que inibiu a entrada das empresas nacionais nos segmentos de maior dinamismo tecnológico. Por outro lado, houve 
um aumento das inovações periféricas com lançamento de novos produtos e aumento da produtividade através de incorporação de novos processos e inovações organizacionais. Estas inovações ocorreram basicamente por imitação de tecnologias já existentes.

Entre as principais fontes de inovação tecnológica das empresas do setor estão, em ordem decrescente de importância: o conhecimento interno (engenharia reversa), os contatos informais nas feiras e em outros eventos, a presença dos concorrentes e, por fim, os fornecedores, porque muitas vezes as novas tecnologias são geradas pelos fornecedores e transmitidas ao setor de equipamentos de saúde. As relações com a universidade são menos citadas, podendo ser uma fonte riquíssima ainda pouco explorada.

Enfim, os efeitos positivos da abertura comercial para a indústria nacional de EMH teriam sido a especialização e o aumento da produtividade e do ritmo de inovações. Mas a abertura comercial, por outro lado, causou um grande efeito negativo na Balança Comercial com um aumento gigantesco das importações.

Segundo Souza et alii (2000), de modo geral o desempenho das exportações foi positivo, afetando mais favoravelmente os setores que tinham um pouco mais de complexidade tecnológica. As exportações tiveram um crescimento considerável de 168\% entre 1989 e 1995. Entre os fatores que explicam esta evolução das exportações estariam a facilidade nas importações de partes e componentes, que reduziram o custo do produto final, a especialização das empresas e a introdução de inovações organizacionais. Entretanto, a valorização cambial na segunda metade da década diminuiu o ritmo de crescimento das exportações. Mas, posteriormente a desvalorização cambial contribuiu novamente para as exportações deste setor.

Por outro lado, as importações tiveram um crescimento de 339\% entre 1989 e 1998, saltando de US\$ 272 milhões em 1989 para US\$ 1,2 bilhão em 1998. O valor das importações em 1998 foram 7,25 vezes maior que o melhor desempenho das exportações em 1995. O aumento das importações ocorreu de maneira semelhante em todos os segmentos deste setor. Estima-se que atualmente as importações atendam à metade da demanda interna por produtos médico-hospitalares e odontológicos. Este valor era apenas de $25 \%$ da demanda interna na década de 80 . 


\subsection{Aquisições do Setor Público.}

$\mathrm{Na}$ maioria dos setores industriais o avanço tecnológico traz aumento de eficiência com redução dos custos, mas no setor de equipamentos médicos o incremento tecnológico muitas vezes é somado à tecnologia anterior, o que causa custos crescentes destes equipamentos. Por isso, ao falarmos em indústria de equipamentos médicos devemos nos questionar sobre o tipo de avanço industrial e tecnológico que estamos buscando.

Pode-se pensar em uma estratégia de produção nacional de equipamentos mais simples e de uso geral, de acordo com as necessidades locais, não se investindo tanto em sofisticações desnecessárias e acessórios que sejam muito pouco utilizados. Esta estratégia pode reduzir em muito o custo dos equipamentos, não significando necessariamente perda de qualidade dos produtos.

Esta não é uma estratégia inteiramente nova no mundo, em vários países com necessidades de universalizar seus serviços de saúde, novas tecnologias têm sido aproveitadas na elaboração de produtos mais simples, menores e com maior mobilidade, favorecendo uma grande redução nas despesas do sistema de saúde.

A política de saúde do país pode influenciar na capacidade de entrada das empresas nacionais no mercado. A demanda do setor público pode ser fundamental para a produção deste novo tipo de produto uma vez que o setor público é o maior cliente desta indústria. Um grande obstáculo destas empresas são as grandes compras governamentais sem planejamento, o que impossibilita que as empresas nacionais participem da concorrência, além de existir um certo preconceito com os produtos nacionais, devido a uma influência muito forte das empresas estrangeiras.

Outra questão importante é que a falta de informação por parte do governo sobre o parque de equipamentos e a falta de planejamento nas aquisições têm levado a três problemas principais: em primeiro lugar, a uma grande concentração dos mesmos equipamentos em locais muito próximos; em segundo lugar, ao excesso de gastos com o setor da saúde; e finalmente, tem levado a constantes desequilíbrios na balança comercial. Veremos cada um destes casos de forma mais detalhada.

Primeiramente, o excesso de oferta destes equipamentos muitas vezes pode provocar uma demanda forçada e desnecessária de procedimentos médicos, principalmente em diagnósticos efetuados com equipamentos de alto custo e com elevados custos de manutenção. 
Segundo estudos do Ministério da Saúde ${ }^{16}$, o número estimado de mamógrafos no Brasil daria para atender a uma população de 376,8 milhões de pessoas. Outro exemplo deste exagero é o fato de que na cidade de Belo Horizonte existem 45 tomógrafos, enquanto na cidade de Paris, para uma população semelhante à capital mineira, há apenas 6 tomógrafos. O Ministério da Saúde estima que até $40 \%$ do parque instalado de equipamentos do setor público esteja sub-utilizado ou inoperante em decorrência da completa falta de planejamento na aquisição de equipamentos médicos e hospitalares. Se estas estimativas do Ministério da Saúde estiverem corretas, deve-se ter aproximadamente US\$ 500 milhões/ano em equipamentos inoperantes ou sub-utilizados.

Quanto ao excesso de gastos que gera o descontrole das aquisições destes equipamentos pode-se considerar que os custos de aquisição dos equipamentos médico-hospitalares podem atingir $75 \%$ do valor da construção civil de um hospital. Estima-se que este mercado movimente no Brasil algo em torno de US\$ 1,3 bilhão/ano.

Há uma estimativa de que só para a reposição dos tubos geradores de radiação dos equipamentos de tomografia computadorizada, o sistema de saúde gaste anualmente US\$ 18 milhões. Estes valores mostram a necessidade de se ter um controle da quantidade de certos equipamentos importados e também do tipo de complexidade tecnológica que se deve adotar.

Quanto à vulnerabilidade externa, no ano 2000 foram mais de US\$ 800 milhões de importações contra quase US\$ 150 milhões de exportações (ABIMO), sendo que os hospitais públicos foram os principais compradores. Muitas destas compras foram feitas por pacotes fechados para se conseguir financiamento, o que podem ter resultado em aquisições desnecessárias de equipamentos (Ministério da Saúde, 2000).

A evasão de divisas no sistema de saúde não ocorre apenas pelas aquisições dos equipamentos mas também pela aquisição de peças e pelos gastos com mão-de-obra para manutenção. Para os equipamentos de imagem, por exemplo, as empresas cobram um valor de $4 \%$ a $6 \%$ sobre o valor do equipamento novo como contrato de manutenção, sem considerar o preço das peças de reposição. Uma publicação da Gazeta Mercantil (Panorama Setorial - Análise Setorial: Sistema Hospitalar) aponta para o fato de que no período de 1994 a 1998 foram importados aproximadamente US\$ 1.190 milhão em equipamentos de imagem. Deste modo, no ano de 1999 o setor da saúde deve ter gasto,

\footnotetext{
${ }^{16}$ O Setor Saúde e o Complexo da Saúde no Brasil. UNICAMP. Núcleo de Estudos de Políticas Públicas, 2000.
} 
somente com mão-de-obra para a manutenção destes equipamentos, um valor aproximado de US\$ 71 milhões (Ministério da Saúde, 2000).

Por estes motivos pode ser benéfico para a sociedade que haja um controle da qualidade e da quantidade das tecnologias incorporadas ao sistema de saúde, já que não é possível financiar todas as melhores tecnologias existentes. Um planejamento tecnológico pode proporcionar grandes economias de custos para o sistema de saúde ${ }^{17}$. Por causa dos elevados custos dos equipamentos médicos, vários países (como Canadá, EUA, Inglaterra, França e outros) criaram agências que auxiliam nas decisões de aquisição de novas tecnologias no setor médico ${ }^{18}$.

Neste sentido, seria importante incentivar iniciativas como o Programa de Engenharia Biomédica da Universidade Federal do Rio de Janeiro, que oferece um serviço de avaliação de tecnologia em saúde, criado a partir da percepção da necessidade de se estabelecer prioridades na alocação dos recursos em saúde devido aos custos crescentes destas tecnologias. Estes serviços dão informações baseadas em evidências científicas sobre a eficácia, a efetividade e os custos das novas tecnologias em saúde.

\footnotetext{
${ }^{17}$ No Canadá, por exemplo, foram comparadas técnicas de rastreamento do câncer cervical. Enquanto a utilização do equipamento AutoPap representava um custo de US\$ 400,00, o mesmo serviço com o equipamento PAPNET custava US\$ 810,00 . No entanto, a sensitividade do PAPNET é de $83 \%$ enquanto a sensitividade do AutoPap é de $80 \%$, ou seja, tem-se um custo muito superior pelo uso do equipamento PAPNET com um incremento muito pequeno de efetividade porque esta pequena diferença de sensitividade praticamente não altera a detecção do câncer do colo uterino.

${ }^{18} \mathrm{Na}$ França é preciso que se tenha uma autorização do governo para a compra destes equipamentos de preços elevados, para que não haja uma imobilização exagerada destes equipamentos pelo sistema de saúde.
} 


\section{Capítulo 3}

\section{A Indústria Ligada à Área da Saúde em Ribeirão Preto.}

A cidade de Ribeirão Preto é conhecida por ser um centro de excelência nos serviços de saúde, em boa parte devido ao ensino superior nesta área. $\mathrm{O}$ setor da saúde em Ribeirão Preto gerou em 1998 um total de 11.045 empregos entre empregos da indústria, comércio e serviços.

\begin{tabular}{|l|c|c|c|c|}
\hline \multicolumn{5}{|c|}{ Tabela 3.1 } \\
\hline \multicolumn{3}{|c|}{ Participação do Setor Saúde no Emprego - Ribeirão Preto 1998 } \\
\hline \hline & Indústria & Comércio & Serviços & Total \\
\hline \begin{tabular}{l}
\hline No estab. do setor da \\
saúde
\end{tabular} & 51 & 332 & 1.037 & 1.420 \\
\hline$N^{\circ}$ estab. totais & 1.065 & 5.043 & 4.783 & 10.891 \\
\hline $\begin{array}{l}N^{\circ} \text { empregados formais } \\
\text { do setor da saúde }\end{array}$ & 1.848 & 2.108 & 7.089 & 11.045 \\
\hline$N^{\circ}$ emprego formal & 14.722 & 26.493 & 57.850 & 99.065 \\
\hline
\end{tabular}

Fonte: RAIS, 1999.

Segundo dados da RAIS, a indústria do setor saúde na cidade de Ribeirão Preto, que gerou um total de 1848 empregos em 1998, pode ser dividida na fabricação de produtos farmacoquímicos $(225)^{19}$, medicamentos para uso humano (485) e veterinário (114), materiais (18), aparelhos e instrumentos (973) para uso médico, hospitalar e odontológico, instrumentos óticos (4), perfumaria e cosmético (29) entre outros. Dos 51 estabelecimentos da indústria da saúde, 31 eram estabelecimentos para a produção de aparelhos e instrumentos médicos, hospitalares e odontológicos naquele ano. $\mathrm{O}$ total do comércio atacadista e varejista no município de Ribeirão Preto somou 322 estabelecimentos gerando 2108 empregos.

A área da saúde inclui profissionais como médicos, farmacologistas, biólogos, dentistas, psicólogos, terapeutas, operadores de equipamentos médicos e odontológicos, professores, funcionários de laboratórios entre outros. O setor de serviços relacionados à saúde empregou mais de 7000 pessoas no município, sendo que $70 \%$ dos empregados eram do setor privado. Enquanto a média estadual era de 2,02 médicos para cada mil habitantes e de

19 Os números entre parênteses são o número de empregados formais por ramo industrial. 
2,77 dentistas por mil habitantes, estes coeficientes para o município de Ribeirão Preto foram de 5,84 médicos por mil habitantes e de 6 dentistas para cada mil habitantes.

A configuração da indústria médica, em que há pequenas empresas que conquistam certos nichos de mercado, convivendo com empresas maiores, é que possibilita oportunidades para a região de Ribeirão Preto na constituição de um pólo de saúde. As possibilidades de produção desta indústria são impulsionadas por haver um complexo da saúde formado por um sistema universitário, centros de pesquisa e um vasto sistema público e privado de saúde. Este sistema pode ser uma vantagem comparativa na atração de novos investimentos para o município pela proximidade que estabelece entre o desenvolvimento tecnológico, o setor produtivo e os usuários.

\section{As Empresas do Setor da Saúde em Ribeirão Preto}

Neste capítulo analisamos a indústria da saúde em Ribeirão Preto através de uma pesquisa de campo realizada com as empresas locais. Inicialmente foram contatadas 51 empresas dos setores de equipamentos, instrumentos e produtos médicos, hospitalares e odontológicos em Ribeirão Preto. Este levantamento foi realizado analisando-se os cadastros de empresas de duas entidades de apoio empresarial do município, a ACI (Associação Comercial e Industrial) e o CIESP (Centro da Indústria do Estado de São Paulo - sede regional). Posteriormente, constatou-se que das 51 empresas do setor da saúde, 31 eram fabricantes e 20 que se classificavam como indústria apenas comercializavam. Do total das 31 indústrias, 28 responderam o questionário ${ }^{20}$.

\subsection{Tamanho, capital e planta produtiva.}

As empresas da área da saúde que participaram da pesquisa são, na sua maioria, empresas de pequeno porte. A média geral do número de empregados dessas empresas está em torno de 48 funcionários, mas há uma grande dispersão no tamanho das empresas. Se não se considera as três maiores, com média de 288 funcionários, a média das 25 restantes passa a ser de 19 empregados. As três empresas maiores atuam nos setores odontológico e farmacêutico.

\footnotetext{
${ }^{20}$ Deve-se considerar que pode haver empresas ligadas à área da saúde que tenham ficado de fora da pesquisa por estarem classificadas como pertencentes a outros setores.
} 
A origem do capital de $93 \%$ das empresas da amostra é nacional. Apenas duas empresas disseram ter capital estrangeiro na sua formação, com participação de $25 \%$ do total do capital da empresa, sendo estas duas pertencentes ao mesmo grupo empresarial.

Além disso, quase a totalidade das empresas possui plantas industriais apenas no município de Ribeirão Preto. Apenas a Biosintética Ltda não possui sede localizada no município, sendo também a única a ter plantas industriais fora de Ribeirão Preto (São Paulo capital e Taboão da Serra).

\subsection{Principais produtos.}

Na tabela 3.2. estão os principais produtos da indústria da saúde em Ribeirão Preto e o número de empresas fabricantes destes produtos. Neste caso, uma empresa que produz diferentes linhas de produtos será considerada mais de uma vez. Pode-se observar uma presença maior de empresas fabricantes de produtos e equipamentos ligados à odontologia. Como será visto na tabela 3.3., de 28 empresas da amostra, 13 são deste setor.

Tabela 3.2.

\section{Principais Produtos da Indústria da Saúde em Ribeirão Preto}

\begin{tabular}{|l|c|}
\hline Setor Odontológico & $N^{\circ}$ Empresas \\
\hline Peças de mão & 6 \\
\hline Fabricação de consultórios & 3 \\
\hline Raio X odontológico & 2 \\
\hline Escovas dentais & 1 \\
\hline Microaparelhos para odontologia, ceras e pré-moldados & 1 \\
\hline Setores Médico, Hospitalar e Laboratorial & $N^{\circ}$ Empresas \\
\hline Fabricação de bisturis eletrônicos & 4 \\
\hline Doppler fetal & 4 \\
\hline Colposcópios & 3 \\
\hline Equipamentos e instrumentos neonatológicos & 2 \\
\hline Equipamentos e acessórios de Esterilização & 2 \\
\hline Fabricação de Mesas cirúrgicas & 2 \\
\hline Fabricação de Soluções Parenterais & 1 \\
\hline Fabricação de Instrumentos Cirúrgicos & 2 \\
\hline \hline
\end{tabular}


A tabela 3.3. apresenta os principais produtos por empresas da amostra e sua participação no faturamento da empresa. A fim de facilitar a exposição das tabelas, as empresas foram numeradas de 1 a 28 , em ordem de entrega dos questionários.

Como pode ser observado, há uma tendência da maioria das empresas em se especializarem em alguns produtos, ou melhor, na maioria delas pode-se selecionar um ou dois produtos que são o carro-chefe da empresa. Em conformidade com o que foi falado no capítulo anterior, a estratégia da especialização é geralmente adotada pelas pequenas empresas como meio de conseguirem sobreviver em um mercado competitivo como é o setor de equipamentos médicos e odontológicos. 


\begin{tabular}{|c|c|c|c|c|c|}
\hline \multicolumn{6}{|c|}{ Tabela 3.3.} \\
\hline \multicolumn{6}{|c|}{ Principais Linhas de Produtos e Participação no Faturamento } \\
\hline Cód. & Produtos & $\begin{array}{r}\% \text { fat. } \\
2000\end{array}$ & Cód. & Produtos & $\begin{array}{r}\% \text { fat. } \\
2000\end{array}$ \\
\hline 1 & equipamentos odontológicos & 56 & 15 & $\begin{array}{l}\text { alta e baixa rotação } \\
\text { acessórios odont. e equipos modulares }\end{array}$ & $\begin{array}{l}90 \\
10\end{array}$ \\
\hline 2 & $\begin{array}{l}\text { bisturis eletrônicos } \\
\text { acessórios p/ eletrocirurgia }\end{array}$ & $\begin{array}{l}80 \\
20\end{array}$ & 16 & $\begin{array}{l}\text { soluções parenterais de grande vol. } \\
\text { germicidas hospitalares }\end{array}$ & $\begin{array}{l}75 \\
25\end{array}$ \\
\hline 3 & $\begin{array}{l}\text { canetas de alta rotação } \\
\text { micromotores } \\
\text { contra-ângulo } \\
\text { motor elétrico } \\
\end{array}$ & $\begin{array}{l}30 \\
30 \\
15 \\
10\end{array}$ & 17 & $\begin{array}{l}\text { próteses para membros } \\
\text { órteses para membros } \\
\text { coletes corretivos } \\
\text { acessórios }\end{array}$ & $\begin{array}{c}70 \\
20 \\
5 \\
5 \\
\end{array}$ \\
\hline 4 & $\begin{array}{l}\text { equip. p/ lab. de pesq. } \\
\text { Projetos }\end{array}$ & $\begin{array}{l}80 \\
20\end{array}$ & 18 & $\begin{array}{l}\text { articulador semi ajustável } \\
\text { peças de mão (alta e baixa rotação) }\end{array}$ & $\begin{array}{l}50 \\
50\end{array}$ \\
\hline 5 & $\begin{array}{l}\text { soluções parenterais } \\
\text { bolsas de Sangue } \\
\text { descartáveis } \\
\text { outros } \\
\end{array}$ & $\begin{array}{l}55 \\
18 \\
15 \\
12 \\
\end{array}$ & 19 & $\begin{array}{l}\text { cardiotocografos } \\
\text { detectores fetais } \\
\text { bisturis elétricos } \\
\text { foco clínico }\end{array}$ & $\begin{array}{l}40 \\
30 \\
20 \\
10\end{array}$ \\
\hline 6 & $\begin{array}{l}\text { kit cirurgia arthroscopia } \\
\text { micromotor arthroscopia } \\
\text { segurador de perna }\end{array}$ & 70 & 20 & $\begin{array}{l}\text { escovas dentais específicas } \\
\text { aparelho vibrador direcional }\end{array}$ & $\begin{array}{l}80 \\
20\end{array}$ \\
\hline 7 & $\begin{array}{l}\text { colposcópio } \\
\text { mesa para exame } \\
\text { sistema de alta frequência }\end{array}$ & & 21 & $\begin{array}{l}\text { colposcópio } \\
\text { foco clínico } \\
\text { detector fetal } \\
\text { citoaspirador }\end{array}$ & $\begin{array}{l}60 \\
15 \\
15 \\
10\end{array}$ \\
\hline 8 & $\begin{array}{l}\text { detector fetal ultras. mesa } \\
\text { detector fetal ultras. digital } \\
\text { detec. fetal ultrassônico portátil } \\
\text { detector vascular portátil }\end{array}$ & $\begin{array}{c}40 \\
24 \\
23 \\
4\end{array}$ & 22 & $\begin{array}{l}\text { vídeocolposcópio } \\
\text { bisturi de alta frequência } \\
\text { aspirador de vapores orgânicos } \\
\text { criocautéreo }\end{array}$ & $\begin{array}{l}50 \\
20 \\
15 \\
15\end{array}$ \\
\hline 9 & $\begin{array}{l}\text { neonatológica } \\
\text { esterilização } \\
\text { laboratorial } \\
\text { outros }\end{array}$ & $\begin{array}{c}67 \\
12 \\
16 \\
5\end{array}$ & 23 & $\begin{array}{l}\text { incubadoras } \\
\text { berços aquecidos } \\
\text { mesas cirúrgicas } \\
\text { fototerapias }\end{array}$ & $\begin{array}{l}40 \\
30 \\
15 \\
15\end{array}$ \\
\hline 10 & aparelhos de raio $\mathrm{X}$ odontológico & 100 & 24 & consultório odontológico & 100 \\
\hline 11 & $\begin{array}{l}\text { pinça auricular } \\
\text { aparelhos cirúrgicos p/ otorrinol. }\end{array}$ & & 25 & $\begin{array}{l}\text { micromotor } \\
\text { caneta alta rotação } \\
\text { contra-ângulo } \\
\text { seringa tríplice }\end{array}$ & $\begin{array}{l}30 \\
40 \\
15 \\
15 \\
\end{array}$ \\
\hline 12 & $\begin{array}{l}\text { bisturis elétricos } \\
\text { doppler fetal }\end{array}$ & $\begin{array}{c}95 \\
5 \\
\end{array}$ & 26 & $\begin{array}{l}\text { consultório odontológico } \\
\text { peças de mão }\end{array}$ & $\begin{array}{l}50 \\
50 \\
\end{array}$ \\
\hline 13 & $\begin{array}{l}\text { alta rotação } \\
\text { baixa rotação } \\
\text { protetor facial } \\
\text { equip. fotopolimerizador / profilaxia }\end{array}$ & $\begin{array}{c}45,5 \\
32,5 \\
10 \\
12\end{array}$ & 27 & $\begin{array}{l}\text { estufas } \\
\text { seladoras de papel grau cirúrgico } \\
\text { limpadoras de ultrassom } \\
\text { autoclaves } \\
\text { esterilizadores, prod. químicos, mat. Consumo }\end{array}$ & $\begin{array}{l}50 \\
20 \\
10 \\
10 \\
10\end{array}$ \\
\hline 14 & Aparelhos de raio $\mathrm{X}$ odontológico & 100 & 28 & $\begin{array}{l}\text { microaparelhos para odontologia } \\
\text { ceras e pré-moldados } \\
\text { borrachas abrasivas e manequins }\end{array}$ & $\begin{array}{l}70 \\
16 \\
14 \\
\end{array}$ \\
\hline
\end{tabular}




\subsection{Exportação.}

Outra característica do setor no município é que são empresas altamente voltadas para o mercado interno. De 28 empresas da amostra, 11 não exportam, ou seja, 39\% das empresas não exportam. Das 17 empresas restantes, apenas 2 empresas, atuantes nos ramos de ginecologia obstetrícia e consultórios odontológicos, apresentam uma inversão em relação ao comportamento predominante, ou seja, vendem mais para o mercado externo que para o interno. Em média, 70\% do faturamento destas duas empresas vêm do mercado externo. As outras 15 empresas que também disseram exportar possuem uma média de exportação de $13,14 \%$ do faturamento.

Algumas empresas responderam exportar indiretamente, o que seria realizado pelo distribuidor, por isso não haveria controle por parte da empresa de quanto ela exporta, mesmo assim, consideraram ser uma parcela muito pequena do faturamento.

Muitas disseram não exportar por nunca terem tentado qualquer estratégia nesse sentido, demonstrando que não há uma cultura exportadora entre estas empresas. Isto pode ser observado quando questionadas sobre as dificuldades à exportação, várias não responderam a esta questão. Preparar as empresas para a exportação pode ser um caminho importante de apoio setorial e de futuro crescimento dessas empresas. 


\begin{tabular}{|c|c|c|c|c|c|c|c|}
\hline \multicolumn{8}{|c|}{ Tabela 3.4.} \\
\hline \multicolumn{8}{|c|}{ Distribuição do Faturamento entre Mercado Interno e Externo } \\
\hline Cód. & Produtos & $\begin{array}{l}\text { \% fat. } \\
\text { merc. } \\
\text { interno }\end{array}$ & $\begin{array}{l}\text { \% fat. } \\
\text { merc. } \\
\text { externo }\end{array}$ & Cód. & Produtos & $\begin{array}{l}\text { \% fat. } \\
\text { merc. } \\
\text { interno }\end{array}$ & $\begin{array}{l}\text { \% fat. } \\
\text { merc. } \\
\text { externo }\end{array}$ \\
\hline 1 & equipamentos odontológicos & 90 & 10 & 15 & $\begin{array}{l}\text { alta e baixa rotação } \\
\text { acessórios odontológicos e } \\
\text { equipos modulares }\end{array}$ & $\begin{array}{l}70 \\
95\end{array}$ & $\begin{array}{c}30 \\
5\end{array}$ \\
\hline 2 & $\begin{array}{l}\text { bisturis eletrônicos } \\
\text { acessórios p/ eletrocirurgia }\end{array}$ & 90 & 10 & 16 & $\begin{array}{l}\text { soluções parenterais de } \\
\text { grande vol. } \\
\text { germicidas hospitalares }\end{array}$ & $\begin{array}{l}100 \\
100\end{array}$ & 0 \\
\hline 3 & $\begin{array}{l}\text { canetas de alta rotação } \\
\text { micromotores } \\
\text { contra-ângulo } \\
\text { motor elétrico }\end{array}$ & 95 & 5 & 17 & $\begin{array}{l}\text { próteses } \\
\text { órteses } \\
\text { coletes } \\
\text { acessórios }\end{array}$ & $\begin{array}{l}100 \\
100 \\
100 \\
100 \\
\end{array}$ & $\begin{array}{l}0 \\
0 \\
0 \\
0\end{array}$ \\
\hline 4 & $\begin{array}{l}\text { equip. p/ lab. de pesq. } \\
\text { Projetos }\end{array}$ & 100 & 0 & 18 & $\begin{array}{l}\text { articulador semi ajustável } \\
\text { peças de mão (alta e baixa } \\
\text { rotação) }\end{array}$ & $\begin{array}{l}80 \\
80\end{array}$ & $\begin{array}{l}20 \\
20\end{array}$ \\
\hline 5 & $\begin{array}{l}\text { soluções parenterais } \\
\text { bolsas de Sangue } \\
\text { descartáveis } \\
\text { outros }\end{array}$ & 100 & 0 & 19 & $\begin{array}{l}\text { cardiotocografos } \\
\text { detectores fetais } \\
\text { bisturis elétricos } \\
\text { foco clínico }\end{array}$ & $\begin{array}{c}100 \\
93 \\
90 \\
90 \\
\end{array}$ & $\begin{array}{c}0 \\
7 \\
10 \\
10\end{array}$ \\
\hline 6 & $\begin{array}{l}\text { kit cirurgia arthroscopia } \\
\text { micromotor arthroscopia } \\
\text { segurador de perna }\end{array}$ & 100 & 0 & 20 & $\begin{array}{l}\text { escovas dentais específicas } \\
\text { aparelho vibrador direcional }\end{array}$ & $\begin{array}{l}100 \\
100\end{array}$ & $\begin{array}{l}0 \\
0\end{array}$ \\
\hline 7 & $\begin{array}{l}\text { coposcópio } \\
\text { mesa para exame } \\
\text { sistema de alta frequência }\end{array}$ & 95 & 5 & 21 & $\begin{array}{l}\text { colposcópio } \\
\text { foco clínico } \\
\text { detector fetal } \\
\text { citoaspirador } \\
\end{array}$ & $\begin{array}{l}100 \\
100 \\
100 \\
100 \\
\end{array}$ & $\begin{array}{l}0 \\
0 \\
0 \\
0\end{array}$ \\
\hline 8 & $\begin{array}{l}\text { detector fetal ultras. de mesa } \\
\text { detector fetal ultras. Digital } \\
\text { detec. fetal ultras. portátil } \\
\text { detector vascular portátil }\end{array}$ & 100 & 0 & 22 & $\begin{array}{l}\text { vídeocoposcópio } \\
\text { bisturi de alta frequência } \\
\text { aspirador de vapores } \\
\text { orgânicos } \\
\text { criocautéreo }\end{array}$ & $\begin{array}{l}30 \\
30 \\
30 \\
30\end{array}$ & $\begin{array}{l}70 \\
70 \\
70 \\
70 \\
\end{array}$ \\
\hline 9 & $\begin{array}{l}\text { neonatológica } \\
\text { esterilização } \\
\text { laboratorial } \\
\text { outros }\end{array}$ & $\begin{array}{l}95 \\
96 \\
98\end{array}$ & $\begin{array}{l}5 \\
4 \\
2\end{array}$ & 23 & $\begin{array}{l}\text { incubadoras } \\
\text { berços aquecidos } \\
\text { mesas cirúrgicas } \\
\text { fototerapias }\end{array}$ & $\begin{array}{l}80 \\
80 \\
80 \\
80 \\
\end{array}$ & $\begin{array}{l}20 \\
20 \\
20 \\
20\end{array}$ \\
\hline 10 & $\begin{array}{l}\text { aparelhos de raio } \mathrm{X} \\
\text { odontológico }\end{array}$ & 70 & 30 & 24 & consultório odontológico & 35 & 65 \\
\hline 11 & $\begin{array}{l}\text { pinça auricular } \\
\text { aparelhos cirúrgicos } \mathrm{p} / \\
\text { otorrinol. }\end{array}$ & 100 & 0 & 25 & $\begin{array}{l}\text { micromotor } \\
\text { caneta alta rotação } \\
\text { contra-ângulo } \\
\text { seringa tríplice }\end{array}$ & $\begin{array}{l}80 \\
80 \\
80 \\
80\end{array}$ & $\begin{array}{l}20 \\
20 \\
20 \\
20\end{array}$ \\
\hline 12 & $\begin{array}{l}\text { bisturis elétricos } \\
\text { doppler fetal }\end{array}$ & $\begin{array}{l}98 \\
98 \\
\end{array}$ & $\begin{array}{l}2 \\
2\end{array}$ & 26 & $\begin{array}{l}\text { consultório odontológico } \\
\text { peças de mão }\end{array}$ & $\begin{array}{l}100 \\
100 \\
\end{array}$ & $\begin{array}{l}0 \\
0\end{array}$ \\
\hline 13 & $\begin{array}{l}\text { alta rotação } \\
\text { baixa rotação } \\
\text { protetor facial } \\
\text { equip. foto / profilaxia }\end{array}$ & $\begin{array}{l}70 \\
70 \\
90 \\
70 \\
\end{array}$ & $\begin{array}{l}30 \\
30 \\
10 \\
30 \\
\end{array}$ & 27 & $\begin{array}{l}\text { estufas } \\
\text { seladoras de papel grau } \\
\text { cirúrgico } \\
\text { autoclaves }\end{array}$ & $\begin{array}{l}85 \\
90 \\
95 \\
\end{array}$ & $\begin{array}{l}15 \\
10 \\
5\end{array}$ \\
\hline 14 & $\begin{array}{l}\text { Aparelhos de raio } \mathrm{X} \\
\text { odontológico }\end{array}$ & 90 & 10 & 28 & $\begin{array}{l}\text { microaparelhos odontologia } \\
\text { ceras e pré-moldados } \\
\text { borrachas abrasivas } \\
\text { manequins }\end{array}$ & $\begin{array}{l}100 \\
100 \\
100 \\
100\end{array}$ & $\begin{array}{l}0 \\
0 \\
0 \\
0\end{array}$ \\
\hline
\end{tabular}

As empresas locais foram questionadas quanto ao destino dos seus produtos de exportação.

O comércio regional mostrou-se predominantemente mais forte que o comércio com outras 
regiões do mundo. Os principais países consumidores das mercadorias locais, em ordem decrescente de importância são os países da América Latina (83\% das empresas exportam para países como a Argentina, Paraguai, Uruguai, Peru, Chile, Bolívia e Venezuela), os países da Europa (28\%) como a Itália, Portugal, Grécia, Rússia e outros países do leste europeu e países do Oriente Médio (11\%).

Os principais demandantes e as principais formas de comercialização das exportações são os distribuidores atacadistas. Poucas possuem uma estratégia definida ou um departamento organizado para exportação. Duas empresas apenas disseram efetuar vendas diretas com o consumidor externo e apenas uma disse participar de licitações no exterior.

Entre as que exportam, as principais dificuldades de expansão do comércio no exterior são a ausência de linhas de financiamento adequadas, a falta de uma boa rede de distribuição e a legislação do setor nos outros países. Na tabela 3.5. estão os principais pontos levantados pelas empresas e o número de empresas que consideram cada item um problema para a exportação.

Para as que não exportam, os principais motivos apresentados foram: em primeiro lugar, a falta de certificação, como as certificações ISO, o segundo motivo mais apontado é a legislação muito rígida de muitos países e a presença de fortes barreiras à entrada impostas por países principalmente da Europa e os EUA. Em seguida os fatores apontados foram a falta de divulgação no exterior, a ausência de linhas de financiamento e problemas de qualidade dos insumos utilizados. 


\begin{tabular}{|l|c|}
\hline \multicolumn{1}{|c|}{ Tabela 3.5. } \\
\hline \multicolumn{1}{|c|}{ Principais Dificuldades para Entrar no Mercado Externo } & No Empresas \\
\hline Ausência de linhas de financiamento adequadas & $\mathbf{9}$ \\
\hline Rede de distribuição & 7 \\
\hline Legislação / regulamentações no setor & $\mathbf{6}$ \\
\hline Marketing & $\mathbf{6}$ \\
\hline Rede de assistência técnica & $\mathbf{6}$ \\
\hline Defasagem tecnológica & 5 \\
\hline Qualidade do produto oferecido & $\mathbf{5}$ \\
\hline Certificações internacionais e certificações ISO & 4 \\
\hline Custo de produção & $\mathbf{4}$ \\
\hline \hline Barreiras aduaneiras & $\mathbf{1}$ \\
\hline \hline Cultura dos usuários & \\
\hline \hline "Pacotes integrados dos concorrentes" (venda/financiamento/assistência, \\
etc.)
\end{tabular}

\subsection{Setor privado $\mathrm{x}$ público.}

No mercado interno o setor privado absorve quase que totalmente a produção dessas empresas. Em média, $75 \%$ do faturamento destas empresas vêm do setor privado. Do total de empresas da amostra, 7 fornecem exclusivamente para o setor privado, são elas fabricantes de aparelhos e equipamentos de artroscopia, ginecologia obstetrícia, esterilização e odontologia.

A predominância do setor privado pode ser explicada em parte pelos segmentos de atuação da indústria em Ribeirão Preto, como é o caso do setor odontológico.

Cinco empresas apresentam faturamento equilibrado entre setor público e privado. Estas atuam nos segmentos de equipamentos para laboratórios de pesquisa ( 1 empresa), bisturis elétricos e detectores fetais (1), soluções parenterais (1), próteses para membros (1) e escovas dentais específicas (1).

Outras 5 empresas apresentaram um padrão de faturamento em que o setor público é mais importante que o privado. São empresas produtoras de bisturis eletrônicos, soluções parenterais, detectores fetais, equipamentos e peças neonatológicas (incubadoras, berços aquecidos etc.). 


\begin{tabular}{|c|c|c|c|c|c|c|c|}
\hline \multicolumn{8}{|c|}{ Tabela 3.6.} \\
\hline \multicolumn{8}{|c|}{ Distribuição do Faturamento entre Setor Público e Privado } \\
\hline Cód. & Produtos & $\begin{array}{l}\text { \% fat. } \\
\text { setor } \\
\text { público }\end{array}$ & $\begin{array}{c}\% \text { fat. } \\
\text { setor } \\
\text { privado }\end{array}$ & Cód. & Produtos & $\begin{array}{l}\text { \% fat. } \\
\text { setor } \\
\text { público }\end{array}$ & $\begin{array}{l}\% \text { fat. setor } \\
\text { privado }\end{array}$ \\
\hline 1 & Equipamentos odontológicos & 3.5 & 96.5 & 15 & $\begin{array}{l}\text { alta e baixa rotação } \\
\text { acessórios odontológicos e } \\
\text { equipos modulares }\end{array}$ & $\begin{array}{l}5 \\
5\end{array}$ & $\begin{array}{l}95 \\
95\end{array}$ \\
\hline 2 & $\begin{array}{l}\text { bisturis eletrônicos } \\
\text { acessórios p/ eletrocirurgia }\end{array}$ & $\begin{array}{l}70 \\
60\end{array}$ & $\begin{array}{l}30 \\
40\end{array}$ & 16 & $\begin{array}{l}\text { soluções parenterais de } \\
\text { grande vol. } \\
\text { germicidas hospitalares }\end{array}$ & $\begin{array}{l}55 \\
20\end{array}$ & $\begin{array}{l}45 \\
80 \\
\end{array}$ \\
\hline 3 & $\begin{array}{l}\text { canetas de alta rotação } \\
\text { micromotores } \\
\text { contra-ângulo } \\
\text { motor elétrico }\end{array}$ & 30 & 70 & 17 & $\begin{array}{l}\text { próteses para membros } \\
\text { órteses para membros } \\
\text { coletes corretivos } \\
\text { acessórios }\end{array}$ & $\begin{array}{l}70 \\
60 \\
50 \\
10 \\
\end{array}$ & $\begin{array}{l}30 \\
40 \\
50 \\
90 \\
\end{array}$ \\
\hline 4 & $\begin{array}{l}\text { equip. p/ lab. de pesq. } \\
\text { Projetos }\end{array}$ & 50 & 50 & 18 & $\begin{array}{l}\text { articulador semi ajustável } \\
\text { peças de mão (alta e baixa } \\
\text { rotação) }\end{array}$ & $\begin{array}{l}25 \\
25\end{array}$ & $\begin{array}{l}75 \\
75\end{array}$ \\
\hline 5 & $\begin{array}{l}\text { soluções parenterais } \\
\text { bolsas de Sangue } \\
\text { descartáveis } \\
\text { outros }\end{array}$ & $\begin{array}{c}60 \\
75 \\
50 \\
0\end{array}$ & $\begin{array}{c}40 \\
25 \\
50 \\
0\end{array}$ & 19 & $\begin{array}{l}\text { cardiotocografos } \\
\text { detectores fetais } \\
\text { bisturis elétricos } \\
\text { foco clínico }\end{array}$ & $\begin{array}{l}0 \\
0 \\
0 \\
0\end{array}$ & $\begin{array}{l}100 \\
100 \\
100 \\
100\end{array}$ \\
\hline 6 & $\begin{array}{l}\text { kit cirurgia arthroscopia } \\
\text { micromotor arthroscopia } \\
\text { segurador de perna }\end{array}$ & 0 & 100 & 20 & $\begin{array}{l}\text { escovas dentais específicas } \\
\text { aparelho vibrador direcional }\end{array}$ & $\begin{array}{c}40 \\
0\end{array}$ & $\begin{array}{c}60 \\
100\end{array}$ \\
\hline 7 & $\begin{array}{l}\text { coposcópio } \\
\text { mesa para exame } \\
\text { sistema de alta frequência }\end{array}$ & 10 & 90 & 21 & $\begin{array}{l}\text { colposcópio } \\
\text { foco clínico } \\
\text { detector fetal } \\
\text { citoaspirador }\end{array}$ & $\begin{array}{l}5 \\
5 \\
5 \\
5\end{array}$ & $\begin{array}{l}95 \\
95 \\
95 \\
95\end{array}$ \\
\hline 8 & $\begin{array}{l}\text { detector fetal ultras. de mesa } \\
\text { detector fetal ultras. Digital } \\
\text { detec. fetal ultras. portátil } \\
\text { detector vascular portátil }\end{array}$ & 85 & 15 & 22 & $\begin{array}{l}\text { vídeocoposcópio } \\
\text { bisturi de alta frequência } \\
\text { aspirador de vapores } \\
\text { orgânicos } \\
\text { criocautéreo }\end{array}$ & $\begin{array}{l}0 \\
0 \\
0 \\
0\end{array}$ & $\begin{array}{l}100 \\
100 \\
100 \\
100\end{array}$ \\
\hline 9 & $\begin{array}{l}\text { neonatológica } \\
\text { esterilização } \\
\text { laboratorial } \\
\text { outros }\end{array}$ & $\begin{array}{l}65 \\
20 \\
25\end{array}$ & $\begin{array}{l}35 \\
80 \\
75\end{array}$ & 23 & $\begin{array}{l}\text { incubadoras } \\
\text { berços aquecidos } \\
\text { mesas cirúrgicas } \\
\text { fototerapias }\end{array}$ & $\begin{array}{l}70 \\
70 \\
70 \\
70 \\
\end{array}$ & $\begin{array}{l}30 \\
30 \\
30 \\
30 \\
\end{array}$ \\
\hline 10 & $\begin{array}{l}\text { aparelhos de raio } \mathrm{X} \\
\text { odontológico }\end{array}$ & 5 & 95 & 24 & consultório odontológico & 10 & 90 \\
\hline 11 & $\begin{array}{l}\text { pinça auricular } \\
\text { aparelhos cirúrgicos p/ } \\
\text { otorrinol. }\end{array}$ & 10 & 90 & 25 & $\begin{array}{l}\text { micromotor } \\
\text { caneta alta rotação } \\
\text { contra-ângulo } \\
\text { seringa tríplice }\end{array}$ & $\begin{array}{l}15 \\
15 \\
15 \\
15\end{array}$ & $\begin{array}{l}85 \\
85 \\
85 \\
85\end{array}$ \\
\hline 12 & $\begin{array}{l}\text { bisturis elétricos } \\
\text { doppler fetal }\end{array}$ & $\begin{array}{l}50 \\
50 \\
\end{array}$ & $\begin{array}{l}50 \\
50\end{array}$ & 26 & $\begin{array}{l}\text { consultório odontológico } \\
\text { peças de mão }\end{array}$ & $\begin{array}{l}0 \\
0\end{array}$ & $\begin{array}{l}100 \\
100 \\
\end{array}$ \\
\hline 13 & $\begin{array}{l}\text { alta rotação } \\
\text { baixa rotação } \\
\text { protetor facial } \\
\text { equip. foto / profilaxia }\end{array}$ & $\begin{array}{l}20 \\
20 \\
10 \\
20\end{array}$ & $\begin{array}{l}80 \\
80 \\
90 \\
80\end{array}$ & 27 & $\begin{array}{l}\text { estufas } \\
\text { seladoras de papel grau } \\
\text { cirúrgico } \\
\text { limpadoras de ultrassom } \\
\text { autoclaves } \\
\text { esterilizadores, prod. } \\
\text { químicos, mat. Consumo }\end{array}$ & $\begin{array}{l}0 \\
0 \\
0 \\
0 \\
0\end{array}$ & $\begin{array}{l}100 \\
100 \\
100 \\
100 \\
100\end{array}$ \\
\hline 14 & $\begin{array}{l}\text { Aparelhos de raio } \mathrm{X} \\
\text { odontológico }\end{array}$ & 0 & 100 & 28 & $\begin{array}{l}\text { microaparelhos odontologia } \\
\text { ceras e pré-moldados } \\
\text { borrachas abrasivas e } \\
\text { manequins }\end{array}$ & $\begin{array}{l}0 \\
0 \\
0 \\
0 \\
\end{array}$ & $\begin{array}{l}100 \\
100 \\
100 \\
100 \\
\end{array}$ \\
\hline
\end{tabular}

A falta de clientes do setor público pode ser explicada por alguns fatores a seguir: 
- pelo tamanho das empresas. Por serem empresas pequenas, estas apresentam dificuldades em atender a grandes pedidos em espaços de tempo reduzido, como pode ser o caso das licitações públicas.

- por não terem um acompanhamento sistemático das aberturas de licitações públicas, ao contrário do que ocorre nas empresas maiores que muitas vezes possuem funcionários dedicados a este tipo de atividade.

- pelo tipo de compra governamental, muitas vezes feita em pacotes em que estas empresas não conseguiriam participar devido ao fato da maioria delas serem especializadas em alguns poucos produtos.

- e finalmente, pelo fato de várias das pequenas empresas não possuírem o registro de seus produtos no Ministério da Saúde, devido aos elevados custos do processo de obtenção deste certificado, impossibilitando que participem das compras públicas.

\subsection{Principais demandantes.}

Foi pedido às empresas que especificassem os principais tipos de demandantes, 22 das 28 empresas da indústria responderam à pergunta.

Constatou-se que $82 \%$ das empresas usam os distribuidores atacadistas para atingir o mercado, $50 \%$ destas empresas disseram vender diretamente para as clínicas e consultórios (aqui incluímos também as dentais e a venda para creches e escolas municipais) e 27\% também vendem diretamente para hospitais, tanto públicos como privados e filantrópicos.

Apenas as maiores disseram ter representantes próprios, enquanto várias empresas pequenas utilizam-se de representantes autônomos que trabalham com várias marcas.

No setor odontológico, $90 \%$ das empresas comercializam através dos distribuidores atacadistas $(90 \%)$ e apenas $60 \%$ das empresas também vendem diretamente para o consumidor final.

$\mathrm{Na}$ tabela 3.7. estão relacionados os principais demandantes e a porcentagem de empresas que utilizam estes meios para atingir o mercado. Por exemplo, $77 \%$ das empresas de equipamentos médicos utilizam-se dos distribuidores atacadistas para atingir o mercado enquanto apenas $31 \%$ das empresas deste setor disseram também comercializar diretamente com o consumidor final. 


\begin{tabular}{|l|c|c|c|}
\hline \multicolumn{4}{|c|}{ Tabela 3.7. } \\
\hline \multicolumn{3}{|c|}{ Principais Demandantes do Setor } \\
\hline & Odontologia & Medicina & Geral \\
\hline Distribuidores atacadistas & $90 \%$ & $77 \%$ & $82 \%$ \\
\hline Venda direta ao consumidor & $60 \%$ & $31 \%$ & $50 \%$ \\
\hline Hospitais & - & $46 \%$ & $27 \%$ \\
\hline
\end{tabular}

\subsection{Fornecedores e insumos.}

A rede de fornecimento das empresas locais está fortemente concentrada no Estado de São Paulo, principalmente na capital. Somente 7 empresas disseram ter fornecedores em outros estados, principalmente no Rio de Janeiro, Minas Gerais, BA e RS.

Dezoito empresas disseram possuir fornecedores da região de Ribeirão Preto, mas afirmaram não representarem a sua principal fonte de insumos. As empresas disseram que os fornecedores regionais são ainda pouco competitivos em termos de preço, qualidade e prazo de entrega do produto.

No entanto, todas acreditam que há um grande potencial de absorção de novos fornecedores, principalmente devido ao grande número de pequenas e médias empresas ligadas às áreas médico-odontológicas. Um fabricante de produtos neonatológicos considera que o processo de terceirização que vem ocorrendo pode fazer com que surjam novas empresas fornecedoras de peças. Outra firma, produtora de soluções parenterais, indicou a possibilidade das usinas de açúcar da região fabricarem glicose, já que existe um único fabricante nacional no Rio de Janeiro.

\begin{tabular}{|l|c|}
\hline \multicolumn{2}{|c|}{ Tabela 3.8. } \\
\hline \multicolumn{2}{|c|}{ Localização dos Principais Fornecedores } \\
\hline Região de Ribeirão Preto & 18 \\
\hline Outras regiões do Estado de São Paulo & 27 \\
\hline Outros Estados & 7 \\
\hline
\end{tabular}


A importação de insumos não parece ter um peso muito grande no gasto total de insumos, a não ser quando se fala de componentes eletrônicos, que são todos importados, principalmente dos EUA. Seis empresas utilizam apenas insumos nacionais.

A participação dos insumos importados no custo de produção é mais elevada para as empresas fabricantes de: germicidas hospitalares $(75 \%$ dos gastos com insumos referem-se a insumos importados), silicone para manequins bucais, fabricação de bolsas de soluções parenterais de grande volume (60\%), detectores fetais (46\%) e os tubos para aparelhos de raio $\mathrm{X}(35 \%)$.

As empresas de equipamentos odontológicos disseram utilizar quase unicamente os insumos nacionais, com exceção da importação de rolamento para a fabricação das peças de mão. Estes rolamentos podem significar de 10\% a 30\% dos custos totais com insumos.

Os principais fornecedores dos insumos importados são a Europa (13 empresas disseram importar produtos destes países), os EUA (11empresas), o Japão (8) e outros países da Ásia (5). Apenas uma empresa importa da América Latina. As peças importadas são adquiridas principalmente através de importadoras nacionais, ou seja, quase não há compras diretas com o exterior. 


\begin{tabular}{|c|c|c|c|c|c|}
\hline \multicolumn{6}{|c|}{ Tabela 3.9.} \\
\hline \multicolumn{6}{|c|}{ Participação dos Insumos Importados no Gasto Total com Insumos } \\
\hline Cód. & Produtos & $\begin{array}{l}\text { (\%) dos insumos } \\
\text { importados }\end{array}$ & Cód. & Produtos & $\begin{array}{l}\text { (\%) dos insumos } \\
\text { importados }\end{array}$ \\
\hline 1 & Equipamentos odontológicos & 10 & 15 & $\begin{array}{l}\text { alta / baixa rotação } \\
\text { acessórios odont. e equipos } \\
\text { modulares }\end{array}$ & 22 \\
\hline 2 & $\begin{array}{l}\text { bisturis eletrônicos } \\
\text { acessórios p/ eletrocirurgia }\end{array}$ & n.r. & 16 & $\begin{array}{l}\text { sol. parenterais grde vol. } \\
\text { sol. parenterais (bolsas) } \\
\text { germicidas hospitalares }\end{array}$ & $\begin{array}{c}0 \\
60 \\
75\end{array}$ \\
\hline 3 & $\begin{array}{l}\text { canetas de alta rotação } \\
\text { micromotores } \\
\text { contra-ângulo/ motor elétrico }\end{array}$ & 30 & 17 & componentes de próteses & 90 \\
\hline 4 & $\begin{array}{l}\text { equip. } \mathrm{p} / \text { lab. de pesq. } \\
\text { Projetos }\end{array}$ & 0 & 18 & $\begin{array}{l}\text { rolamento } \\
\text { articulador }\end{array}$ & $\begin{array}{c}35 \\
0\end{array}$ \\
\hline 5 & $\begin{array}{l}\text { soluções parenterais } \\
\text { bolsas de Sangue } \\
\text { descartáveis }\end{array}$ & $\begin{array}{c}3 \\
17 \\
25\end{array}$ & 19 & $\begin{array}{l}\text { cardiotocografo } \\
\text { detector fetal } \\
\text { bisturi elétrico, fococlínico }\end{array}$ & $\begin{array}{l}0 \\
0 \\
0\end{array}$ \\
\hline 6 & $\begin{array}{l}\text { kit cirurgia arthroscopia } \\
\text { micromotor arthroscopia } \\
\text { segurador de perna }\end{array}$ & 30 & 20 & $\begin{array}{l}\text { escovas dentais } \\
\text { aparelho vibrador direcional }\end{array}$ & 0 \\
\hline 7 & $\begin{array}{l}\text { coposcópio } \\
\text { mesa para exame } \\
\text { sistema de alta frequência }\end{array}$ & n.r. & 21 & $\begin{array}{l}\text { Colposcópio, foco clínico, } \\
\text { detector fetal, citoaspirador }\end{array}$ & 15 \\
\hline 8 & $\begin{array}{l}\text { detector fetal ultras. mesa } \\
\text { detector fetal ultras. digital } \\
\text { detec. fetal ultras. portátil } \\
\text { detector vascular portátil }\end{array}$ & $\begin{array}{l}22 \\
14 \\
46 \\
22\end{array}$ & 22 & sistema de vídeo & 30 \\
\hline 9 & $\begin{array}{l}\text { Neonatológica esterilização/ } \\
\text { laboratorial }\end{array}$ & 0 & 23 & monitorização & 50 \\
\hline 10 & aparelhos de raio $\mathrm{X}$ odontológico & 35 & 24 & motoredutor & 15 \\
\hline 11 & $\begin{array}{l}\text { pinça auricular } \\
\text { aparelhos cirúrgicos p/ otorrinol. }\end{array}$ & 0 & 25 & rolamento & 50 \\
\hline 12 & $\begin{array}{l}\text { bisturis elétricos } \\
\text { doppler fetal }\end{array}$ & n.r. & 26 & $\begin{array}{l}\text { motoredutor } \\
\text { rolamento }\end{array}$ & $\begin{array}{l}10 \\
20\end{array}$ \\
\hline 13 & $\begin{array}{l}\text { alta e baixa rotação } \\
\text { protetor facial } \\
\text { equip. foto / profilaxia }\end{array}$ & 0 & 27 & $\begin{array}{l}\text { limpadoras de ultrassom } \\
\text { esterilizadores de ar e água } \\
\text { autoclaves }\end{array}$ & $\begin{array}{l}12 \\
20 \\
5\end{array}$ \\
\hline 14 & $\begin{array}{l}\text { Aparelhos de raio } \mathrm{X} \\
\text { odontológico }\end{array}$ & 40 & 28 & $\begin{array}{l}\text { manequim } \\
\text { outros }\end{array}$ & $\begin{array}{l}80 \\
25\end{array}$ \\
\hline
\end{tabular}

\subsection{Principais concorrentes.}

A estrutura concorrencial das empresas locais pode ser caracterizada da seguinte forma: $75 \%$ das empresas locais disseram estar entre seus concorrentes as empresas maiores, $57 \%$ disseram ser importante a concorrência de empresas de pequeno porte e $21 \%$ disseram que também há concorrência de empresas estrangeiras.

Apesar da concorrência das empresas maiores, as empresas locais disseram que parte importante da concorrência vem de uma grande quantidade de pequenas empresas 
localizadas principalmente no próprio município. Este fato caracteriza a forte concentração da produção setorial no município. Esta característica é mais forte para as empresas de equipamentos e instrumentos odontológicos.

Na tabela 3.10. estão os principais tipos de concorrentes e o número de empresas locais que respondeu ser importante cada tipo de concorrência. Deve-se ressaltar que as empresas puderam assinalar mais de um item.

\begin{tabular}{|l|c|c|}
\hline \multicolumn{2}{|c|}{ Tabela 3.10 } \\
\hline \multicolumn{2}{|c|}{ Principais Concorrentes } \\
\hline & $N^{\circ}$ Empresas & $\%$ \\
\hline Empresas nacionais de grande porte & 21 & 75 \\
\hline Empresas nacionais de pequeno porte & 16 & 57 \\
\hline Empresas estrangeiras de grande porte & 6 & 21 \\
\hline Empresas estrangeiras de pequeno porte & 6 & 21 \\
\hline
\end{tabular}

Principalmente no setor odontológico, pode-se observar um padrão de concorrência caracterizado por, de um lado, poucas empresas de grande porte, nacionais e estrangeiras, concorrendo por produtos mais sofisticados e produtoras de consultórios completos. Por outro lado, há várias empresas nacionais de pequeno e médio porte, especializadas em alguns produtos, que competem entre si por um mercado de produtos mais simplificados. Neste caso, como apresentado nas discussões do capítulo anterior, os produtos simplificados não necessariamente são de qualidade inferior, mas buscam atender a um mercado mais barato, satisfazendo apenas às necessidades principais do produto.

Na tabela 3.11. estão a localização dos principais concorrentes e o número de empresas que assinalou cada item. Novamente, as empresas puderam marcar mais de um item. 


\begin{tabular}{|c|c|}
\hline \multicolumn{2}{|l|}{ Tabela 3.11.} \\
\hline Localização dos Principais Concorrentes & $N^{\circ}$ Empresas \\
\hline Região de Ribeirão Preto & 20 \\
\hline Outras regiões do Estado de São Paulo & 13 \\
\hline Outros Estados & 11 \\
\hline
\end{tabular}

Todas as empresas do setor odontológico apontaram a empresa Kawo, situada em Santa Catarina, como a principal concorrente estrangeira. O setor odontológico possui apenas este concorrente forte fora do Estado de São Paulo. O setor médico como um todo possui concorrentes em outros Estados, em ordem decrescente de importância, no Rio de Janeiro, no Paraná, Goiás e Ceará.

Somente uma empresa da amostra, fabricante de produtos para laboratório de pesquisa disse não ter concorrência nacional, concorrendo com empresas estrangeiras de pequeno porte. Outra empresa, fabricante de instrumentos cirúrgicos, disse ter apenas uma concorrente nacional, além da concorrência dos produtos importados.

A competição dos importados não parece ser algo que preocupa o setor. Além disso, a participação dos produtos importados varia muito para cada setor. Em média, 17\% do mercado seria suprido pelos produtos importados. Este valor foi obtido através da percepção dos empresários locais da concorrência que cada um enfrenta em seu segmento. Entretanto, vários disseram não ter certeza destes valores.

A média da concorrência dos importados no setor de equipamentos odontológicos seria de 14\%. Mas há grande diferença entre cada segmento deste setor. Enquanto a fabricação de peças de mão e consultórios teria em torno de 5\% do mercado suprido pelos importados, no mercado de microaparelhos odontológicos $90 \%$ do mercado são dos produtos importados.

No setor de equipamentos médicos, a média do mercado de importados seria de $20 \%$. Os setores com maior participação dos importados foram a produção de bolsas de sangue (45\% do mercado), os bisturis eletrônicos (40\%) e a fabricação de cardiotocografos (40\%).

Três empresas apontaram a tecnologia como a principal vantagem do produto importado sobre o nacional, foram estas uma empresa produtora de detectores fetais, uma produtora de bisturis eletrônicos e uma de equipamentos neonatológicos. Uma empresa de 
equipamentos para laboratórios de pesquisa indicou a existência de uma boa rede de fornecedores como principal vantagem dos importados, esta empresa já havia se queixado da escassez de bons fornecedores como empecilho para a exportação. A grande maioria das empresas afirma que a qualidade do produto nacional é equiparável ao importado, além do preço do produto nacional ser muito mais barato.

Finalmente, somente 3 empresas disseram dar assistência técnica para produtos importados, a maioria só oferece estes serviços para seus próprios produtos. Em alguns casos, esta é uma política adotada para garantir a fidelidade do cliente. Somente uma empresa disse representar firmas estrangeiras, que são duas firmas norte-americanas de equipamentos de teste e calibração de aparelhos eletromédicos.

\subsection{Competitividade.}

As empresas foram questionadas quanto às suas principais dificuldades para atuar no mercado interno. Os resultados e o número de empresas que assinalaram cada item são apresentados na tabela 3.12 .

\begin{tabular}{|l|c|}
\hline \multicolumn{1}{|c|}{ Tabela 3.12. } \\
\hline \multicolumn{1}{|c|}{ Principais Dificuldades de Atuação no Mercado } & No Empresas \\
\hline Ausência de linhas de financiamento adequadas & 16 \\
\hline \hline "Guerra fiscal" & 9 \\
\hline Custo de produção & 9 \\
\hline Forma das licitações & 7 \\
\hline Rede de distribuição & 6 \\
\hline Defasagem tecnológica & 6 \\
\hline Cultura dos usuários & 5 \\
\hline Marketing & 4 \\
\hline Legislação/regulamentações no setor (sanitária, médica, ambiental, etc) \\
\hline Rede de assistência técnica & 4 \\
\hline \hline $\begin{array}{l}\text { "Pacotes integrados dos concorrentes" (venda/financiamento/assistência, } \\
\text { etc.) }\end{array}$ & 3 \\
\hline Facilidades para importados & 1 \\
\hline \hline Qualidade do produto oferecido & \\
\hline
\end{tabular}

As principais queixas contra a legislação são uma legislação sanitária muito burocrática, o excesso de regulamentação e as altas taxas tributárias. Além disso, as empresas 
reclamaram da falta de organização e de assistência da vigilância sanitária e a demora para a concessão dos alvarás. Algumas empresas reclamaram da falta de físcalização da secretaria de vigilância sanitária do município, causando um diferencial competitivo para as empresas que não cumprem a legislação atual.

As empresas apontaram a falta do registro no ministério da saúde, item que não consta na tabela acima, como uma grande dificuldade para a expansão do mercado. As dificuldades de obtenção deste registro pelas pequenas empresas são, segundo as próprias empresas, a demora da vigilância sanitária municipal na concessão do alvará e a falta de conhecimento dos procedimentos para a obtenção do registro no Ministério da Saúde. Por causa da falta de informações, há uma percepção errada, principalmente entre as empresas menores, que os custos para a obtenção do registro são excessivamente elevados. Isto ocorre porque estas empresas geralmente buscam empresas especializadas na obtenção destes registros, o que pode encarecer de 5 a 10 vezes o custo do processo, impossibilitando que muitas tenham o registro.

Neste caso, uma iniciativa pública que pudesse esclarecer estes procedimentos aos empresários, e que fizesse a aproximação destes com o Ministério da Saúde, poderia baratear significativamente este processo e incentivar a regularização das empresas locais.

Quanto aos problemas internos enfrentados pelas empresas, mais da metade das firmas (57\%) disseram enfrentar problemas de qualidade de mão-de-obra, 11 empresas disseram enfrentar problemas de gestão financeira e 8 disseram ter problemas em atualização tecnológica. Mas o principal desafio das empresas menores ainda é a obtenção do registro dos seus produtos no Ministério da Saúde.

\begin{tabular}{|l|c|}
\hline \multicolumn{2}{|c|}{ Tabela 3.13. } \\
\hline \multicolumn{1}{|c|}{ Principais Desafios Internos da Empresa } & $N^{\circ}$ Empresas \\
\hline Mão-de-obra & 16 \\
\hline Gestão & 11 \\
\hline Tecnologia & 8 \\
\hline Marketing & 7 \\
\hline Outros & 9 \\
\hline
\end{tabular}

Foi pedido também que as empresas especificassem o tipo de qualificação da mão-de-obra e o número de funcionários envolvidos em P\&D. Pouco mais da metade das empresas 
possuem pelo menos 1 funcionário com superior completo, o que pode estar incluindo o próprio dono da empresa.

\begin{tabular}{|l|c|}
\hline \multicolumn{1}{|c|}{ Qualificação da Mão-de-obra } \\
\hline \multicolumn{1}{|c|}{ Qu.14. } & $N^{\circ}$ de Empresas \\
\hline Funcionários com superior completo & 16 \\
\hline Funcionários envolvidos com P\&D & 13 \\
\hline $\begin{array}{l}\text { Funcionários com pós-graduação (mestrado e } \\
\text { doutorado) }\end{array}$ & 7 \\
\hline Funcionários com cursos de especialização (MBA) & 7 \\
\hline
\end{tabular}

\subsection{Investimentos.}

$\mathrm{Na}$ tabela 3.15. estão os investimentos regulares que as empresas disseram realizar e o número de empresas da amostra que realizam tais investimentos. $\mathrm{O}$ desenvolvimento de novos produtos como principal investimento ocorre principalmente através de inovações periféricas de produtos, muitas vezes mudando-se apenas o design. No entanto, há algumas firmas que são mais inovadoras, na criação de produtos mais avançados tecnologicamente e na adaptação de tecnologia importada.

\begin{tabular}{|l|c|}
\hline \multicolumn{1}{|c|}{ Tabela 3.15. } \\
\hline \multicolumn{1}{|c|}{ Principais Investimentos Regulares } & Número de Empresas \\
\hline Desenvolvimento de novos produtos & 22 \\
\hline Controle de qualidade & 21 \\
\hline Abertura de novos mercados (feiras, missões etc) & 19 \\
\hline Modernização produtiva (novos equipamentos) & 18 \\
\hline Qualificação dos funcionários & 17 \\
\hline Marketing & 17 \\
\hline Novas técnicas de gestão & 14 \\
\hline Outros & 6 \\
\hline
\end{tabular}

Na tabela 3.16. são apresentados os tipos de experiências tecnológicas que as empresas possuem. Nota-se que há uma utilização muito pequena do potencial de pesquisa existente nos laboratórios das faculdades locais. Somente 13 empresas disseram ter tido alguma experiência neste sentido. Estas 13 possuem apenas um relacionamento informal com a 
universidade, através de conversas e sugestões dos professores. As outras 15 empresas não têm nenhuma experiência com a universidade, apesar de considerarem poder ser algo positivo para a empresa. As principais queixas dos empresários quanto às parcerias com a universidade são a falta de interesse destes órgãos, a falta de constância nos acordos e a falta de cumprimento dos prazos.

A maioria das empresas locais do setor também nunca utilizou recursos para financiamento de desenvolvimento tecnológico.

\begin{tabular}{|c|c|}
\hline \multicolumn{2}{|l|}{ Tabela 3.16.} \\
\hline Experiências em Áreas Tecnológicas & $N^{\circ}$ de Empresas \\
\hline Desenvolvimento de novos produtos & 21 \\
\hline Desenvolvimento de processos & 16 \\
\hline $\begin{array}{l}\text { Parcerias com universidades e centros de pesquisa (pesquisa, uso } \\
\text { de laboratórios, consultoria, treinamento, etc.) }\end{array}$ & 13 \\
\hline Adaptação tecnológica & 11 \\
\hline Licenciamento de tecnologia & 3 \\
\hline $\begin{array}{l}\text { Utilização de recursos de financiamento tecnológico (FINEP, } \\
\text { FAPESP, outros) }\end{array}$ & 3 \\
\hline
\end{tabular}

Existe uma grande dificuldade na constância dos investimentos em P\&D, neste caso, devese considerar que estamos tratando de pequenas empresas. A maioria disse não haver constância nos investimentos em P\&D. Na tabela 3.17. estão as respostas das empresas. As empresas que responderam à questão investem em média quase $7 \%$ do faturamento anual em P\&D. No entanto, deve-se ressaltar que a maioria das empresas não têm controle destes gastos e disseram um valor aproximado. 


\begin{tabular}{|c|c|c|c|}
\hline \multicolumn{4}{|c|}{ Tabela 3.17.} \\
\hline \multicolumn{4}{|c|}{ Percentual Médio do Faturamento Investido em P\&D no Último Triênio } \\
\hline Cód. & & Cód. & \\
\hline 1 & $2 \%$ & 15 & $2 \%$ \\
\hline 2 & $\mathrm{nr}$ & 16 & $12 \%$ \\
\hline 3 & $\mathrm{nr}$ & 17 & $\mathrm{nr}$ \\
\hline 4 & $0,5 \%$ & 18 & $10 \%$ \\
\hline 5 & U\$ 3 milhões & 19 & $10 \%$ \\
\hline 6 & $\mathrm{nr}$ & 20 & $25 \%$ \\
\hline 7 & $5 \%$ & 21 & $\mathrm{nr}$ \\
\hline 8 & $5 \%$ & 22 & $\mathrm{nr}$ \\
\hline 9 & U\$ 500.000,00 & 23 & $15 \%$ \\
\hline 10 & $\mathrm{nr}$ & 24 & $4 \%$ \\
\hline 11 & $\mathrm{nr}$ & 25 & 0 \\
\hline 12 & $10 \%$ & 26 & $1 \%$ \\
\hline 13 & $\mathrm{nr}$ & 27 & $3 \%$ \\
\hline 14 & $2 \%$ & 28 & $5 \%$ \\
\hline
\end{tabular}

n.r.: não respondido.

Apesar das dificuldades relacionadas a $\mathrm{P} \& D$, as empresas se esforçam na busca de certificação do seu produto. Entretanto, 9 das 28 empresas não possuem o registro no Ministério da Saúde. Há 16 empresas com registro no Ministério da Saúde e 3 possuem outro tipo de registro, específico às suas áreas de atuação. As principais certificações que as empresas possuem são: ISO 9000 (4 empresas), ISO 9002 (3 empresas), ISO 9001 (1 empresa), ISO 14000 (1), INMETRO (1) e IEC (2).

Neste capítulo foram abordadas várias características das empresas locais assim como as diversas dificuldades enfrentadas por estas empresas. Muitas das dificuldades de desenvolvimento da maioria das empresas locais são características de empresas de pequeno porte. Isto pode ser visto, por exemplo, quanto ao fraco desempenho das exportações e quanto às dificuldades de investimentos regulares em pesquisa. Além disso, outro impedimento para a expansão do mercado de várias empresas locais tem sido a falta do registro dos produtos no Ministério da Saúde. Tudo isto, reafirma a necessidade de organização do setor produtivo para a superação destes limites. 


\section{Capítulo 4}

\section{O Arranjo Produtivo Local.}

Este capítulo segue duas frentes de análise: uma pesquisa feita junto às empresas de equipamentos médicos, hospitalares e odontológicos e outra feita com os laboratórios e centros de pesquisa das faculdades ligadas à área da saúde. A pesquisa com as empresas foi realizada de forma mista, utilizando-se de questionários e entrevistas com os responsáveis das empresas. A pesquisa junto aos laboratórios foi feita unicamente através de questionários, apesar de ter havido conversas informais com alguns dos responsáveis destes centros, o que favoreceu a percepção de seus interesses em participarem de ações que favoreçam as relações entre os agentes do arranjo produtivo local.

O objetivo geral deste capítulo é avaliar o grau de complexidade das relações entre os agentes deste sistema produtivo local, quais sejam, as empresas, as instituições de apoio ao empresariado, os centros de pesquisa na universidade, produtores de conhecimento científico, o setor público entre outros. Ao final deste levantamento, espera-se ter uma visão mais clara do que poderia ser caracterizado um cluster da saúde neste município.

\subsection{As empresas.}

\subsubsection{As relações empresa-empresa.}

A falta de atividades conjuntas entre as empresas é um fator predominante do arranjo local. Quase não há ligações entre as empresas, e quando estas ocorrem, são geralmente muito tênues e inconstantes. Do total de empresas da amostra, 33\% desenvolvem algum tipo de troca de informações com outras empresas e $20 \%$ estabelecem algum tipo de contato para desenvolvimento de produto. Mas estas relações ocorrem na grande maioria com os fornecedores. Não há relação entre concorrentes para o desenvolvimento de produtos. Além disso, não há nenhum tipo de ação conjunta de marketing, de capacitação de recursos humanos ou de compartilhamento de laboratórios.

A única iniciativa de estratégia conjunta entre as empresas é a formação de um consórcio de exportação do qual participam dez empresas do setor. Este consórcio, em fase de implantação, conta com o apoio do Sebrae, da Fiesp/Ciesp, da Abimo, da Sinaemo e da Apex. As empresas do consórcio exportam cerca de $1 \%$ a $2 \%$ do seu faturamento. Dentro 
deste programa estão previstos recursos para a capacitação tecnológica e para a busca de certificações internacionais.

\begin{tabular}{|l|}
\hline \multicolumn{1}{|c|}{ Tabela 4.1.} \\
\hline \multicolumn{1}{|c|}{ Empresas da Saúde Participantes do Consórcio de Exportação } \\
\hline Deltronix Equipamentos Ltda. \\
\hline Dent-Flex Ind. e Com. Ltda \\
\hline Dentscler Ind. de Aparelhos Odontológicos ltda \\
\hline \hline JP Indústria Farmacêutica S/A \\
\hline \hline JV Equipamentos Médicos e Odontológicos Ltda \\
\hline Microem Produtos Eletrônicos Ltda \\
\hline \hline Odontobrás Ind. Equip. Médicos e Odontológicos Ltda \\
\hline \hline Odontomedics Ind. Equip. Médico-Odontológico Ltda \\
\hline Olidef CZ Ind. Com. de Aparelhos Hospitalares Ltda \\
\hline \hline WEM Equipamentos Eletrônicos Ltda \\
\hline
\end{tabular}

Foi perguntado a todas as empresas se elas se interessariam por algum tipo de parceria com outras empresas da região para alguma das finalidades já citadas, ou seja, para o desenvolvimento de produtos, ações conjuntas de marketing, capacitação de recursos humanos, compras conjuntas etc. A maioria disse ter interesse, principalmente para o desenvolvimento de produtos.

Entretanto, o que foi observado nas entrevistas com os empresários é que há uma grande desconfiança quanto à formação destes grupos setoriais. Há um grande receio de que seja para benefício próprio de quem organiza ou de alguns dentro do grupo, o que faz com que alguns empresários não se interessem em participar de qualquer atividade deste tipo.

\subsubsection{As relações empresa-universidade.}

Buscou-se saber também se as empresas locais do setor mantêm alguma forma de cooperação com a universidade e seus laboratórios para o desenvolvimento de produtos ou novos processos, para a realização de testes e certificação ou para o treinamento de pessoal.

Aproximadamente $60 \%$ das empresas disseram ter algum tipo de vínculo com a universidade no desenvolvimento de produtos e processos, $42 \%$ para a realização de testes 
e $17 \%$ para treinamento de pessoal. Mas os dois primeiros tipos de relações ocorrem apenas de maneira informal, ou seja, através de conversas com professores das faculdades e através do empréstimo dos equipamentos para que algum professor conhecido use por algum tempo e faça algumas sugestões. Mesmo assim, as empresas reclamaram que é difícil de se conseguir até mesmo este tipo de relação informal. Várias disseram que já tentaram fazer este tipo de contato com a universidade e não obtiveram resposta. As principais reclamações foram quanto à burocracia, a falta de cumprimento dos prazos, a falta de continuidade das relações e a falta de interesse por parte da universidade.

Algumas empresas até mesmo desconhecem em que a universidade poderia ajudar. Apesar disso, várias empresas disseram ter interesse neste tipo de parceria, principalmente para o desenvolvimento de produtos, para a realização de testes e para a certificação de produtos.

\subsubsection{As relações empresa - sindicato de fabricantes.}

Foi perguntado às empresas que tipo de vínculo elas possuem com as associações de classe ou o sindicato de fabricantes. Os resultados obtidos foram: $62 \%$ das empresas realizam troca de informações, $31 \%$ das empresas disseram que o sindicato apóia a realização de feiras e eventos e $25 \%$ disseram participar de cursos e seminários. Entretanto, as empresas não consideram importante o tipo de interação com estas entidades, ou melhor, não existe um vínculo participativo forte entre as empresas e estes órgãos. Com exceção do consórcio de exportação, que teve o apoio da associação dos fabricantes (Abimo) e da Fiesp/Ciesp, não há nenhuma mobilização no sentido de organizar ações conjuntas entre as empresas.

\begin{tabular}{|l|c|}
\hline \multicolumn{2}{|c|}{ Tabela 4.2. } \\
\hline Serviços Oferecidos pelos Sindicatos de Fabricantes & \% de Empresas \\
\hline \hline Troca de informações & 62 \\
\hline \hline Realização de feiras e eventos & 31 \\
\hline \hline Cursos e seminários & 25 \\
\hline \hline Apoio na aquisição de insumos & 0 \\
\hline Negociações coletivas & 0 \\
\hline
\end{tabular}

As entidades das quais fazem parte estas empresas são a ABIMO (Associação dos Fabricantes de Produtos Médicos e Odontológicos), o SINAEMO (Sindicato da Indústria de Artigos e Equipamentos Odontológicos, Médicos e Hospitalares do Estado de São 
Paulo), o CIESP (Centro das Indústrias do Estado de São Paulo) e a ACI (Associação Comercial e Industrial de Ribeirão Preto).

\subsubsection{As relações empresa - escolas técnicas.}

Do total de empresas da amostra, 13 empresas (46\%) disseram utilizar os serviços do SENAI para a obtenção de informações e para a formação de mão-de-obra e 12 (43\%) disseram participar de alguns cursos e seminários oferecidos pelo Sebrae. Na opinião das empresas, o treinamento de mão-de-obra poderia ser mais direcionado para o setor, a fim de se ter trabalhadores melhor qualificados. Quanto ao Sebrae, as empresas disseram que poderia ser melhorada a qualidade dos cursos, e que fossem oferecidos cursos de marketing, gestão entre outros. Boa parte das empresas mostrou interesse em participar de cursos e eventos de formação em áreas administrativas.

\subsubsection{Origens.}

Dois fatores parecem se sobressair quando se fala da origem das empresas do setor da saúde no município. Em primeiro lugar, a maioria das empresas foi constituída por exfuncionários de empresas mais antigas situadas no município. No setor médico várias surgiram de empresas que já não existem mais. No setor odontológico, principalmente uma empresa maior deu origem a várias outras. Um segundo fator importante é a presença da universidade. Algumas empresas foram formadas por pessoas que trabalhavam nos laboratórios de pesquisa da USP, ou por professores das faculdades.

\subsubsection{Vantagens Locacionais.}

Foi pedido também às empresas que indicassem as vantagens de estarem localizadas em Ribeirão Preto. Os itens foram apresentados às empresas para que assinalassem os que poderiam ser considerados como vantagens. Poucas empresas fizeram algum comentário sobre o grau de importância de cada item. Curiosamente, um grande número de empresas apontou os centros de pesquisa como uma vantagem do município, apesar de não ser apontado como fator principal por nenhuma empresa. No entanto, nas questões anteriores elas disseram quase não utilizar os serviços destes centros. 
A proximidade de fornecedores e de outras empresas do setor foram considerados dois fatores fortes da competitividade da indústria local. O item mão-de-obra qualificada foi indicado como fator de média importância na distinção da competitividade do setor industrial da saúde no município.

\begin{tabular}{|l|c|}
\hline \multicolumn{2}{|c|}{ Tabela 4.3. } \\
\hline \multicolumn{1}{|c|}{ Vantagens Locacionais de Ribeirão Preto } \\
\hline Proximidade de outras empresas do setor & $\boldsymbol{N}^{\circ}$ Empresas \\
\hline Proximidade de fornecedores & 17 \\
\hline Centros de pesquisa & 16 \\
\hline \hline Proximidade do mercado consumidor & 11 \\
\hline Mão de obra qualificada & 11 \\
\hline
\end{tabular}

As empresas indicaram como principais desvantagens locacionais de Ribeirão Preto: a guerra fiscal entre os estados, a falta de mão-de-obra qualificada e a falta de uma política municipal de incentivo ao setor.

\subsubsection{Políticas de Apoio.}

Foram apresentadas aos empresários várias medidas de incentivo coletivo ao setor para que indicassem as mais adequadas para contribuir para o desenvolvimento setorial no município.

Na tabela 4.4. estão as medidas propostas e o número de firmas que disseram considerá-las importante para o desenvolvimento do setor. Em geral, todas as alternativas propostas foram vistas como positivas pelos empresários. As empresas consideram que a divulgação da imagem da cidade como centro tecnológico da saúde, além de favorecer o aumento das vendas, pode contribuir para a atração de mão-de-obra qualificada. 


\begin{tabular}{|l|c|}
\hline \multicolumn{1}{|c|}{ Tabela 4.4. } \\
\hline \multicolumn{1}{|c|}{ Políticas para o Desenvolvimento Setorial } & N $^{\circ}$ Empresas \\
\hline Articular feiras e missões comerciais & 20 \\
\hline Articular novos cursos de qualificação profissional & 19 \\
\hline $\begin{array}{l}\text { Apoiar na elaboração de projetos de investimento e busca de recursos } \\
\text { financeiros }\end{array}$ & 19 \\
\hline $\begin{array}{l}\text { Colaborar na coordenação empresarial para: políticas de compra conjunta, } \\
\text { consórcio exportador etc. }\end{array}$ & 18 \\
\hline Desenvolver o selo Ribeirão Preto & 15 \\
\hline Divulgação da cidade & 14 \\
\hline Fundo de aval para pequenas empresas & 14 \\
\hline Contribuir para a articulação de um fundo de capital de risco regional & 10 \\
\hline Outras & 6 \\
\hline
\end{tabular}

Enfim, a organização das empresas para a busca de parcerias, tanto as parcerias entre as empresas como entre estas e a universidade, as entidades de classe e o setor público, pode contribuir para o aumento da competitividade das empresas locais e criar significativas vantagens para o setor produtivo local.

\subsection{Os Centros de Pesquisa.}

Os centros de pesquisa entrevistados pertencem às faculdades de Odontologia, Farmácia, Biologia e Química, e os laboratórios do Departamento de Física e Matemática da Faculdade de Filosofia, Ciências e Letras da Universidade de São Paulo, campus de Ribeirão Preto, além da Fundação Hemocentro, situada no mesmo campus desta universidade. A Faculdade de Medicina não respondeu ao questionário.

Nos questionários enviados às faculdades buscou-se inicialmente identificar sua estrutura e sua produção científica através do volume de publicações, da participação dos trabalhos em congressos, da produção de teses e dissertações e um panorama geral das vagas oferecidas para a graduação e os cursos de mestrado e doutorado.

Em seguida, perguntou-se sobre a infra-estrutura de pesquisa: os laboratórios existentes, o número de técnicos, as pesquisas em andamento, os resultados de pesquisas já realizadas, a existência de patentes registradas pelo laboratório etc. Buscou-se avaliar o tipo de relação desenvolvida com o setor privado, e em que medida ocorria a transferência do conhecimento científico para o setor produtivo. Os laboratórios foram questionados a 
respeito do potencial para o desenvolvimento de novos produtos, as áreas que identificavam como promissoras, as experiências de parceria com o setor privado e os problemas enfrentados. Foram levantadas questões sobre o interesse em se criar novas parcerias com o setor privado e como estas entidades viam a possibilidade de utilização de instrumentos de transferência do conhecimento cientifico para o setor produtivo como as incubadoras de empresas e a participação dos investidores de risco.

\section{Os Resultados:}

$\mathrm{Na}$ tabela 4.5. pode-se observar a estrutura das faculdades que fizeram parte da pesquisa, através do número de vagas oferecidas para graduação, mestrado e doutorado e o número de defesas no ano 2000. Deve-se considerar que a Fundação Hemocentro não oferece estes cursos, sendo seu principal objetivo a prestação de serviços de saúde à população, juntamente com a geração de pesquisas e conhecimento científico através dos seus laboratórios.

\begin{tabular}{|c|c|c|c|c|c|c|}
\hline \multicolumn{7}{|c|}{ Tabela 4.5} \\
\hline \multicolumn{7}{|c|}{ Número de Vagas Oferecidas pelas Faculdades } \\
\hline \multirow[t]{2}{*}{ Centros } & \multirow[t]{2}{*}{$\begin{array}{l}\text { Graduação } \\
\left(n^{\circ} \text { vagas) }\right.\end{array}$} & \multirow[t]{2}{*}{$\begin{array}{c}\text { Alunos } \\
\text { Matriculados }\end{array}$} & \multicolumn{2}{|c|}{$\begin{array}{c}\text { Pós-graduação } \\
\text { (matriculados) }\end{array}$} & \multicolumn{2}{|c|}{ Defesas em 2000} \\
\hline & & & Stricto sensu & Lato sensu & Dissertações & Teses \\
\hline Biologia & 40 & 192 & $\mathrm{nr}^{*}$ & & 16 & 12 \\
\hline Física /Mat. & 40 & 80 & $21 \mathrm{~m} * * / 6 \mathrm{~d}$ & & 8 & 5 \\
\hline Química & 40 & 245 & $66 \mathrm{~m} / 67 \mathrm{~d}$ & & 18 & 10 \\
\hline Farmácia & 50 & 249 & $56 \mathrm{~m} / 36 \mathrm{~d}$ & 5 & 16 & 3 \\
\hline Odontologia & 80 & 339 & $75 \mathrm{~m} / 31 \mathrm{~d}$ & 12 & 23 & 10 \\
\hline Hemocentro & & & & & & \\
\hline
\end{tabular}

* $\mathrm{nr}=$ não respondido

** m: mestrado; d: doutorado

Em seguida, foi investigada a capacidade de produção dos laboratórios pertencentes às faculdades e à Fundação Hemocentro, além dos resultados dessas pesquisas através das publicações, dos trabalhos apresentados em congressos e os encontros e congressos realizados por estas unidades. Infelizmente, fica inviável especificar as áreas de estudo dos artigos publicados devido ao grande volume destes e por fugir ao escopo deste trabalho. 
Tabela 4.6.

Número de Laboratórios e Pesquisas

\begin{tabular}{|l|c|c|c|c|}
\hline \multicolumn{1}{|c|}{ Centros } & $N^{\circ}$ Labotarórios & $\begin{array}{c}N^{\circ} \text { Pesq. em } \\
\text { Andamento }\end{array}$ & $\begin{array}{c}\text { Artigos Publicados } \\
\text { em 2000 }\end{array}$ & $\begin{array}{c}\text { Trabalhos Apresentados } \\
\text { em Congressos }\end{array}$ \\
\hline Biologia & 25 & 22 & 92 & 275 \\
\hline Física /Mat. & 17 & 21 & $79^{*}$ & 170 \\
\hline Química & 19 & 21 & 58 & 203 \\
\hline Farmácia & 38 & 96 & 61 & $\mathrm{Nr}$ \\
\hline Odontologia & 20 & 81 & $\mathrm{nr}$ & $\mathrm{Nr}$ \\
\hline Hemocentro & 9 & $\mathrm{nr}$ & 13 & \\
\hline
\end{tabular}

* Nos últimos 3 anos.

\begin{tabular}{|c|c|}
\hline \multicolumn{2}{|r|}{ Tabela 4.7.} \\
\hline \multicolumn{2}{|r|}{ Congressos Realizados pelos Departamentos } \\
\hline Departamentos & Congressos Realizados \\
\hline Biologia & $\begin{array}{c}\text { IV Encontro sobre Abelhas (300)* } \\
\text { I Encontro Brasileiro sobre Crustáceos }(280) \\
\text { I International Meeting on Paleoarthropology }(85)\end{array}$ \\
\hline Química & $\begin{array}{l}10^{\circ} \text { Encontro Regional de Química } \\
2^{\circ} \text { Jornada de Iniciação Científica e Tecnológica em Química (600) } \\
12^{\circ} \text { Encontro Regional de Química (226) }\end{array}$ \\
\hline Física Médica & $\begin{array}{l}\text { IV Workshop em Física Médica e Biofísica (100) } \\
\text { Primeira Escola Brasileira de Física Biológica e Médica (100) }\end{array}$ \\
\hline Farmácia & $2^{\text {nd }}$ Congress of Pharmaceutical Sciences (1200) \\
\hline Odontologia & $\begin{array}{c}\text { Jornada Odontológica de Ribeirão Preto } \\
\text { Congresso Interno de Pesquisa }\end{array}$ \\
\hline Hemocentro & \\
\hline
\end{tabular}

Até aqui pode ser observado que há uma grande capacidade de geração local de conhecimento científico, criando um ambiente favorável para o desenvolvimento tecnológico das empresas locais.

\subsubsection{Infra-estrutura de pesquisa.}

As faculdades foram questionadas quanto à infra-estrutura de laboratórios. Como pode ser observado, há uma grande capacidade de pesquisa nesses centros, tanto em termos de quantidade de laboratórios como pela variedade das áreas de pesquisa. A seguir, apresentamos uma relação dos laboratórios existentes nos departamentos. 
Odontologia - há 3 laboratórios multidisciplinares e os seguintes laboratórios didáticos: Ortodontia, Materiais Dentários e Prótese, Cerâmica, Fundição, Microscopia, Histopatologia e Anatomia, além dos seguintes laboratórios de pesquisa: o laboratório de Genética, de Eletromiografia, de Neurofisiologia, de Neuroendocrinologia, de Odontopediatria, de Ortodontia, de Endodontia, Dentística, Histopatologia Bucal e Materiais Dentários. Há também o Laboratório Integrado de Pesquisa (LIPEM), o Serviço Especializado em Radiografia e Documentação Ortodôntica (SERDO), o Laboratório de Análise e Controle da Imagem Radiográfica Odontológica (LACIRO), o Núcleo de Pesquisa em Materiais Odontológicos e o Centro de Eletromiografia,

Farmácia - a faculdade de ciências farmacêuticas possui uma infra-estrutura de 38 laboratórios de pesquisa. Em 2001 havia 96 projetos de pesquisa em andamento: 34 no Departamento de Análises Clínicas, Toxicológicas e Bromatológicas, 32 no Departamento de Ciências Farmacêuticas e 30 no Departamento de Física e Química. Há também um Centro de Estudos de Biodisponibilidade e Bioequivalência e um Núcleo de Assistência Farmacêutica.

Biologia - fazem parte do departamento de Biologia os seguintes laboratórios: Microbiologia, Fisiologia de Crustáceos, Ecotoxicologia e Malacologia, Bicepologia de Crustáceos, Fisiologia Renal, Citogenética e Metagênese, Fisiologia vegetal, Bioquímica de Microorganismos, Sistemática de Peixes e Mamíferos, Biologia e Genética de Abelhas, Morfologia e Evolução de Insetos, Fitoquímica, Bioquímica, Neuroquímica, Genética de População, Ecologia de Abelhas, Sistemática e Ecologia de Vegetais, Sistemática de Angiosperma, Genética de Abelhas, Entomologia Aquática. Há também os laboratórios novos de: Biologia Molecular, Zoologia de Vertebrados, Fisiologia de Crustáceos e Biologia Celular/Microbiologia e de Limnologia.

Física e Matemática (FFCL-RP) - possui a seguinte infra-estrutura de laboratórios: Neurociência Computacional, Computação de Imagens, Física Estatística, Materiais Cerâmicos e Biossensores, Separação Química, Fotobiofísica, Preparação de Amostras, Caracterização Elétrica, Cristalografia, Análise de Materiais, EPR - Ressonância Magnética, Biomateriais e Imagem por NMR, Biomagnetismo, Biomagnetismo (sala blindada), Computação, Biofísica e o Centro de Instrumentação, Dosimetria e Radioproteção (CIDRA).

Química (FFCL-RP) - o departamento de química possui 19 laboratórios: laboratório de Análises Espectrométricas (Ressonância Magnética Nuclear, Espectrometria de Massas, 
Espectroscopia de Infravermelho e Ultra-violeta), laboratório de Bioinorgânica, laboratório de Bioquímica, de Eletrocatálise, de Eletroquímica e Eletrocatálise, de Eletrossíntese Orgânica, de Físico-Química de Colóides e Superfície, de Físico-Química de Compostos Intercalados, laboratório de Físico-Química de Materiais Eletródicos e Desenvolvimento de Baterias de Íons de Lítio, laboratório de Fotoquímica e de Processos Fotofísicos em Biopolímeros, laboratório de Fotoquímica Inorgânica, laboratório de Fotoquímica Orgânica, de Modelagem Molecular, de Química Ambiental, de Química Analítica, de Química Inorgânica, de Simulação Molecular, de Síntese de Compostos Organocalcogênios e de Síntese Orgânica.

Hemocentro - fazem parte do Hemocentro os seguintes laboratórios: Hematologia e Oncologia, Biologia Molecular, Biologia Celular, Imunologia, Virologia, Bioinformática, Sorologia, Imuno-Hematologia, Fracionamento e o laboratório de Clonagem.

Mais uma vez, o potencial de produção científica destes laboratórios reforça a idéia de que há uma variedade enorme de possibilidades de parcerias com o setor produtivo, com benefícios para ambos.

\subsubsection{Patentes registradas.}

Observa-se poucos pedidos de patentes em relação ao que é produzido, do que decorre duas hipóteses: se por um lado este fato pode significar a falta de pesquisas inovadoras, por outro, pode ser resultado de uma cultura ainda tímida quanto à importância de se patentear os novos produtos e processos desenvolvidos nas universidades brasileiras. Além disso, como há um custo elevado para manter a patente de um produto, isto pode se tornar inviável se não se tem perspectivas de ganhos, o que poderia ocorrer através da comercialização do produto. Os laboratórios pertencentes às faculdades de Odontologia, Farmácia e Biologia e os laboratórios do Departamento de Física e Matemática disseram não haver pedidos registrados de patentes. Ou seja, de todos os laboratórios consultados, apenas os laboratórios do Hemocentro e os da Faculdade de Química declararam haver algum pedido de patente nos seguintes processos:

Na Faculdade de Química houve um pedido de privilégio no final de 1987 pelo trabalho de síntese de supercondutores a partir da xenotímia, além de duas patentes solicitadas em 1999 quanto ao processo de obtenção de compostos carbonáceos a partir do bagaço da 
cana-de-açúcar, e quanto ao processo de descontaminação de couro ou de seus derivados contaminados com metais pesados.

\subsubsection{Potencial para desenvolvimento de produtos.}

Quanto à percepção do potencial para o desenvolvimento de produtos, todas as faculdades, com exceção da Faculdade de Biologia, mostraram grande interesse e apontaram um caminho de vastas possibilidades para parcerias com o setor privado. Especificamos abaixo as áreas mais promissoras segundo as respostas de cada faculdade:

Odontologia - segundo a FORP, a formação científica do corpo docente e a infra-estrutura de laboratórios desta faculdade têm capacidade de atender à demanda de colaboração, dar assessoria e estabelecer parceria com o setor privado, principalmente no que se refere aos seguintes itens:

- Discussão e aplicação de normas de qualidade com vistas à conformidade para materiais de uso odontológico.

- Discutir qualidade de produtos odontológicos.

- Desenvolver ligas para uso odontológico.

- Realizar ensaios com ligas metálicas de uso odontológico.

- Desenvolver e avaliar produtos de atuação na cavidade bucal com vistas à prevenção e terapia.

- Material para regeneração cicatricial guiada.

- Aplicação de materiais para modelo à base de resina epóxica.

- Desenvolver sistemas de liberação controlada para o desenvolvimento de periodontopatias.

- Incubação de pequena indústria de materiais endodonticos.

- Possibilidade de reciclagem de resíduos que a comunidade odontológica, pública e privada, descarta no meio ambiente.

Farmácia - A formação do corpo docente juntamente com a moderna infra-estrutura de laboratórios possuem capacidade para o desenvolvimento de produtos farmacêuticos, cosméticos, veterinários, odontológicos e dermatológicos nos seguintes aspectos: adequação de formulação, determinação do prazo de validade, pesquisa e desenvolvimento 
de medicamentos similares, genéricos e sistema de liberação (transdérmicos, injetáveis, desagregação entérica, bioadesivos etc.) para as mais diversas terapias.

Além destes itens citados, nos laboratórios desta faculdade estão em andamento projetos na área de tratamento de câncer sistêmico e de pele, terapia gênica, reposição hormonal, antiinflamatória e anti-parasitária entre outros.

Física e Matemática (FFCL-RP) - segundo este departamento, um grande número de pesquisas desenvolvidas, ou em desenvolvimento, apresentam resultados que, em parcerias convenientes, levariam à fabricação e comercialização de uma série de instrumentos e equipamentos para uso na área da saúde. As áreas médica e odontológica seriam o alvo principal, além dos laboratórios que trabalham com materiais biológicos, que também seriam possíveis beneficiários dos produtos desenvolvidos. Enfim, muitas das dissertações de mestrado e teses de doutorado desenvolvidas no departamento de Física e Matemática apresentam resultados sugerindo modelos de instrumentação específica para a área médica e odontológica.

Química (FFCL-RP) - o Departamento de Química realiza pesquisas de ponta nas áreas de Bioquímica, Físico-Química, Química Analítica, Química Inorgânica, Química Orgânica e Química Tecnológica. Em virtude disso, este Departamento possui recursos materiais e humanos para desenvolver novos produtos em: novos materiais com diferentes tipos de aplicações, novos tipos de baterias, diferentes tipos de biossensores, novos fármacos e outros produtos naturais ou artificiais com propriedades biológicas úteis, novos catalisadores que possibilitem a realização de diferentes tipos de reações químicas e bioquímicas. Além disso, pode também prestar os mais variados tipos de serviços para a comunidade, além da realização de modelagens moleculares de diferentes tipos de sistema. Conforme a visão do próprio departamento, várias áreas poderiam ser beneficiadas pelo desenvolvimento dos seus produtos.

Hemocentro - a Fundação Hemocentro não respondeu a esta questão. No entanto, a direção desta Fundação mostrou-se profundamente interessada no desenvolvimento de parcerias com o setor privado, inclusive com a intenção de se criar uma incubadora de empresas vinculada à Fundação para o desenvolvimento dos projetos de pesquisa deste Centro. 


\subsubsection{Experiências de trabalho em parceria com o setor privado.}

Apesar da grande receptividade quanto à possibilidade de parcerias com o setor privado para o desenvolvimento de projetos de novos produtos e processos para o mercado, em geral estes laboratórios possuem poucas experiências de trabalho com o setor privado. Este fato talvez possa ser explicado em parte pelas dificuldades impostas pela Universidade para este tipo de relação público-privada.

No entanto, para os que tiveram este tipo de experiência, os resultados foram favoráveis, como é o caso de estudos da Faculdade de Odontologia, conjuntamente com a Faculdade de Odontologia da UNESP Araraquara e com a Faculdade de Medicina da USP Ribeirão Preto, que forneceram resultados que levaram à industrialização da pasta Calen, pela S.S. White Artigos Dentários Ltda - Rio de Janeiro.

Posteriormente, o aprimoramento destes estudos teve como resultado a industrialização da pasta Calen PMCC, ambos produtos amplamente utilizados e aceitos pelos profissionais da área. Recentemente a FORP-RP iniciou trabalhos sobre contaminação microbiana de escovas dentais, testando métodos de desinfecção. Em 2001 tiveram início vários trabalhos em colaboração com a Faculdade de Ciências Farmacêuticas da USP, inclusive avaliando, a pedido da Empresa Dentox Limited (Reino Unido), testes in vitro e in vivo de novos produtos para esta finalidade.

A Faculdade de Química foi a que mais apresentou parcerias com o setor privado, entre estas estão:

- Desenvolvimento e aplicação de métodos analíticos para análises de matériasprimas e produtos de origem natural ou industrial.

- Desenvolvimento de produtos com ação enzimática para a higienização de material cirúrgico.

- Realização de testes de pureza de produtos farmacêuticos e de produtos enzimáticos utilizados para fins industriais.

- Elaboração de laudos técnicos sobre a qualidade de produtos industriais.

- Síntese de princípios ativos para diversos tipos de fármacos.

- Realização de modelagens moleculares de diferentes sistemas naturais e biológicos.

- Prestação de serviços de consultoria para o desenvolvimento de novos processos industriais e/ou melhorias de processos industriais já existentes. 
- Prestação de serviços de assessoria para a organização de infra-estrutura e planejamento das atividades necessárias para a implantação e funcionamento de cursos técnicos de nível médio e superior na área de Química e Bioquímica.

O Hemocentro, juntamente com o Departamento de Física e Matemática disseram ter poucas experiências com o setor privado. Na visão da Fundação Hemocentro, as relações com o setor privado são pequenas tendo em vista o potencial existente naquele centro. Para esta Fundação, o intercâmbio com o setor privado seria de extrema valia quanto à colocação de novos laboratórios, equipamentos e mão-de-obra especializada para dar apoio às atividades de saúde. Este centro demonstrou grande interesse em participar de projetos desse tipo. No caso do departamento de Física e Matemática, este apontou para o fato de que as tentativas de realizar estas parcerias, através do Centro de Dosimetria e Radioproteção (CIDRA) receberam pouca receptividade por parte do setor privado. As faculdades de Farmácia e a Biologia não responderam esta questão.

Quanto às dificuldades nas parcerias com o setor privado, a Faculdade de Química ressalta principalmente: a falta de continuidade do trabalho iniciado, a ausência de objetivos de longo prazo por parte do setor produtivo e a discordância com relação a custos e prazos dos serviços prestados. As outras unidades não se manifestaram a este respeito.

\subsubsection{Formas possíveis de relação com o setor privado.}

As faculdades foram questionadas quanto às formas possíveis de relação com o setor privado. As respostas foram no sentido da proposição de convênios para o desenvolvimento de projetos de pesquisa, na criação de produtos, na prestação de serviços, na oferta de assessoria e consultoria, palestras, cursos, seminários, congressos e feiras, ou seja, as faculdades demonstram interesse em realizar uma ampla gama de atividades com o setor privado.

O Departamento de Física e Matemática apresentou uma proposta de uso compartilhado dos seus laboratórios pelo setor privado, para a realização de uma série de testes e medidas que exijam aparelhos sofisticados, os quais muitas vezes o setor privado não dispõe, enquanto os laboratórios deste departamento dispõem, inclusive, de pessoal especializado com alto nível de formação. 
Por outro lado, o Departamento de Física e Matemática ressaltou que seus serviços foram oferecidos durante o "Encontro de Fabricantes de Equipamentos Médicos e Odontológicos" em maio de 2000, realizado no município, e que os diversos segmentos empresariais que tomaram conhecimento desses serviços, mostraram interesse e manifestaram o desconhecimento do potencial que o departamento oferecia, no entanto, nunca houve nenhuma procura do setor privado desde aquela data.

A Faculdade de Química foi mais específica na sua resposta, dizendo ter interesse de parcerias nas seguintes áreas: prestação de serviços de consultoria nas áreas de química, bioquímica e ambiental; realização de análises químicas e ambientais de diversos tipos; pesquisa de novos métodos sintéticos para a obtenção de determinados produtos e matérias-primas; preparação de novos produtos com diferentes aplicações (princípios ativos de fármacos, catalisadores, biossensores, eletrodos etc.); realização de testes químicos sobre segurança de processos e descarte de resíduos industriais e, reciclagem, atualização e formação de mão-de-obra qualificada.

Além de ter demonstrado interesse na criação de novas parcerias, a Faculdade de Farmácia já possui um Centro de Biodisponibilidade e Bioequivalência que visa atender a demanda das indústrias farmacêuticas para o registro de medicamentos genéricos, de acordo com as exigências de regulamentação de medicamentos genéricos da ANVISA.

Apenas a faculdade de Biologia não respondeu a esta questão.

\subsubsection{Importância dos seguintes instrumentos para o desenvolvimento tecnológico: 1) incubadora de empresas, 2) fundo de capital de risco e 3) auxílio na busca de recursos.}

As faculdades e departamentos foram interrogados quanto à importância dos três instrumentos citados acima para o desenvolvimento tecnológico. No item incubadora de empresas, as faculdades de Química e Farmácia consideraram este instrumento essencial para possibilitar a instalação e o desenvolvimento de novas pequenas e micro empresas, principalmente em uma área de alta tecnologia como a área da saúde. Segundo estas entidades, alunos e profissionais recém formados com projetos de desenvolvimento de produtos poderão ver seus projetos viabilizados através da incubadora de empresas. Além disso, viram a possibilidade dos docentes poderem assessorá-los cientificamente no desenvolvimento desses projetos. 
O departamento de Física e Matemática disse desconhecer o funcionamento das incubadoras de empresas enquanto as faculdades de Biologia, Odontologia e a Fundação Hemocentro não responderam a esta questão.

No item 2, papel dos fundos de capital de risco, apenas o Departamento de Química mostrou conhecer este instrumento de financiamento, demonstrando interesse. $\mathrm{O}$ departamento de Física e Matemática disse desconhecer este instrumento e as outras unidades interrogadas não responderam a esta questão.

Quanto ao último item, sobre como as faculdades vêem o auxílio na busca de recursos, as faculdades de Farmácia, Química e o Departamento de Física e Matemática consideram de importância fundamental o auxílio na busca de recursos, inclusive considerando que a universidade da qual fazem parte é uma grande captadora de recursos financeiros junto às entidades nacionais e estaduais como FAPESP, CAPES, CNPq, FINEP, PADCT, PRONEX, Banco do Brasil e internacionais como o Banco Mundial, as Fundações Internacionais e os Programas Temáticos Multi-Institucionais.

Para estas faculdades, estes recursos poderiam auxiliar nas parcerias com o setor privado, como por exemplo, o Programa RHAE - Programa de Capacitação de Recursos Humanos para Atividades Estratégicas - do CNPq e os Programas PITE - Parceria para a Inovação Tecnológica, PIPE - Pesquisa Inovadora em pequenas empresas e CONSITEC Consórcios Setoriais para Inovação Tecnológica - da FAPESP.

As faculdades de Odontologia, Biologia e a Fundação Hemocentro não responderam à questão.

As questões levantadas nesta seção demonstraram que há um grande potencial para o desenvolvimento de parcerias público-privadas e para a criação de uma extensa rede de transferência de conhecimento universidade-empresa. Quase todos os departamentos vêem com entusiasmo as perspectivas de parcerias com o setor privado. A utilização dos centros de pesquisa para o desenvolvimento de produtos de mercado é algo que poderia ser muito mais explorado, com benefícios para o setor produtivo e para a sociedade como um todo, podendo trazer aumento na geração de emprego, incorporação de inovações tecnológicas no setor produtivo e criando novos mercados. 


\section{Considerações Finais}

Como vem sendo destacado nos trabalhos recentes sobre desenvolvimento regional, a criação dos clusters tem impulsionado o desenvolvimento econômico onde estes estão localizados. Como vimos, as vantagens da organização da capacidade produtiva em clusters vêm tanto pela geração de economias externas e, portanto, não propositais, como pela associação estratégica das firmas, possibilitando um salto de competitividade na colocação destas firmas no mercado.

O município de Ribeirão Preto é conhecido como um importante centro de referência na área da saúde, tanto pela prestação de serviços, com um número considerável de clínicas de diversas especialidades e de hospitais, como pela presença das faculdades relacionadas às áreas da saúde. Além disso, a cidade também é conhecida pela concentração de empresas fabricantes de produtos e equipamentos da área médica, hospitalar, odontológica e laboratorial.

A indústria da saúde em Ribeirão Preto contempla os 5 setores da classificação da ABIMO, que são: o setor de implantes e material de consumo médico-hospitalar; o setor de equipamentos médico-hospitalares; o setor de odontologia; o setor de radiologia e diagnóstico por imagem; e o setor de laboratórios, com empresas fabricantes de equipamentos para laboratórios, reagentes e outros.

Podemos dizer que o surgimento da concentração de indústrias do setor da saúde em Ribeirão Preto se aproxima em muito da abordagem dos acidentes históricos de Krugman (1998). Há várias empresas no município que foram constituídas por ex-funcionários de empresas locais mais antigas. No setor médico várias surgiram de empresas que já não existem mais. No setor odontológico, este fator é ainda mais marcante, onde uma empresa fundada na década de 40 deu origem a várias outras. Além disso, a presença da universidade, e principalmente das faculdades de Medicina e Odontologia, possibilitou a formação de mão-de-obra especializada para o surgimento de várias empresas.

Se um acidente histórico deu início à indústria local da área da saúde, outros fatores como a demanda vinda das clínicas e dos hospitais locais, a facilidade de escoamento da produção e a facilidade de acesso aos fornecedores, principalmente situados na capital paulista, possibilitaram o desenvolvimento desta indústria. Além disso, a formação de uma mão-de-obra local, o desenvolvimento de um conhecimento tácito e de um mercado fornecedor de serviços terceirizados foram importantes para manterem as vantagens da 
localização destas empresas no município. Também a presença da universidade contribuiu neste processo, devido principalmente ao fato de que várias firmas foram criadas por exprofessores e funcionários e, além disso, a universidade pode ser vista como um mercado consumidor exigente, servindo de estímulo para as inovações dos produtos.

No entanto, a concentração de indústrias da área da saúde em Ribeirão Preto só pode ser caracterizada como um cluster no sentido amplo da palavra, ou seja, com poucas considerações sobre as relações estratégicas entre os agentes locais. As questões levantadas pela pesquisa de campo mostraram que há um baixo grau de cooperação entre os agentes produtivos, com eficiências coletivas ainda não exploradas, apontando para um grande espaço de desenvolvimento da indústria neste sentido.

Outra característica observada na indústria local ligada à área da saúde é a forma como ocorre o processo inovativo. Através da pesquisa de campo fica claro que o desenvolvimento tecnológico desta indústria ocorre em grande parte pela interação com os clientes e fornecedores e, em menor grau, este processo ocorre também através de transferência de conhecimento dos laboratórios das faculdades para o setor produtivo.

O tipo de relação entre firmas do setor da saúde em Ribeirão Preto se aproxima mais das interações verticais entre usuários e produtores destacadas por Lundvall (1988) que das relações horizontais apresentadas por DeBresson (em Silva, 2000). Quase não há relações horizontais de parceria entre as firmas locais, nem entre concorrentes nem com empresas atuantes em segmentos diferentes.

Neste sentido, a cooperação entre as firmas pode desempenhar um papel fundamental no processo de inovação, aumentando suas capacidades competitivas e criando maior capacidade de investimento e de maior difusão do conhecimento.

Entre as perspectivas de ação estratégica das empresas dentro dos arranjos locais, estas podem se associar ao poder público local e às instituições locais na proposição de projetos de desenvolvimento da estrutura produtiva. Além disso, a concentração de várias empresas na produção de alguns segmentos dentro do setor, como a fabricação de peças de mão, de bisturis eletrônicos e de detectores fetais pode criar a possibilidade de ações conjuntas como a pesquisa de novos produtos nesta área.

Em conformidade com as questões levantadas no capítulo 4, as possibilidades de ações para o setor poderiam ir no sentido de solucionar as falhas individuais das empresas, por um lado, e no sentido da organização das empresas para o fortalecimento do cluster. 
As necessidades de maior urgência para as firmas individuais seriam a regularização da situação das empresas em relação aos registros no Ministério da $\operatorname{Saúde}^{21}$, a busca de soluções quanto aos problemas relativos à vigilância sanitária municipal, a proposição de cursos de formação de mão-de-obra direcionados para o setor, a organização de cursos de capacitação empresarial, a criação de serviços de apoio à busca de financiamentos e a divulgação dos produtos oferecidos pelas agências de financiamento tecnológico.

Por outro lado, o fortalecimento do cluster poderia ocorrer através da organização das empresas na busca de apoio do setor público e das instituições interessadas para a realização de feiras, para a formação de novos grupos de empresas para consórcios de exportação, para a divulgação do nome da cidade como Pólo Avançado da Saúde entre outros. Além disso, as empresas poderiam se organizar na busca de novas parcerias com a universidade, tanto para o desenvolvimento de produtos como para a realização de testes.

Enfim, este trabalho buscou caracterizar a indústria local da saúde nos seus diversos aspectos e ao mesmo tempo caracterizar o arranjo produtivo local nas suas características que o aproximam ou o distanciam dos clusters. As considerações que podem ser feitas são que, apesar das limitações apresentadas pelas empresas locais, há grandes perspectivas para o desenvolvimento deste setor no município.

\footnotetext{
${ }^{21}$ Esta medida é pré-requisito para que se consiga realizar várias outras medidas, como o consórcio de exportação, por exemplo.
} 


\section{ANEXO I - Questionário Enviado para as Empresas da Área da Saúde do Município}

de Ribeirão Preto.

\section{Identificação:}

Nome da Empresa:

Endereço: Bairro:

Nome do Entrevistado:

Cargo:

Telefone: .

Porte da Empresa - Número de Funcionários:

Origem do capital: ( ) nacional; ( ) estrangeiro; ( ) misto

\section{Questionário:}

1) Principais linhas de produto e participação no faturamento

2) Distribuição das vendas - mercado interno e externo - por linha de produto.

\begin{tabular}{|l|l|l|}
\hline Produto & Merc. Interno (\%) & Merc. Externo (\%) \\
\hline & & \\
\hline & & \\
\hline & & \\
\hline & & \\
\hline
\end{tabular}

3) Distribuição das vendas no mercado interno - Setor Público e Setor Privado.

\begin{tabular}{|l|l|l|}
\hline Produto & Setor Público (\%) & Setor Privado (\%) \\
\hline & & \\
\hline & & \\
\hline & & \\
\hline & & \\
\hline
\end{tabular}


4) Discriminar os principais tipos de demandantes: hospitais, consultórios, laboratórios, outras indústrias, distribuidores (atacadistas), varejo, etc.

5) Principais regiões/países para o qual exporta.

6) Participação de componentes importados (no custo total com insumos) por linha de produto.

\begin{tabular}{|l|l|}
\hline Linha de Produtos & Part (\%) de insumos importados \\
\hline & \\
\hline & \\
\hline & \\
\hline & \\
\hline
\end{tabular}

7) Origem dos produtos importados.

8) Estrutura de mercado em que opera a empresa, segundo linhas de produto: concorrencial (muitos produtores); oligopólio (até 5 produtores); monopólio (1 produtor). (OBS pretende-se saber se poucas empresas dominam o mercado).

\begin{tabular}{|c|c|c|}
\hline Produto & $\begin{array}{c}\text { Número aproximado de } \\
\text { fabricantes }\end{array}$ & $\begin{array}{c}\text { Part. Aproximada das cinco } \\
\text { maiores no mercado nacional }\end{array}$ \\
\hline & & \\
\hline & & \\
\hline & & \\
\hline
\end{tabular}


9) Outros participantes no mercado:

Empresas nacionais de grande porte:

Empresas nacionais de pequeno porte

Empresas estrangeiras de grande porte

Empresas estrangeiras de pequeno porte

10) Localização dos principais concorrentes:

Região de Ribeirão Preto

Outras regiões do Estado de São Paulo

Outros Estados (quais)

11) Participação aproximada dos produtos importados no mercado por linha de produto

\begin{tabular}{|l|l|}
\hline Produto & Particip. (\%) dos importados \\
\hline & \\
\hline & \\
\hline & \\
\hline & \\
\hline
\end{tabular}

12) Localização dos principais fornecedores

Região de Ribeirão Preto

Outras regiões do Estado de São Paulo

Outros Estados (quais)

Exterior

13) Principais dificuldades encontradas pela sua empresa para atuar no mercado interno (Explicar):

Qualidade do produto oferecido

Custo de produção

Ausência de linhas de financiamento adequadas

"guerra fiscal"

forma das licitações

cultura dos usuários

rede de distribuição

marketing 
rede de assistência técnica

"pacotes integrados dos concorrentes" (venda/financiamento/assistência, etc.)

defasagem tecnológica

legislação/regulamentações no setor (sanitária, médica, ambiental, etc)

facilidades para importados

Outros

14) Principais dificuldades para entrar no mercado externo (Explicar):

Qualidade do produto oferecido

Custo de produção

Ausência de linhas de financiamento adequadas

cultura dos usuários

rede de distribuição

marketing

rede de assistência técnica

"pacotes integrados dos concorrentes" (venda/financiamento/assistência, etc.)

defasagem tecnológica

legislação/regulamentações no setor (sanitária, médica, ambiental, etc)

barreiras aduaneiras

Outros

15) Pontos negativos na legislação brasileira em relação ao setor:

16) A política de compras do setor público brasileiro (nas diferentes instâncias) dificulta a participação de empresas nacionais? Explique. 
17) Principais dificuldades/problemas da empresa:

Gestão

Mão-de-obra (em que nível e de que tipo)

Marketing

Tecnologia

Outros

18) Qual o percentual do faturamento que a empresa investe regularmente em pesquisa e desenvolvimento?

19) Que tipo de investimentos regulares a empresa realiza:

Modernização produtiva (novos equipamentos)

Qualificação dos funcionários

Abertura de novos mercados (participação em feiras, missões comerciais, etc)

Marketing

Controle de qualidade

Desenvolvimento de novos produtos

Novas técnicas de gestão

Outros.

20) Experiências em áreas tecnológicas:

Licenciamento de tecnologia

Adaptação tecnológica

Desenvolvimento de novos produtos

Desenvolvimento de processos

Parcerias com universidades e centros de pesquisa (pesquisa, uso de laboratórios, consultoria, treinamento, etc.)

Utilização de recursos de financiamento tecnológico (FINEP, FAPESP, outros)

Outras

21) Avaliação da mão de obra

funcionários com pós-graduação - mestrado e doutorado (áreas de atuação)

funcionários com cursos de especialização (MBA)

funcionários com superior completo (áreas) 
profissionais envolvidos em pesquisa e desenvolvimento.

22) Tipos de certificação obtidas ( ISO 9000, ISO 14000, ministério da saúde, etc)

23) Quais as formas de interação que a empresa mantém com as associações de classe ou o sindicato de fabricantes. Comentar o grau de importância e se existe alguma constância na cooperação:

Troca de informações

Realização de feiras e eventos

Cursos e seminários

Apoio na aquisição de insumos

Negociações coletivas

Outros

24) A empresa desenvolve algum tipo de atividade conjunta com outras empresas? Caso desenvolva, são empresas da região? Quais tipo de atividade?

Troca de informação

Desenvolvimento de produtos

Atividades ligadas à exportação

Ações conjunta de marketing

Ações conjunta para capacitação de RH

Utilização de laboratórios

Outros

25) A empresa se interessaria por algum tipo de parceria com outras empresas da região para alguma das finalidades citadas na questão anterior? Quais?

26) A empresa utiliza serviços ou possui convênios com entidades de suporte empresarial e escolas técnicas (Sebrae, Senai etc)? De que tipo e para qual finalidade.

27) Na opinião da empresa, o que poderia ser oferecido por estas instituições de apoio para melhorar o desempenho da empresa? 
28) A empresa mantém alguma forma de cooperação com a universidade ou centros de pesquisa? Especificar o grau de importância:

Desenvolvimento de produtos e processos

Testes e certificação

Treinamento de pessoal

Outros

29) Caso a empresa não tenha nenhum tipo de cooperação com a universidade, especificar o motivo. Em que a universidade poderia ajudar?

30) Vantagens Locacionais de Ribeirão Preto:

proximidade do mercado consumidor

proximidade de fornecedores

mão de obra qualificada

centros de pesquisa

proximidade de outras empresas do setor

outros

31) Qual é o fator distintivo de Ribeirão Preto que favorece a presença de empresas do setor?

32) Desvantagens locacionais de Ribeirão Preto. Qual é o principal problema de Ribeirão Preto para desenvolver empresas do setor?

33) Que tipo de políticas locais poderiam contribuir para o desenvolvimento do setor:

política de compras pelo poder municipal

divulgação da cidade

desenvolver o selo "Ribeirão Preto" como forma de ampliar o marketing das empresas do município

apoio na elaboração de projetos de investimento e busca de recursos financeiros

articulação de feiras e missões comerciais

fundo de aval para pequenas empresas

contribuir para articulação de um fundo de capital de risco (venture capital) regional

articular novos cursos de qualificação profissional 
colaborar na coordenação empresarial para: políticas de compra conjunta, consórcio exportador, etc.

outras. 


\section{ANEXO II - Roteiro de Informações Enviado para as Unidades de Ensino da Universidade de São Paulo campus de Ribeirão Preto.}

1. CURSOS (graduação e pós-graduação).

2. Vagas oferecidas (graduação e pós-graduação).

3. Alunos matriculados (graduação e pós-graduação).

4. Alunos Formados/ano (graduação e pós-graduação).

5. Quantidade de Dissertações e teses (se possível, colocar a área de concentração).

6. Publicações.

7. Realizações de Congressos (dias, número de participantes e local de realização).

8. Infra-estrutura da pesquisa (laboratórios existentes, número de pesquisas, técnicos etc.).

9. Pesquisas em andamento.

10. Resultados de Pesquisas Desenvolvidas.

11. Patentes Registradas.

12. Potencial para Desenvolvimento de Produtos e quais as áreas promissoras.

13. Quais as experiências de trabalhos realizadas em parceria com o setor privado e quais os problemas enfrentados?

14. Quais as formas possíveis de relação com o setor privado?

15. Como poderia se dar a inserção no projeto "PÓLO AVANÇADO DE SAÚDE ${ }^{22 » ? ~}$

16. Qual a importância dos seguintes instrumentos para o desenvolvimento tecnológico:

a) Incubadora de Empresas.

b) Fundo de capital de risco.

c) Auxílio na busca de recursos.

17. Outros Comentários.

${ }^{22}$ Este trabalho serviu de base para o Programa Pólo Avançado da Saúde, da Prefeitura Municipal de Ribeirão Preto. 


\section{Bibliografia}

ABIMO (Associação Brasileira da Indústria de Artigos e Equipamentos Médicos, Odontológicos, Hospitalares e Laboratoriais). www.abimo.org.br

ALDEN, J. (1996). Urban Development Strategies: The Challenge of Global to Local Change for Strategic Responses. University of Wale, Cardiff, UK.

Altenburg, T \& MEYer-STAMER, J. (1999). How to Promote Clusters: Policy Experiences from Latin America. In Clusters e Sistemas Locais de Inovação: Estudos de Casos e Avaliação da Região de Campinas. IE/UNICAMP, setembro, 1999.

AUDRETSCH, D.B. (1998). Agglomeration and the location of innovative activity. Oxford Review of Economic Policy 14 (2), Summer apud SUZIGAN, W.; FURTADO, J.; GARCIA, R. \& SAMPAIO, S.E.K. (2000). Aglomerações Industriais no Estado de São Paulo. ANPEC, XXVIII Encontro Nacional de Economia, Campinas, dezembro.

BASTOS, M.I. \& COOPER, C. (1995). Politics of Technology in Latin America. UNU/INTECH.

BENNEWORTH, P. \& CHARLES, D. (1998). The North East Pharmaceutical and Clinical Biotechnology Industries. Centre for Urban \& Regional Development Studies. University of Newcastle. Agosto.

BERTUGLIA, C., ed.; FISCHER, M. M., ed.; PRETO, G., ed. (1995). Technological Change, Economic Development and Space. Berlin, ed. Springer.

BEST, M. (1990) The New Competition. Cambridge, MA, Harvard University Press.

CASTRO, A. B. \& PROENÇA, A. (2001). Novas Estratégias Indústriais: Sobrevida ou Inflexão? UFRJ. Maio.

CASTRO, A. B. (2001). A Reestruturação da Indústria Brasileira nos Anos 90. Uma Interpretação. Revista de Economia Política, julho/setembro.

CÂMARA DE COMÉRCIO DO MERCOSUL.

CASSIOLATO, J. E. \& LASTRES, H. M. M. (1998). Inovação, Globalização e as Novas Políticas de Desenvolvimento Industrial e Tecnológico. In Clusters e Sistemas Locais de Inovação: Estudos de Casos e Avaliação da Região de Campinas. IE/UNICAMP, setembro, 1999. 
CASSIOLATO, J. E. \& LASTRES, H. M. M. (2001). Aglomerações, Cadeias e Sistemas Produtivos e de Inovação. Revista Brasileira de Competitividade, ano 1, no.1, abril/julho.

CODERP - Informativo Setor Saúde em Ribeirão Preto. Fevereiro 2001.

CLARA, M.; RUSSO, F. \& GULATI, M. (2000). Cluster Development and BDS Promotion: UNIDO's Experience in India. International Conference, UNIDO.

DOSI, G. et al, ed. (1988). Technical Change and Economic Theory. New York, Pinter Publishers.

FERNANDES, A.C.A.; CÔRTES, M.R.; PINHO, M.S. \& CARVALHO, R.Q. (2000). Potencialidades e Limites para o Desenvolvimento de Empresas de Base Tecnológica no Brasil: Contribuições para uma Política Setorial. Programa de Políticas Públicas. Relatório de Pesquisa, agosto de 2000.

FURTADO, J. (s/d). A Indústria de Equipamentos Médico-hospitalares: elementos para uma caracterização da sua dimensão internacional, mímeo.

GARCEZ, C.M. D’A. (2000). Sistemas Locais de Inovação na Economia do Aprendizado: Uma Abordagegm Conceitual. Revista do BNDES, Rio de Janeiro, v.7, n.14, pg.351-366, dez.2000.

HADDAD, P.R. (1989). Economia Regional: Teorias e Métodos de Análise. Fortaleza, BNB-ETENE. Estudos Econômicos e Sociais.

IGLIORI, D.C. (2000). Economia dos Clusters Industriais e Desenvolvimento. Tese de Mestrado, Faculdade de Economia, Administração e Contabilidade, Universidade de São Paulo, São Paulo.

KUMAR, N. \& SIDDHARTHAN, N.S. (1997). Technology, Market Structure and Internationalization. UNU/INTECH.

KRUGMAN, P. (1991). Geography and Trade. Cambridge.

KRUGMAN, P. (1998). What's new about the new economic geography? Oxford Review of Economic Policy 14 (2, Summer) apud SUZIGAN, W.; FURTADO, J.; GARCIA, R. \& SAMPAIO, S.E.K. (2000). Aglomerações Industriais no Estado de São Paulo. ANPEC, XXVIII Encontro Nacional de Economia, Campinas, dezembro. 
LALKAKA, R. (1997). Lessons from international experience for the promotion of business incubation systems in emerging economies. Small and Medium Enterprises Programme, UNIDO, novembro.

LEDGERWOOD, G. \& BROADHURST, A.I. (1999). Creating Technology-based Enterprise Televillages. University of Greenwich Business School, London, UK. Cities, v.16, no.1, pp. 43-50. Elsevier Science.

LUNDVALL, B.A. (1984) Innovation as an Interactive Process: from User-Producer Interaction to the National System of Innovation. In: Dosi et alii. Technical Change and Economic Theory. London and New York: Pinter Publishers, 1988.

MELO, P.R. de S. (1999). Complexo Eletrônico: Diagnóstico e Perspectiva. Complexo Eletrônico do BNDES. Setembro.

MELO, P.R. de S.; RIOS, E.C.S.D. \& GUTIERREZ, R.M.V. (2000). Equipamentos para Hemodiálise. Complexo Eletrônico do BNDES. Setembro.

MINISTÉRIO DA SAÚDE (2000). O Setor Saúde e o Complexo da Saúde no Brasil. Unicamp. Núcleo de Estudos de Políticas Públicas.

MYTELKA, LYNN K. (2001). A New Iniciative to Strengthen Local Economies: the Cluster Bank. Programa Brasil Empreendedor Fase III, Brasília, maio.

NADVI, K. (1999) Collective Efficiency and Collective Failure: The Response of the Sialkot Surgical Instrument Cluster to Global Quality Pressures. Institute of Development Studies, Brighton, UK.

O'DONOGHUE, D. (1999). The Relationship between Diversification and Growth: Some Evidence from the British Urban System 1978 to 1991.

PORTER, M.E. (1998). Clusters and the new economics of competition. Harvard Business Review, nov-dec. apud SUZIGAN, W.; FURTADO, J.; GARCIA, R. \& SAMPAIO, S.E.K. (2000). Aglomerações Industriais no Estado de São Paulo. ANPEC, XXVIII Encontro Nacional de Economia, Campinas, dezembro.

PROGRAMA DE CAPITALIZAÇÃO DE EMPRESAS DE BASE TECNOLÓGICA. BNDES, novembro de 2000.

RAIS - Relação Anual de Informações Sociais (1999). Ministério do Trabalho. Brasília. 
RAUD, C. (1999). Indústria, Território e Meio Ambiente no Brasil: Perspectivas da Industrialização Descentralizada a partir da Análise da Experiência Catarinense. Ed. UFSC.

SANTOS, A.M.M.M. \& GUARNIERI, L.S. (2000). Características Gerais do Apoio a Arranjos Produtivos Locais. BNDES Setorial, n. 12, p. 195-204, setembro.

SCHMITZ, H. (1997). Collective Efficiency and Increasing Returns. IDS Working Paper no. 50. Institute of Development Studies, University of Sussex, Brighton, March.

SCOTT, A. (1998). The geographic foundations of industrial performance. In A. CHANDler, Jr., HAGSTROM, P. and SOlVEll, O., (eds.), The Dynamic Firm - The Role of Technology, Organization and Regions. Oxford: Oxford University Press, Chapter 16 apud SUZIGAN, W.; FURTADO, J.; GARCIA, R. \& SAMPAIO, S.E.K. (2000). Aglomerações Industriais no Estado de São Paulo. ANPEC, XXVIII Encontro Nacional de Economia, Campinas, dezembro.

SILVA, C.M. de S. (2000). Inovação e Cooperação: O Estado das Artes no Brasil. Revista do BNDES, Rio de Janeiro, v.7, n.13, pg.65-88, junho.

SILVA, C.M. de S. (2000). Política de Desenvolvimento Regional na União Européia: O que Podemos Aprender? Revista do BNDES, Rio de Janeiro, v.7, n.14, pg.125-144, dezembro.

SOUZA, J.H. \& FURTADO, A.T. (2000). Evolução do Setor de Insumos e Equipamentos Médico-hospitalares, Laboratoriais e Odontológico Brasileiro: a Década de 90. DPCT/IG/UNICAMP. Junho.

SUZIGAN, W.; FURTADO, J.; GARCIA, R. \& SAMPAIO, S.E.K. (2000). Aglomerações Industriais no Estado de São Paulo. ANPEC, XXVIII Encontro Nacional de Economia, Campinas, dezembro.

TABUCHI, T. (1998). Urban Agglomeration and Dispersion: A Synthesis of Alonso and Krugman. Journal of Urban Economics, vol. 44, no.3, novembro.

U.S. DEPARTMENT OF COMMERCE. www.doc.gov

VEDOVELlO, C. (2000). Aspectos Relevantes de Parques Tecnológicos e Incubadoras de Empresas. Revista do BNDES, Rio de Janeiro, v.7, n.14, pg.273-300, dezembro. 
Walcott, S.M. (1998). High Tech in the Deep South: Biomedical Firm Clusters in Metropolitan Atlanta. University of Kentucky.

$\underline{\text { www.equipamentomedico.com.br }}$

$\underline{\text { www.hospitalar.com.br }}$

www.peb.ufrj.br 